\title{
A Molecular View of Kinetochore Assembly and Function
}

\author{
Andrea Musacchio ${ }^{1,2, *}$ and Arshad Desai ${ }^{3,4, *}$ \\ 1 Department of Mechanistic Cell Biology, Max Planck Institute of Molecular Physiology, Otto-Hahn Straße 11, \\ Dortmund 44227, Germany \\ 2 Centre for Medical Biotechnology, Faculty of Biology, University Duisburg-Essen, Essen 45117, Germany \\ 3 Ludwig Institute for Cancer Research, La Jolla, CA 92093, USA \\ 4 Department of Cellular \& Molecular Medicine, 9500 Gilman Dr., La Jolla, CA 92093, USA \\ * Correspondence: andrea.musacchio@mpi-dortmund.mpg.de (A.M.); abdesai@ucsd.edu (A.D.); \\ Tel.: +49-231-133-2101 (A.M.); +1-858-534-9698 (A.D.); Fax: +49-231-133-2199 (A.M.)
}

Academic Editor: J. Richard McIntosh

Received: 13 December 2016; Accepted: 17 January 2017; Published: 24 January 2017

\begin{abstract}
Kinetochores are large protein assemblies that connect chromosomes to microtubules of the mitotic and meiotic spindles in order to distribute the replicated genome from a mother cell to its daughters. Kinetochores also control feedback mechanisms responsible for the correction of incorrect microtubule attachments, and for the coordination of chromosome attachment with cell cycle progression. Finally, kinetochores contribute to their own preservation, across generations, at the specific chromosomal loci devoted to host them, the centromeres. They achieve this in most species by exploiting an epigenetic, DNA-sequence-independent mechanism; notable exceptions are budding yeasts where a specific sequence is associated with centromere function. In the last 15 years, extensive progress in the elucidation of the composition of the kinetochore and the identification of various physical and functional modules within its substructure has led to a much deeper molecular understanding of kinetochore organization and the origins of its functional output. Here, we provide a broad summary of this progress, focusing primarily on kinetochores of humans and budding yeast, while highlighting work from other models, and present important unresolved questions for future studies.
\end{abstract}

Keywords: centromere; kinetochore; cell division; mitosis; meiosis; KMN; CCAN; CENP-A

\section{An Overview of Kinetochore Structure and Functions}

In eukaryotes, the kinetochore is a proteinaceous multi-subunit assembly whose main function is to generate load-bearing attachments of sister chromatids (the replicated chromosomes held together by the protein complex cohesin) to spindle microtubules during cell division (mitosis or meiosis) (Figure 1A). Kinetochores couple sister chromatids to dynamic microtubules during congression and anaphase, allowing their separation and partition to the daughter cells [1-3].

Kinetochores assemble on a specialized chromatin locus named the centromere (which, when large enough to be observed, coincides with the primary constriction on chromosome spreads in karyotype analysis) [4-6]. Even if the name 'centromere' implies a position at the center of the chromosome, centromeres in different organisms can occupy very different positions, and are generally defined as metacentric (if they are in the middle of the chromosome), acrocentric (if they separate chromosome arms of different length), or telocentric (if they are positioned very close to a chromosome's end). In organisms, such as nematodes, several insects, and lower plants, centromeres extend along the entire length of the chromosome (so-called holocentric centromeres, in opposition to spatially delimited monocentric centromeres). The size of the chromosome segment required to assemble a functional 
kinetochore varies wildly from species to species, from $~ 125$ base pairs (bps) in Saccharomyces cerevisiae to one or more million bps in humans. Most centromeres are defined by a specific chromatin signature rather than a specific DNA sequence (with notable exceptions discussed in Section 2). This property is generally referred to as epigenetic specification of centromeres [4-6]. Despite the considerable compositional and positional variety of centromeres, a common molecular architecture is clearly discernible in kinetochores across the eukaryotic world, with the significant known exception of kinetoplastids (see Section 8).

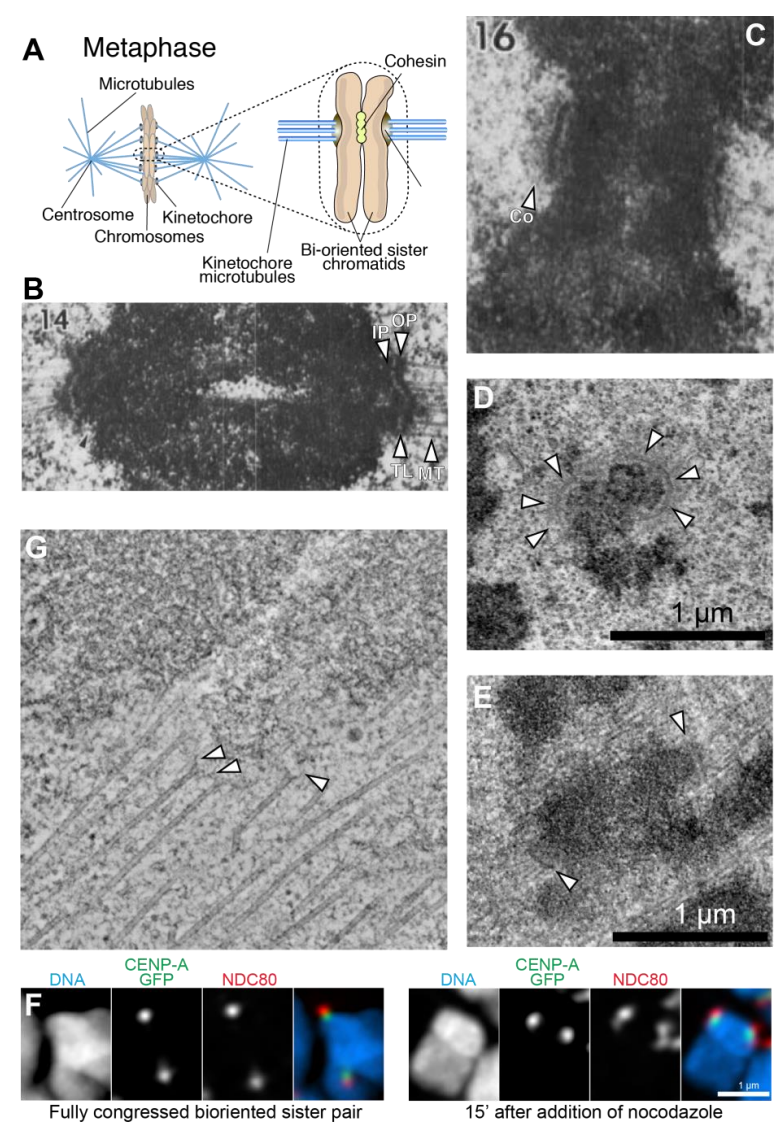

Figure 1. Kinetochore morphology in vertebrate cells (A) Schematic showing the attachment of chromosomes to spindle microtubules through kinetochores; (B) Early work on the kinetochore identified inner and outer plates, separated by a translucent layer. Microtubules terminate end-on on the kinetochore outer plate. Arrowheads indicate inner plate (IP), outer plate (OP), translucent layer (TL), and kinetochore microtubules (MT). Image reproduced with permission from reference [7]; (C) The corona ( $\mathrm{Co}$ ) is a fibrous structure that is more clearly visible on kinetochores prior to microtubule attachment. Image reproduced with permission from reference [7]; (D,E) Prior to microtubule attachment (D), vertebrate kinetochores adopt a crescent-like shape. The latter is not visible on fully congressed and bi-oriented kinetochores. Images courtesy of Alexey Khodjakov. See also reference [8]; (F) Left: at metaphase, the distributions of two proteins in the inner and outer kinetochores (NDC80 and CENP-A respectively), are similar; Right: After treatment with a microtubule-depolymerizing drug (nocodazole), proteins in the corona (not shown) and in the outer kinetochore undergo an expansion and form the crescent-like shape already shown in D. Image courtesy of Alexey Khodjakov. See also reference [8]; (G) A prometaphase PtK2 cell prepared for electron microscopy by high-pressure freezing and freeze-substitution in glutaraldehyde and Osmium tetroxide. The cell was then embedded in plastic, serial-sectioned with $300 \mathrm{~nm}$ sections, and imaged by serial tilting. A 3D reconstruction was computed by back-projection, using the IMOD software package. The slice shown here is about $5 \mathrm{~nm}$ thick, and represents the average of two consecutive tomographic planes. Arrowheads indicate slender fibrils connecting the end of microtubules to the kinetochore. Image courtesy of J. Richard McIntosh. 
Besides mediating interactions with spindle microtubules, kinetochores are mechanosensors that control stability of microtubule attachment to favor the bi-orientation of sister chromatids (or of the bivalents during meiosis), instead of incomplete or incorrect configurations such as mono-orientation, syntelic attachment, or merotelic attachment [9]. This property of kinetochores is generally referred to as error correction, and its molecular basis remains rather poorly understood. The pioneering experiments of Nicklas and colleagues [10], as well as more recent functional analyses [11-13], suggest that the development of tension within the kinetochore or between sister kinetochores contributes to discerning correct attachment from incorrect ones (see chapter by Lampson and Grishchuk, reference [14]). Kinetochores also regulate the spindle assembly checkpoint (SAC, also named the metaphase checkpoint), a feedback mechanism required to couple the initiation of mitotic exit with the completion of sister chromatid bi-orientation $[15,16]$. The trigger of mitotic exit is the inactivation of mitotic Cyclin-dependent kinase (CDK) activity and the activation of the protease activity that eliminates sister chromatid cohesion. Both processes are regulated by Ubiquitin-dependent proteolysis, and the SAC inhibits this regulated proteolysis to prevent premature mitotic exit in presence of unattached or improperly attached kinetochores (see chapter by Ajit Joglekar, reference [17]). There is overlap between the functions of the SAC as a mechanism to gain time when chromosome attachment is incomplete or erroneous, and the function of the error correction apparatus that aims to favor bi-orientation. Indeed, common molecular machinery regulates these processes, at least at the apex of the pathway.

The ultrastructure of the vertebrate kinetochore is described based on early electron microscopy (EM) studies employing glutaraldehyde fixation that identified kinetochores as trilaminar structures, approximately $250 \mathrm{~nm}$ wide and $80 \mathrm{~nm}$ deep, with an electron-opaque inner plate juxtaposed to the centromeric chromatin, a translucent gap layer, and an electron-opaque, chromatin-distal outer plate apparently embedding the plus ends of spindle microtubules (defined as end-on attachment, Figure 1B) $[7,18]$. Furthermore, in the absence of microtubules, a fibrous structure named the corona becomes apparent externally to the outer plate [19-23] (Figure 1C). The corona, which is not morphologically discernable following microtubule binding, triggers a significant expansion of the kinetochore in a crescent-like shape [7,8,24-26] (Figure 1D,E). Studies with improved fixation (high pressure freezing followed by freeze substitution) failed to confirm the existence of a clearly defined trilaminar plate structure in the kinetochore, and have rather redefined the kinetochore as a disordered fibrous mesh in which the plus ends of microtubules are embedded $[8,27,28]$. Depolymerizing protofilaments of microtubules were shown to establish connections to the kinetochore through slender fibrils [29] (Figure 1F).

A significant limitation in our understanding of kinetochores until the early 2000s was that a molecular description of their architecture was largely missing. The advent of mass spectrometry-based proteomics and functional genomics has led to substantial progress in the identification of kinetochore subunits and sub-complexes, their reconstitution and purification, and their structural characterization at high-resolution by X-ray crystallography and EM [3]. In particular, the structure of most of the components of the outer kinetochore is now known, or can be inferred through cross-linking experiments, and parts of the inner kinetochore are also beginning to be characterized. Below, we first present a brief summary of studies on the centromere and its epigenetic definition. We then review progress toward defining the structural organization of kinetochores, with references to older foundational work and to accompanying chapters in this issue that focus on the functional output of kinetochores, including microtubule-dependent force generation, error correction, and the SAC (see references $[14,17,30])$. In our discussion of kinetochore structural organization, we will focus on human kinetochores and lessons from recent biochemical reconstitution efforts but will refer to work in other models to highlight important parallels/differences, and also to present questions that emerge from cross-model comparisons. 


\section{The Centromere}

As discussed in the previous section, the centromere is the specialized chromatin region on which kinetochores assemble. The DNA sequence at the centromere, however, varies considerably from organism to organism. The short cis-acting DNA segments of S. cerevisiae centromeres (usually designated as CENs) have overall conserved sequence features among the 16 chromosomes and are sufficient for kinetochore assembly [31-35]. This type of centromere, found in S. cerevisiae and related fungi, is referred to as a point centromere [36] (Figure 2A-C). The complexity of centromeres in most other organisms, however, vastly exceeds that of the $S$. cerevisiae centromere. In the majority of model systems studied to date, centromeres consist of highly repetitive DNA elements, including retro-transposons or tandem repeat arrays, or combinations of both $[4,6,37]$. These centromeres span chromosome regions in a range from tens of thousands to millions bps, and have therefore been defined as regional centromeres [36]. For instance, human centromeres consist of a large number of tandem 171-bps repeats, called $\alpha$-satellite repeats, which extend within domains of $\sim 0.2-4.0 \mathrm{Mbps}$ [38] (Figure 2D-F). Tandem repetitive sequences, unrelated to those in humans, are also identified at centromeres of mice, fission yeast, flies, and plants, among others $[4,6,37]$. These complex regional centromeres have a central portion where the kinetochore is assembled, flanked by pericentromeric regions that are often also repetitive, heterochromatic in nature and accumulate cohesin complexes.

In contrast to $S$. cerevisiae, it has not been possible to identify, in these larger and more complex centromeres, a univocal relation between the underlying sequence of the centromere and the ability to seed a kinetochore [4,6,37]. For instance, conversion of a non-functional centromere to a functional one on mini-chromosomes can occur in the absence of apparent sequence, structural, or chemical changes in S. pombe [39]. Stably inherited dicentric chromosomes (chromosomes with two distinct repeat arrays normally associated with centromere function) invariably show inactivation of one of the two predicted centromeres, indicating that the DNA sequence is insufficient to establish the kinetochore $[40,41]$. On the same line, functional neo-centromeres can form at euchromatic regions of human supernumerary marker chromosomes in the absence of alphoid DNA [42-44], showing that repetitive DNA is not necessary for a functional centromere. Similarly, acentric (i.e., centromere lacking) chromosome fragments produced by irradiation can be transmitted quite faithfully in $D$. melanogaster cells because they acquire neo-centromere activity at non-repetitive sequences [45]. That the presence of repetitive sequences is not an absolute requirement for centromere identity is also supported by the observation that centromeres of several organisms are devoid of them [46-50]. Repetitive sequences, however, are likely to contribute to the stabilization of centromere organization and function. Evolutionarily new centromeres (ENCs), which are initially generated by centromere repositioning in non-repetitive, "gene desert" regions of the genome without additional chromosomal changes, re-acquire repetitive DNA sequences in short evolutionary times [51-53].

Collectively, the observations discussed in the previous paragraph provided the foundation for the idea that centromeres in most organisms are defined epigenetically rather than through specific DNA sequences [54-56]. Over the years, the search for crucial determinants of epigenetic specification of centromere identity has narrowed to CENP-A (also called CenH3) $[57,58]$. CENP-A is a histone $\mathrm{H} 3$ variant [59-61] (Figure 3A). (Specific features of CENP-A that distinguish it from canonical H3 are discussed in Section 2.) With some exceptions [62], CENP-A is present at functional centromeres, from S. cerevisiae (where it is called Cse4) to humans [61,63,64]. CENP-A is required for kinetochore recruitment of all other kinetochore components [65-69], and is sufficient to promote kinetochore assembly when targeted artificially to ectopic locations [70-76].

While the association of CENP-A, a crucial epigenetic factor, with the sequence-specific yeast centromere may seem counterintuitive, it is important to note that CENP-A not only serves as an epigenetic mark but also functions as the foundation for kinetochore assembly (as discussed in

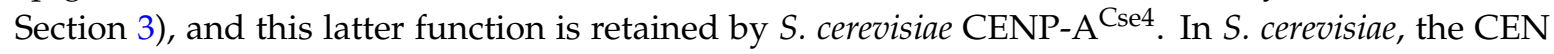
DNA-binding CBF3 complex helps target $\mathrm{CENP}^{\mathrm{A}} \mathrm{A}^{\mathrm{Cse}}$, making propagation of CENP-A nucleosomes genetically specified and restricted to a specific location. The concept of epigenetic specification 
in other species relates to the fact that the presence of CENP-A on a defined segment of DNA is (largely) sequence independent, yet extremely stable and self-propagating at that particular locus (the centromere) through multiple cell generations. The molecular basis for this phenomenon is discussed in Section 7.
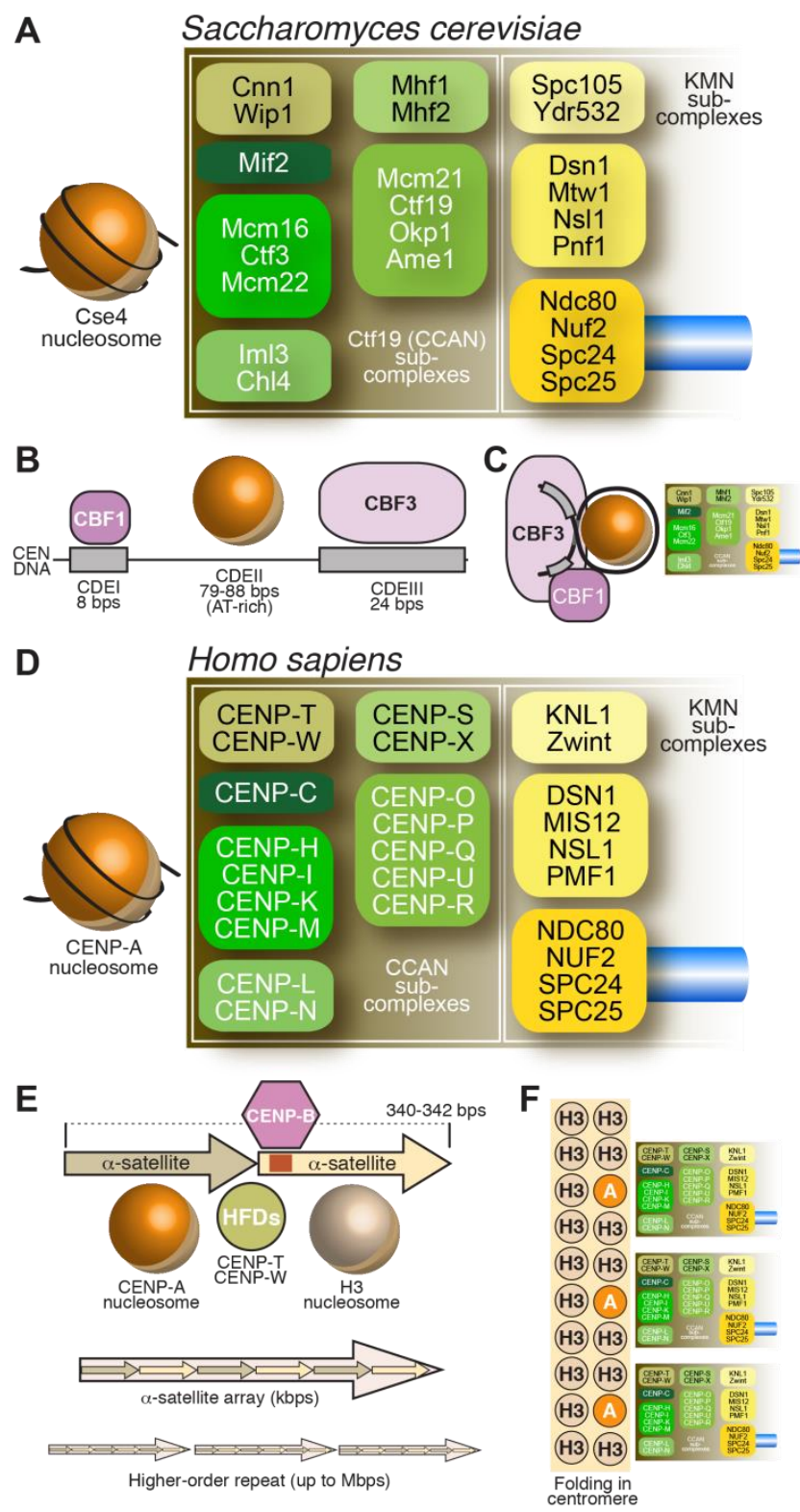

Figure 2. Schematic summary of the structural organization of budding yeast and human kinetochores. Related colors highlight conserved components/complexes. (A) Schematic of the S. cerevisiae kinetochore with subunit names; (B) The S. cerevisiae centromere (CEN) DNA is stereotyped and contains CDEI,


CEN DNA around a Cse4 nucleosome brings CBF1 and CBF3 in close proximity; (D) Schematic of the H. sapiens kinetochore. Orthologous complexes are shown in the same order as in (A); (E) The unit of human centromere assembly may consist of a pair of $\alpha$-satellite repeats, each precisely wrapping around a nucleosome. One of the two $\alpha$-satellite repeats carries a CENP-B box. The CENP-TW complex may interact in the inter-nucleosomal region through its histone-fold domain (HFDs) [77,78]. Repeats of this unit give rise to $\alpha$-satellite arrays, which in turn may organize themselves in higher order repeats (HORs); (F) The human centromere arises from folding of centromeric chromatin in three dimensions to facilitate the participation of several CENP-A nucleosomes in kinetochore assembly. 
A

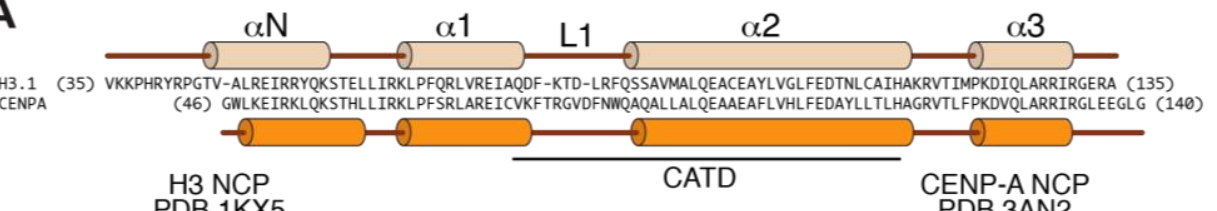

PDB 1 KX5

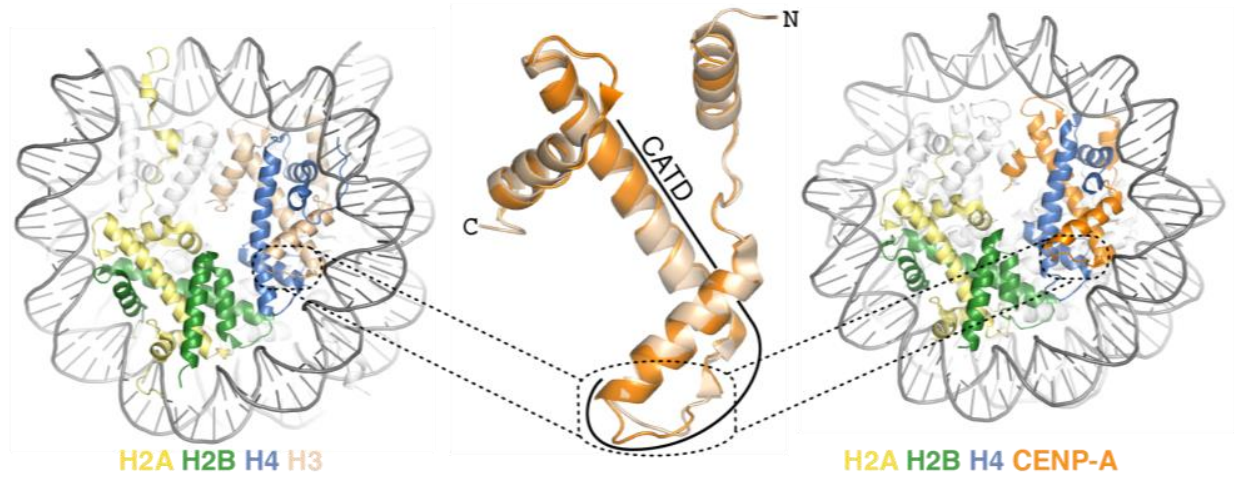

B

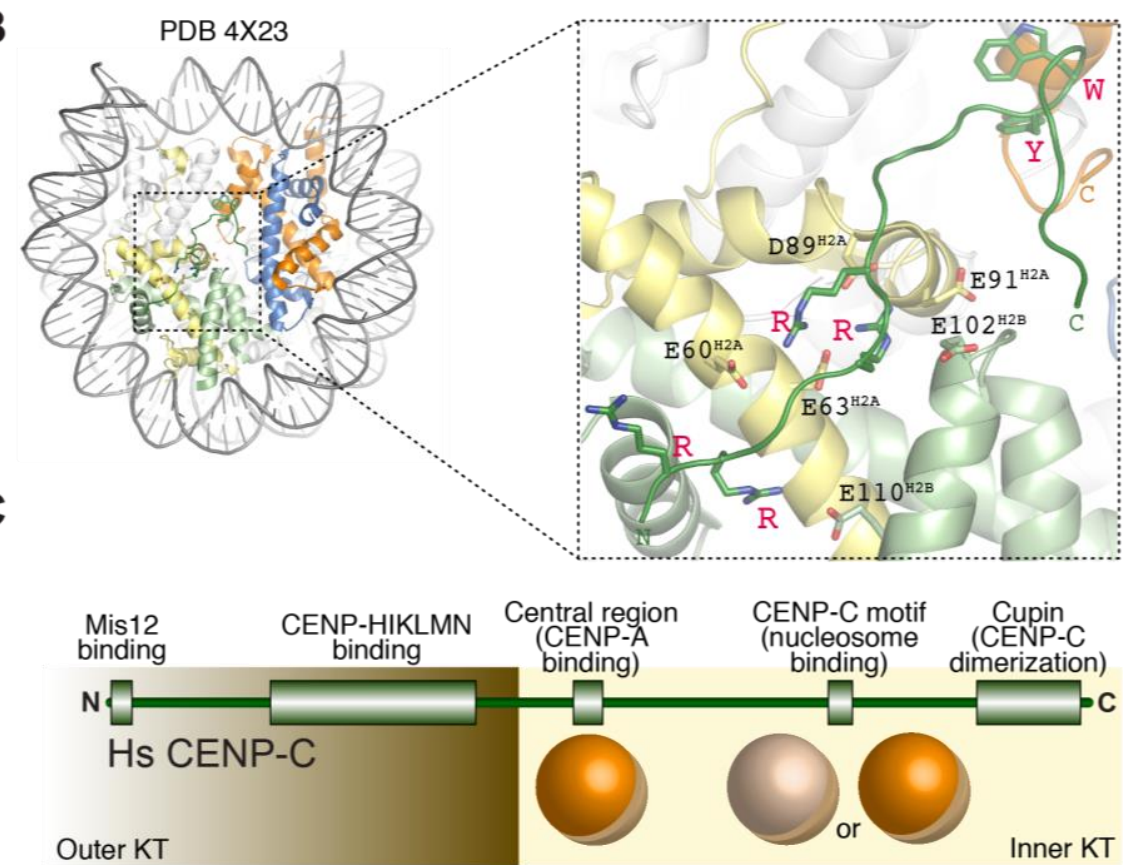

516-TVTKSRRISRRPSDWWVVKSEE-537

CENP-C motif Hs 736-NVRRTKRTRLKPLEYWRGERIDY-758

Figure 3. The CENP-A nucleosome and its specific recognition by CENP-C. (A) Comparison of H3 and CENP-A primary, secondary, tertiary, and quaternary structure. Sequence and structure changes concentrate in the N-terminal region, in the L1 segment of the CATD, and in the C-terminal region; (B) Structure of the complex of the CENP-C motif bound to a nucleosome containing a chimeric histone H3 with grafted hydrophobic C-terminal peptide of CENP-A [79]; (C) Scheme illustrating the organization of CENP-C as a "blueprint" for kinetochore assembly along the outer to inner kinetochore axis [80]. The $\mathrm{H3}$ nucleosome structure is from X. laevis, the CENP-A nucleosome structure is human, and the CENP-C motif-bound structure has a Drosophila nucleosome core particle (in which the human CENP-A tail was grafted onto H3) bound to a rat CENP-C motif.

Why do centromeres in most species rely on an epigenetic identity and vary so significantly in sequence despite their essential role in cell division? And why do active centromeres accumulate repetitive DNA sequences? While definitive answers to these questions remain to be obtained, some current hypotheses are mentioned here in brief. With regards to the first question, the 'centromere drive' 
hypothesis posits that asymmetry of chromosome segregation in oocytes, where only a quarter of the genome is transmitted to the egg while the rest is discarded in polar bodies, leads to a genetic conflict that drives rapid centromere evolution [81]. This hypothesis has received support from evidence of adaptive evolution in centromere/kinetochore proteins $[82,83]$ and from analysis of centromere activity in mouse strains with variation in centromeric repeats [84]. A different but not mutually exclusive idea is that the foundation for kinetochore assembly requires a chromatin state that is defined largely by architectural instead of sequence constraints, thereby reducing selection pressure to maintain specific sequences. Provided that this chromatin architecture can be inherited through division, such a model would explain centromere variation also in species that lack asymmetric segregation during meiosis. For the question regarding presence of repeats at centromeres, neocentromeres lacking repeats have been shown to be more sensitive to missegregation and to localize lower amounts of the error correction machinery [85], implicating repeats in segregation accuracy. One hypothesis, based on studies in S. pombe $[86,87]$ is that repetitive sequences trigger heterochromatin formation, which in turn promotes cohesin complex enrichment that both mechanically strengthens the centromere and promotes localization of error correction machinery. Such a model would link optimal centromere functionality to repeat accumulation, potentially accounting for why repeats have independently accrued at centromeres of divergent species.

\section{The Inner Kinetochore}

\subsection{The CCAN}

Despite considerable diversity of centromere organization in different organisms, kinetochores share significant similarity in their biochemical composition in evolution $[88,89]$. Early inroads into the identification of proteins present at kinetochores were made when sera from patients diagnosed with the autoimmune syndrome CREST (Calcinosis, Reynaud's syndrome, Esophaegal dysmotility, Sclerodactyly, Telangiectasia) detected centromeres in cells [90]. Subsequent work with these anti-centromere antibodies (ACA) let to the identification of three antigens, which were named CENP-A, CENP-B, and CENP-C, where CENP stands for centromeric protein [57,58]. Subsequent work led to the identification of the coding sequence of the polypeptides to which these antigens belonged $[61,91,92]$. In the following years, additional human CENPs were identified, including CENP-H and CENP-I, the latter related to a previously identified fission yeast protein, Mis6 [93-95]. Subsequent analyses of the CENP-A, CENP-H, and CENP-I associated proteomes in vertebrate cells led to the identification of several new CENPs, including CENP-K, CENP-L, CENP-M, CENP-N, CENP-O, CENP-P, CENP-Q, CENP-R, CENP-S, CENP-T, CENP-U (also known as CENP-50), CENP-W, and CENP-X [96-101]. This set of CENPs is now collectively identified as constitutive centromere associated network (CCAN), a name emphasizing localization of at least a subset of CCAN subunits at centromeres throughout the cell cycle $[100,102]$. The CCAN proteins localize to the most chromatin-proximal region of the kinetochore [103-106] (Figure 2D).

Biochemical reconstitution and reciprocal dependency for kinetochore recruitment indicate that the majority of the CCAN assembly can be subdivided into 4 discrete entities (Figure 2D): the CENP-LN complex [107-110], the CENP-HIKM complex [80,110-115], the CENP-OPQRU complex [100,115,116] and the CENP-TWSX complex $[100,101]$. These CCAN sub-complexes are probably constitutive, i.e., the stability of their subunits depends critically on reciprocal interactions in their cognate complex. These building blocks further interact as discussed later in this section.

Most of the CCAN subunits have orthologs in S. cerevisiae [107,114,115,117-119], which are collectively identified as the Ctf19 complex (Figure 2A). A notable exception is the 4-subunit CBF3 complex (Figure 2B,C), a cognate binding partner of the CEN DNA of S. cerevisiae [34]. CEN DNA contains three major regions of sequence similarity, named CDEI, CDEII, and CDEIII [35]. CDEII, which has an AT content of $\sim 90 \%$, is the binding site for the CENP-A ${ }^{\text {Cse4 }}$ nucleosome (discussed in more detail in Subsection 3.2) [120-122], whereas CDEI and CDEIII bind respectively to the general 
transcription factor Cbf1 and to CBF3 [34,123-125]. Furthermore, CBF3 and Cbf1 interact, establishing a bridge between CDEI and CDEIII that contains the CENP-A ${ }^{\mathrm{Cse} 4}$ nucleosome [126-129]. While the CENP-A $\mathrm{A}^{\mathrm{Cse} 4}$ nucleosome may be intrinsically left-handed (see Section 3.2), it has been proposed that CBF3 may configure a right-handed DNA loop [130-132].

Surprisingly, CCAN subunits, with the notable exception of CENP-C, have not been found to date in certain lineages, e.g., in D. melanogaster or C. elegans and related species [133]. This apparent loss in species that rely on CENP-A-based kinetochores for chromosome segregation, together with variation in the phenotypic impact of removal of CCAN subunits in species where they are present, highlights that much still remains to be understood about the structural and functional contributions of these four CCAN complexes at the kinetochore.

\subsection{Structural Organization of the CENP-A Nucleosome}

CENP-A retains several properties of histone H3 (Figure 3A). It interacts tightly with histone $\mathrm{H} 4$, and is incorporated in vitro and in vivo into canonical octameric nucleosomes with histones $\mathrm{H} 2 \mathrm{~A}$ and $\mathrm{H} 2 \mathrm{~B}$ that share many structural features of the canonical $\mathrm{H} 3$-containing nucleosomes, including a left-handed DNA writhe [79,134-144]. CENP-A nucleosomes have looser terminal contacts in comparison to H3 nucleosomes and protect a shorter DNA core ( 100-120 bps) in nuclease protection assays, a property enhanced by CENP-C binding [77,120,136,141,145-147].

Alternative models for the organization of CENP-A-containing nucleosomes have been proposed in recent years, and readers are referred to comprehensive recent discussions [148,149]. Given the importance that direct recognition of CENP-A plays in kinetochore assembly and stability, understanding the effective organization of the CENP-A nucleosome and its dynamic changes during the cell cycle is of great importance. To date, successful in vitro reconstitution of physical interaction of inner kinetochore proteins with CENP-A has been limited to octameric nucleosomes [79,110,141,150,151]. These high-affinity interactions occur at thermodynamic equilibrium and may account for the remarkable long-term stability of CENP-A in chromatin in vivo [141,152,153]. Thus, thermodynamic stability is a benchmark against which alternative models for the role of CENP-A in kinetochore assembly will have to be tested. This consideration does not detract from the possibility that structural changes in the organization of the CENP-A nucleosome occur during the cell cycle (e.g., during DNA replication) [148].

\subsection{Recognition of CENP-A by CCAN Subunits}

So far, two CCAN subunits, CENP-C and CENP-N (Figure 2D), have been found to interact directly with CENP-A and exhibits specificity for CENP-A versus H3 nucleosomes [76,79,110,140,150,151]. CENP-N binds directly to the CENP-A centromere-targeting domain (CATD, Figure 3A) of CENP-A [150]. The CATD comprises residues in the $\alpha 1-\alpha 2$ (L1) loop and the $\alpha 2$ helix of CENP-A and harbors the highest concentration of sequence differences between CENP-A and $\mathrm{H} 3$, with a preponderance of these in the L1 loop, which is also the only solvent-exposed region of the CATD (Figure 3A). The CATD is required for incorporation in centromeric chromatin, and is also sufficient, when grafted onto the equivalent position of $\mathrm{H} 3$, for loading of the $\mathrm{H} 3$ chimera to centromeres $[135,139]$. The latter property likely reflects a second requirement of the CATD (besides CENP-N binding), the interaction with a specific CENP-A chaperone required for incorporation of CENP-A into chromatin (see Section 7).

CENP-C, on the other hand, interacts with the acidic patch of H2A and H2B as well as with the divergent C-terminal tail of CENP-A $[76,79,140,154]$ (Figure 3B). Two sequence-related regions of CENP-C, the central region and the CENP-C motif, have been implicated, each on its own right, in the interaction with the CENP-A nucleosome (Figure 3C) [79]. The central region and the CENP-C motif each encompass $\sim 25$ residues, and contain several conserved positively charged residues near their N-terminus and two aromatic residues near their C-terminus. The N-terminal positively charged region interacts with the acidic patch of $\mathrm{H} 2 \mathrm{~A}$ and $\mathrm{H} 2 \mathrm{~B}$ on the CENP-A nucleosome, a region that has been implicated in the interaction of canonical H3 nucleosomes with different target proteins [155-157]. 
The aromatic residues, on the other hand, interact with the C-terminal tail of CENP-A, which is known to be necessary for CENP-C binding $[69,70,76,151,154,158]$ (Figure 3C). Despite relatively modest evolutionary sequence conservation, a common trait of the CENP-A C-terminal tail is that its sequence is considerably more hydrophobic than that of H3 (Leu-Glu-Glu-Gly-Leu-Gly and Glu-Arg-Ala in human CENP-A versus H3, respectively, Figure 3A). Thus, rather than a specific amino acid sequence, the higher hydrophobicity of the C-terminal tail of CENP-A may be key for specific recognition by CENP-C [79].

Despite their being related in sequence, the central region and the CENP-C motif of CENP-C do not have the same potential for kinetochore recruitment. The central region is necessary and sufficient to promote CENP-A nucleosome binding in vitro and kinetochore targeting in vivo [79,151,159-166]. The CENP-C motif, on the other hand, is insufficient for kinetochore targeting, but can be recruited to kinetochores as part of a larger C-terminal fragment capable of homo-dimerization with endogenous CENP-C through a C-terminal 'Mif2-homology' cupin-like domain [162-164,167,168]. Furthermore, while not sufficient for centromere recruitment in the absence of endogenous CENP-C, the CENP-C motif and the dimerization domain contribute to the robustness of CENP-C recruitment to kinetochores $[151,165]$.

In vitro, CENP-C and CENP-N show relatively modest selectivity for CENP-A over H3, with differences in dissociation constant of between 5- and 10-fold [110,151]. It is unlikely that these differences, in the absence of other factors, account for the exquisite selectivity of kinetochore targeting of these proteins to CENP-A nucleosomes, which are greatly outnumbered by H3 nucleosomes at centromeres and in the rest of the genome [169]. Dimerization of CENP-C through its C-terminal cupin-like domain (Figure 3C) suggests a role for multi-valency as a source of additional selectivity for the interaction of CENP-C with centromeric CENP-A nucleosomes [79]. A second source of selectivity may derive from the interaction, within the CCAN of CENP-C and CENP-N, which recognize distinct features of the CENP-A nucleosome [110,151]. Post-translational modifications of histones have also been implicated as a potential factor in the selective recognition of CENP-A nucleosomes [170,171].

In addition to CENP-C and CENP-N, the CENP-HIKM complex (Figure 2D) also contributes to CENP-A binding affinity, but this complex interacts equally well with CENP-A and H3 nucleosomes, and with linear DNA [110]. Importantly, however, CENP-C, CENP-HIKM, and CENP-LN interact in a tight 7-subunit complex, the CENP-CHIKMLN complex [110], whose stability builds on multiple interactions of its subunits, including direct interactions of CENP-HIKM or CENP-LN with CENP-C $[2,108-110,166]$.

A comprehensive view of the structural organization of the CENP-CHIKMLN complex is currently missing. Crystal structures of the CENP-LN complex of S. cerevisiae and of human CENP-M have been obtained and negative-stain single particle EM reconstructions have been generated for CENP-HIKM $[108,111]$. CENP-M is structurally and evolutionary related to Ras family small GTPases. It has lost all signature motifs previously implicated in GTP binding and hydrolysis by small GTPases, and is therefore considered a pseudo-GTPase [111]. Biochemical reconstitution demonstrated that CENP-M is required to stabilize CENP-I, predicted to have a $\alpha$-solenoid fold of $\beta$-karyopherins [111]. No CENP-M ortholog has been identified in S. cerevisiae whereas CENP-H, -I, and -K all have orthologs in this organism (Figure 2A,D) [88].

\subsection{The CENP-TWSX Complex}

The CENP-TW and CENP-SX subcomplexes (Figure 2D) associate to form the tetrameric CENP-TWSX complex. All four subunits in this tetrameric complex possess histone fold domains. CENP-T contains additional N-terminal sequences, whose function in kinetochore assembly is discussed in Section 4. While CENP-TW and CENP-SX form stable entities in isolation and can have distinct biological functions [172-174], the tetrameric CENP-TWSX assembly was proposed to form a nucleosome-like structure flanking the CENP-A nucleosome at centromeres [175]. However, rigorous structural and functional evidence for this hypothesis is lacking. In vitro, the CENP-TWSX 
complex induces positive DNA supercoiling, contrarily to H3 and CENP-A nucleosomes (and to the isolated CENP-TW and CENP-SX complexes), which induce negative supercoiling [176]. When incubated with in vitro reconstituted H3 or CENP-A di-nucleosomes and visualized by negative-stain EM, two tetramers of CENP-TWSX bound preferentially to the $\sim 100 \mathrm{bp}$ inter-nucleosome linker DNA rather than nucleosome-bound DNA, but the limited resolution did not allow discriminating whether the two CENP-TWSX tetramers formed a nucleosome-like structure on the linker DNA; in addition, nuclease cleavage did not identify the pattern normally observed with canonical nucleosomes [176].

DNA binding by CENP-TWSX requires the histone fold domains of CENP-T and CENP-W $[100,175,176]$. No evidence of DNA sequence selectivity for these domains has been reported. In contrast to CENP-A, the pool of CENP-TW turns over relatively rapidly at centromeres, and with a cell cycle-regulated pattern, with centromere incorporation in late S-phase and G2 [177]. Incorporation of CENP-TW at the kinetochore has not been shown to require histone chaperones. Rather, in both humans and yeast, kinetochore recruitment of CENP-T ${ }^{\mathrm{Cnn} 1}$ appears to depend, in addition to DNA binding, on a direct interaction with other CCAN subunits, and in particular with the CENP-HIKM complex $[78,111,113,178]$. CENP-T recruitment is also affected by the N-terminal tail of CENP-A, in both fission yeast and humans [70,179], although the biochemical basis for this effect is to date unclear. Furthermore, ablation of either CENP-TW or CENP-SX has a distinct effect on outer kinetochore stability $[100,101,178]$. These observations detract from the hypothesis of a nucleosome-like structure flanking the CENP-A nucleosome, and rather suggest that CENP-TW binds DNA weakly and requires concomitant binding to other CCAN subunits at the inner kinetochore for its recruitment.

\subsection{The CENP-OPQRU Complex}

CENP-O, -P, -Q, -R, and -U (Figure 2D) associate into a complex [109,180]. Recruitment of CENP-OPQRU to the kinetochore requires CENP-CHIKMLN [96,97]. Loss of this complex does not affect localization of other inner kinetochore components and the functional importance of this complex at vertebrate kinetochores appears to vary in different systems [109,181,182]. A role in chromosome congression, at least partly operating through microtubule-binding sites in the CENP-Q and CENP-U subunits, as well as through recruitment of the microtubule motor CENP-E to kinetochores, has been reported [182-184]. Furthermore, CENP-U has been implicated in kinetochore recruitment of Polo-like kinase 1 (Plk1), an important regulator of kinetochore-microtubule attachments [185,186]. Thus, this complex is relatively peripheral in the organization of the CCAN in vertebrates and may contribute to chromosome segregation via recruitment of motor and kinase activities.

In budding yeast, where the CENP-O/P/Q/U/R-related complex is known as the COMA complex (for Ctf19, Okp1, Ame1 and Mcm21), two of the subunits, Ctf19 and Mcm21 (homologous to CENP-P and CENP-O, respectively), are non-essential for viability but are required for accurate segregation [187]. These subunits harbor RWD domains related to those observed in the Spc24/Spc25 subunits of the Ndc80 complex and the Knl1 C-terminus [116]. Deletion of Ctf19 or Mcm21 disrupts proper replication timing and cohesin complex accumulation in the pericentromeric region [188-190]. Interestingly, the other two subunits, Ame1 and Okp1 (homologous to CENP-U and CENP-Q, respectively) are essential for viability and Ame1 has been shown to directly interact with the Mis12 complex of the KMN network via a motif whose selective mutation is lethal [191]. These results suggest a potentially more significant role for the COMA complex in inner-outer kinetochore linkage in budding yeast than has been observed for the CENP-O/P/Q/U/R complex in vertebrates. CENP-Q is essential in mouse embryonic stem cells but not in mouse fibroblasts [181]; whether this difference in phenotype arises from a differential role in kinetochore assembly is not known. It will be important to elucidate the functions of this peripheral CCAN complex and determine the reasons for distinct effects of its loss in different systems and in different contexts within the same species. 


\subsection{CENP-B}

CENP-B, the only specific DNA binding protein at mammalian centromeres, binds to the conserved 17-bp CENP-B-box, many copies of which are disseminated in centromeric $\alpha$-satellite DNA repeats [192] (Figure 2E). CENP-B shares sequence homology with transposases encoded by the pogo family of DNA transposons [193] and appears to have arisen from them. A role of CENP-B in centromere stability has been questioned because of its limited conservation (CENP-B like proteins are thought to have arisen from transposases independently in fungi, insects and mammals), because CENP-B boxes are absent from neocentromeres, and because there are chromosomes (such as the human Y chromosome) that lack CENP-B boxes altogether. Furthermore, deletion of CENP-B in mice does not affect viability [194-196]. Nonetheless, a role for CENP-B in centromere stability is suggested by its requirement for the de novo establishment of centromeres on human artificial chromosomes built using centromere-enriched satellite DNA $[197,198]$, and from the fact that its deletion increases chromosome instability $[199,200]$. Several recent and older observations support a role of CENP-B in the stabilization of centromere structure. For instance, CENP-B appears to contribute to the phasing of CENP-A nucleosomes on centromeric DNA and to the typical unwrapping of its nucleosomal termini [146], and it increases the stability of reconstituted CENP-A nucleosomes [201], likely through a direct interaction with the N-terminal region of CENP-A [199]. Furthermore, CENP-B binds directly to CENP-C, supporting a second pathway of CENP-C recruitment in addition to that based on the interaction of CENP-C with the CENP-A C-terminal tail $[159,199]$. These interactions of CENP-B may be largely redundant with other stabilizing interactions at centromeres, but their importance is exposed following perturbation of normal CENP-A function [199].

\subsection{Summary}

This section illustrates the important concept that inner kinetochores are built by evolutionary conserved interactions of CCAN subunits with the CENP-A nucleosome. In line with the theory that centromere identity is determined epigenetically in most organisms (the notable exception being budding yeasts, where a specific sequence is recognized by the CBF3 complex to direct CENP-A loading), none of these interactions, appears to require specific DNA sequences, except for those made by CENP-B, which is not conserved even throughout vertebrates and is not essential but may contribute to kinetochore stability when present. The evolutionary presence/absence and phenotypic effect of CCAN subunit inhibitions, with the possible exception of CENP-C, are also surprisingly variable, with kinetochores of well-studied models such as C. elegans and D. melanogaster lacking the entire repertoire except for CENP-C $[62,88,89,133]$. These greatly simplified kinetochores appear to entirely rely on CENP-C being a linker between the CENP-A nucleosome and the outer kinetochore, as discussed in Section 5. This variation raises intriguing questions about the functional roles of this large group of inner kinetochore proteins that will be important to address in future studies.

\section{The Outer Kinetochore}

The outer kinetochore is the (main) platform for end-on microtubule binding by the kinetochore and responsible for transducing the force generated by depolymerizing microtubules to move chromosomes. The core of the outer kinetochore is a 10-subunit protein assembly known as KMN (for Knl1 complex, Mis12 complex, Ndc80 complex, described in Figure 2) [115,202-212]. The three sub-complexes (Kn11, Mis12, and Ndc80) exercise clearly distinct functions as summarized below.

\subsection{The Ndc80 Complex}

The 4-subunit Ndc80 complex is the primary microtubule receptor at the kinetochore $[209,213]$. Its four subunits contain large segments of coiled-coil, flanked by globular domains (Figure 4A). The complex is dumbbell-shaped and has a long axis of approximately 55 to $60 \mathrm{~nm}$ (Figure 4A,B). Microtubule-binding, mediated by the N-terminal regions of the Ndc80 and Nuf2 subunits, and 
kinetochore-targeting, mediated by the C-terminal regions of the Spc24 and Spc25 subunits, occupy opposite ends of the complex [214-218].

Crystal structures of isolated globular domains of Ndc80 complex subunits, and of engineered $\mathrm{Ndc} 80$ complexes lacking most of the coiled-coil (named $\mathrm{Ndc} 80^{\text {Bonsai }}$ and $\mathrm{Ndc} 80^{\text {Dwarf }}$ ), revealed that the microtubule-binding region of the Ndc80 complex consists of a pair of tightly packed calponin-homology (CH) domains in the Nuf2 and Ndc80 (also called Hec1) subunits [216,218,219]. The latter are structural paralogs, whose overall domain organization, an $\mathrm{N}$-terminal $\mathrm{CH}$ domain adjoined by a coiled-coil segment, is also found in three Intraflagellar Transport (IFT) complex B subunits, IFT81, IFT57, and CLUAP1 [220].

Visualization by cryo-electron microscopy of $\mathrm{Ndc} 80^{\text {Bonsai }}$ bound to microtubules demonstrated a direct interaction of the $\mathrm{CH}$ domain of the $\mathrm{Ndc} 80$ subunit with the microtubule lattice with a spacing of $4 \mathrm{~nm}$ along each protofilament, indicative of interactions of the $\mathrm{CH}$ domain with both tubulin monomers [209,221,222] (Figure 4C). The interaction engages a region of the $\mathrm{Ndc} 80 \mathrm{CH}$ domain, designated toe, which gathers several positively charged residues previously shown to mediate high-affinity microtubule binding, and which has been proposed to act as a conformational sensor for straight protofilaments [221,223].

In addition to the $\mathrm{CH}$ domains, an $~ 80$-residue, highly basic and structurally disordered $\mathrm{N}$-terminal tail of the $\mathrm{Ndc} 80$ subunit has been functionally implicated in the Ndc80-microtubule interaction in vitro and in cells $[213,216,218,224-226]$ (Figure 4A). The N-terminal tail may contain two distinct functional segments. One segment, running from residues 47-68 (of human Ndc80), has been implicated directly in microtubule binding through an interaction with E-hooks (the negatively charged C-terminal tails of $\alpha$ - and $\beta$-tubulin) of tubulin protomers in the adjacent protofilament [222]. Another segment, preceding the E-hook binding region, has been implicated in inter-Ndc 80 complex interactions along the same protofilament [221,222]. Collectively, these interactions may be responsible for the ability of the Ndc80 complex to form clusters on the microtubule lattice [218,221,222], and suggest that binding of $\mathrm{Ndc} 80$ complexes to microtubules may be cooperative. As explained more thoroughly below, however, a microtubule-binding site in the kinetochore engages a relatively small number of Ndc80 complexes (probably 6 to 10) in an end-on configuration. Whether Ndc80 complexes can interact inter-molecularly in this setting, and whether their binding to microtubules is cooperative, remains controversial [227-229]. We additionally note that deletions of the Ndc80 tail in S. cerevisiae and in C. elegans do not exhibit the severe phenotypic consequences expected for a major defect in kinetochore-microtubule interactions [230-232]; in contrast, mutations in conserved $\mathrm{CH}$ domain residues have severe consequences in all systems where they have been analyzed. Thus, the precise role of the $\mathrm{N}$-terminal tail of $\mathrm{Ndc} 80$ in kinetochore-microtubule interactions remains an important question for future investigation.

While the mechanism of the interaction of Ndc80 with microtubules and with itself requires further investigation, it is clear that the $\mathrm{N}$-terminal tail of $\mathrm{Ndc} 80$ regulates microtubule binding. Aurora B kinase, a major regulator of kinetochore-microtubule attachment [14], phosphorylates up to nine sites in the human Ndc80 N-terminal tail [213,216,218,221,222,224-226,229,233]. Phosphorylation neutralizes the intrinsic positive charge of the Ndc80 N-terminal domain, greatly decreasing the binding affinity of the Ndc80 complex for microtubules in vitro $[209,216,218,225,226]$. The N-terminal tail of C. elegans $\mathrm{Ndc} 80$ is also the target of regulation by a protein complex that recruits and activates the dynein motor at kinetochores [232]; see Section 5.3 below.

\subsection{The Mis12 and Knl1 Complexes}

The Mis12 complex is an interaction hub that promotes KMN assembly through its binding sites for both the Ndc80 complex and the Knl1 complex, and that connects the KMN with the inner kinetochore through interactions with CENP-C and CENP-T. Previous low-resolution negative stain EM analyses depicted the Mis12 complex (known as MIND complex in S. cerevisiae) as a $\sim 20 \mathrm{~nm}$ rod [234-237]. When Mis12 and Ndc80 are combined and their structure is examined by negative stain or rotary 
shadowing EM, they appear as $~ 90-n m$ particles, indicating that they interact 'in series' $[238,239]$ (Figure 4D). Recent crystal structures of the human and yeast complexes demonstrate that the four subunits of the Mis12 complex are structural paralogs with high helical content (Figure 4E). They pair in Dsn1:Ns11 and Mis12:Pmf1 sub-complexes, that meet in a central stalk domain. The N- and C-termini of all four subunits cluster at opposite ends of the rod [240,241]. Linear motifs near the C-termini of the Nsl1 and Dsn1 subunits of the Mis12 complex, invisible in the crystal structure, provide binding sites for the RWD domains in the C-terminal region of the Spc24 and Spc25 subunits of the Ndc80 complex [234,240-242].

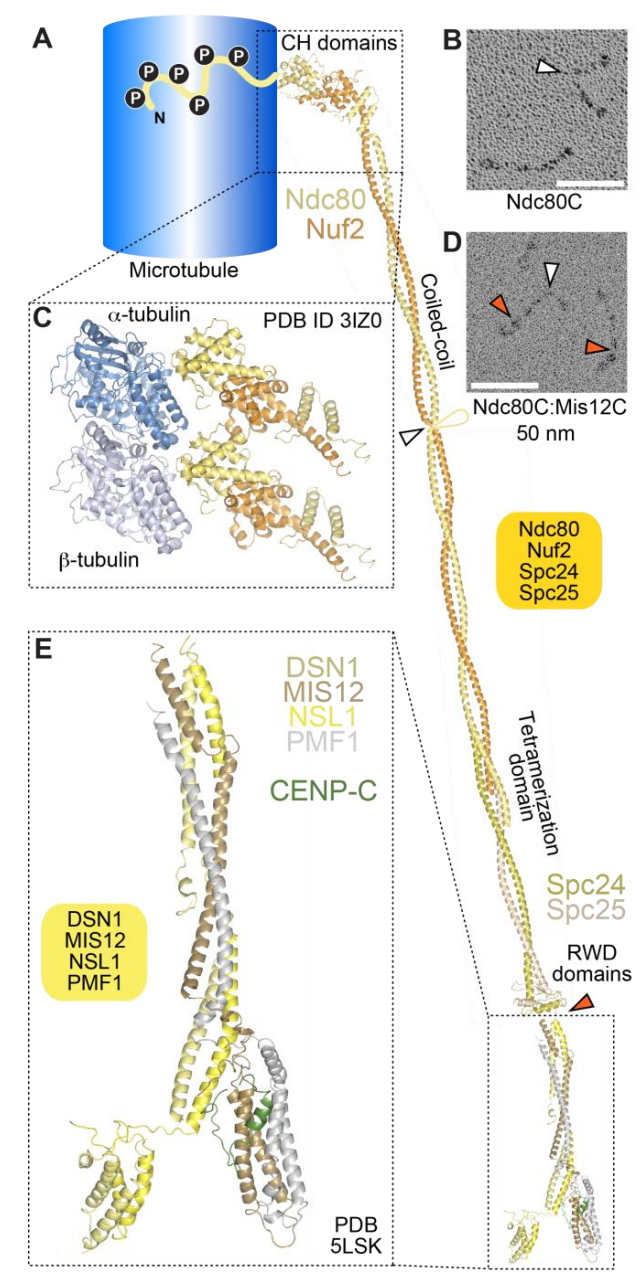

Figure 4. The NDC80 and MIS12 complexes of the KMN network. (A) The NDC80 complex is highly elongated and interacts with microtubules via calponin-homology $(\mathrm{CH})$ domains in the N-terminal regions of NDC80 and NUF2. A basic N-terminal tail preceding the NDC80 CH domain (depicted as unstructured) is subject to Aurora kinase phosphorylation (Ps in black circles) and regulates microtubule binding. A long coiled-coil, interrupted by a loop (white arrowhead) terminates in a tetramerization domain with SPC24 and SPC25. The latter start with coiled-coils and terminate with RWD domains (red arrowhead), which interact with the MIS12 complex; (B) Rotary shadowing electron microscopy of the NDC80 complex, showing its characteristic dumbbell shape, and an overall length of $\sim 65 \mathrm{~nm}$. Images in (B,D) courtesy of Dr. Pim Huis in 't Veld, Max Planck Institute of Molecular Physiology, Dortmund (Germany) [239]; (C) Model from cryo-EM studies of the Ndc80 ${ }^{\text {Bonsai }}$ complex bound to the microtubule lattice. Only a single $\alpha$-tubulin: $\beta$-tubulin dimer is shown, with two $\mathrm{Ndc} 80^{\text {Bonsai }}$ complexes bound via the toe region; (D) Complexes of the NDC $80 \mathrm{C}$ and MIS12C are $\sim 85 \mathrm{~nm}$ in length; (E) Structural organization of the MIS12 complex bound to the N-terminal region of CENP-C [241]. All structures shown are for the human complexes. 
The stalk of the Mis12 complex, together with a 20-residue C-terminal motif in Nsl1, also provides a binding site for Knl1, the largest outer kinetochore subunit (2316 residues in humans) (Figure 5). With the exception of the last $\sim 500$ residues, Knl1 is largely intrinsically disordered, and contains an array of protein docking motifs, including a canonical binding site for the PP1 phosphatase very near the N-terminus, and multiple Met-Glu-Leu-Thr (MELT) repeats, identified to act, after phosphorylation by the Mps1 kinase on the conserved Thr residue, as docking sites for the SAC protein complex Bub1:Bub3 [15,17] (Figure 5). The Knl1 C-terminal region, on the other hand, consists of a predicted coiled-coil followed by tandem RWD domains, and is therefore structurally related to Spc24, Spc25, CENP-O, and CENP-P, suggesting a common evolutionary origin of these proteins $[116,235]$. The RWD domain mediates a direct interaction of Knl1 with the Mis12 complex, whereas Zwint binds to a more extended domain additionally comprising the coiled-coil region $[234,235,241]$.

With some variations, the description of the outer kinetochore in the previous paragraphs applies to yeast and human kinetochores alike. In addition, in the case of the outer kinetochore, exceptions have emerged in the course of evolution. In D. melanogaster, for instance, no ortholog of Dsn1 or Zwint was identified, whereas two closely related and functionally redundant paralogs of Pmf1 ${ }^{\text {Nnf1 }}$ (Nnf1a and Nnf1b) exist [243-246]. Furthermore, the unconventional SNARE family member Snap29 was recently shown to localize to kinetochores and to be required for KMN assembly in this organism [247]. In biochemical reconstitutions, the Drosophila Mis12 complex is highly stable in the absence of Dsn1 (unlike the human and yeast complexes) [245,246]. Significant adaptation of the Nsl1 sequence at residues implicated in Dsn1 binding by the structures of the human and yeast Mis12 complex explain this result (not shown). In C. elegans, where the KMN components are all present and were shown to self-associate in biochemical reconstitutions, there are some notable sequence variations, e.g., C. elegans Knl1 lacks the tandem RWD domains at the C-terminus and the RWD domains of Spc24 and Spc25 appear severely diminished. Knl1 family proteins also exhibit widespread and recurrent evolution of repeats in their N-terminal region [248]. The reasons for these variations are currently unclear. Nonetheless, relative to the CCAN, KMN is broadly conserved, likely reflecting its essential involvement in microtubule attachment and scaffolding of the SAC.

\subsection{Complexity of the Kinetochore Microtubule Interfaces}

Understanding the role of $\mathrm{Ndc} 80$ complex in the generation of dynamic load-bearing attachments during chromosome congression and segregation is a primary goal of current research (see review by Asbury and colleagues, reference [30]). Classic in vitro studies demonstrated that kinetochores can hold on to a depolymerizing microtubule end [249] and, more significantly, a depolymerizing microtubule generates significant force that is capable of moving chromosomes bound via their kinetochores [250,251]. These studies inspired efforts to analyze if the Ndc80 complex, the widely conserved outer kinetochore-localized microtubule-binding complex, acts as a coupler that is able to harness the force generated by a depolymerizing microtubule end. When immobilized on beads at sufficiently high concentrations, the $\mathrm{Ndc} 80$ complex is sufficient to create load-bearing attachments to depolymerizing microtubules $[29,227,252]$. Individual, soluble Ndc80 complexes, on the other hand, are unable to track depolymerizing microtubule ends [253]. These experiments suggest that clustering on beads enables the establishment of multiple microtubule attachments, and that the latter are required for microtubule plus-end tracking during depolymerization. Clustering of multiple Ndc80 complexes at kinetochores is likely to achieve a similar effect. 


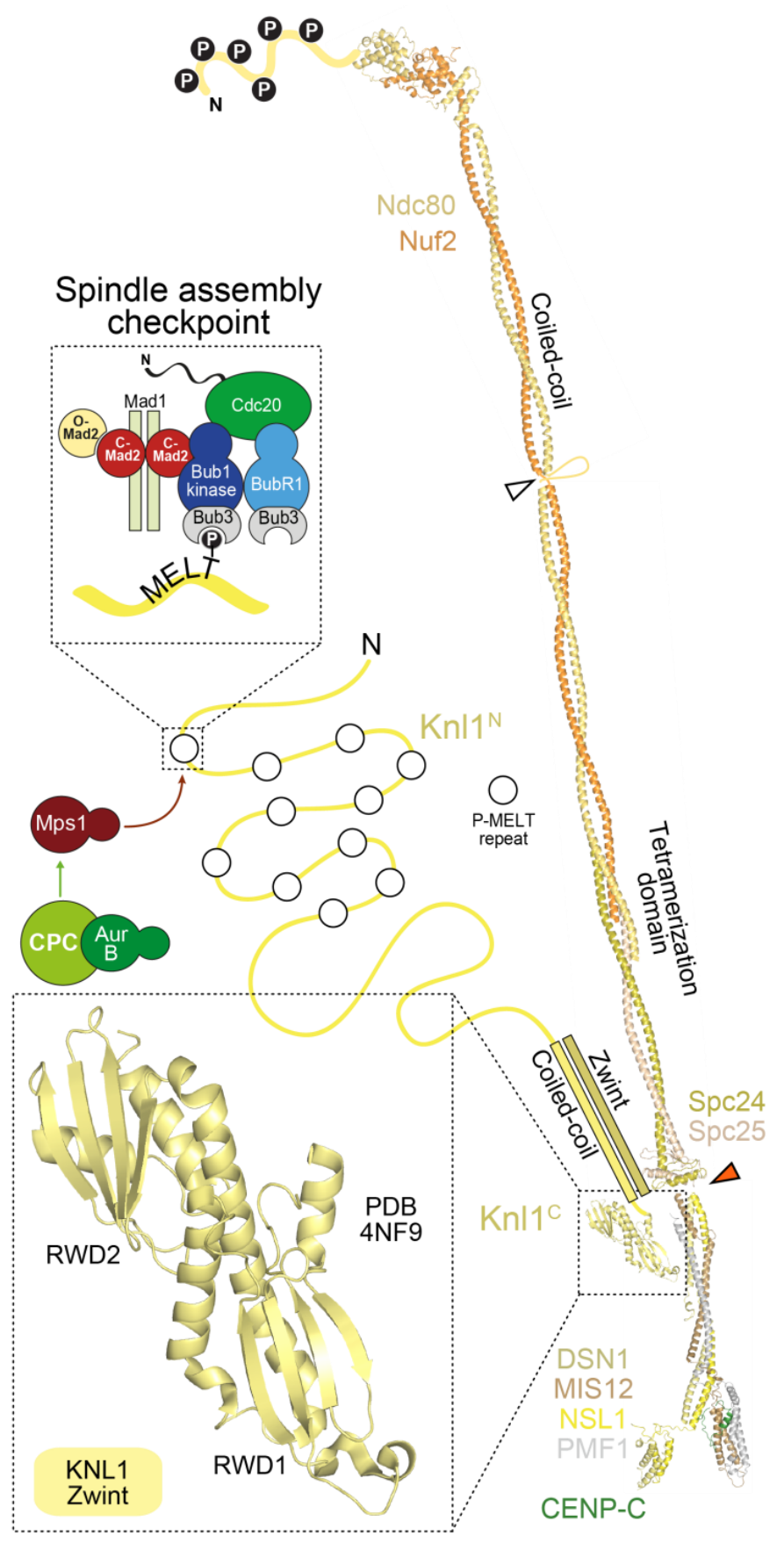

Figure 5. Orchestration of the spindle assembly checkpoint (SAC) by the KMN network SAC components are recruited via the Knl1 subunit that is 2316 residues in humans and is largely disordered. Exceptions are a predicted coiled-coil around residues 1850-2100, and the C-terminal tandem RWD domains, whose crystal structure is shown [235]. The RWD region of Knl1 binds directly to the MIS12 complex [234,235]. The N-terminal half of Knl1 contains multiple MELT repeats (Met-Glu-Leu-Thr) that are targeted by Mps1 kinase (which in turn requires Aurora B kinase to become activated). Each MELT repeat has the potential to assemble active SAC complexes that signal lack of microtubule attachment and arrest the cell cycle in mitosis.

It is important to note, however, that $\mathrm{Ndc} 80$ is not the sole player in linking kinetochores to microtubules. Additional microtubule-binding proteins and motors identified there include the SKA and Dam1 complexes, Kif18a, MCAK, SKAP:Astrin, XMAP215/CH-TOG, CENP-E, CENP-F, and Dynein $[9,254]$. The functions of these proteins at kinetochores are discussed in the essays from 
Maiato, Lampson and Grishchuk, and Asbury and colleagues ([14,30,255]), and here we limit the discussion to a brief account of the SKA and the Dam1 complexes, two sequence and structurally unrelated microtubule binders with complementary phylogenetic distributions that have emerged as playing a fundamental role in microtubule coupling at kinetochores [256-259]. The human SKA complex and the budding yeast Dam1 complex can track dynamic microtubules, and interact with their cognate Ndc80 complex specifically when bound to microtubules [253,260-265]. The Aurora B kinase phosphorylates the SKA and Dam1 complexes to reduce their binding affinity for kinetochores [264-267], in line with a regulatory scheme that identifies the Aurora B kinase as a negative regulator of the strength of the attachment of kinetochores to microtubules, and as a crucial actor in the correction of improper kinetochore-microtubule attachments (see reviews by Lampson and Grishchuk and by Asbury and colleagues [14,30]). In a recent twist, the SKA complex was also shown to stimulate Aurora B activity [268].

Structural and biochemical work on the SKA complex has started to elucidate its organization and mechanism of action [253,269-271]. The SKA complex is a trimer of the Ska1, Ska2, and Ska3 subunits. It is ' $W$ ' shaped, and consists of dimers of triple helical bundles of the three subunits [269]. The C-terminal domain of the Ska1 subunit contains a winged-helix motif that interacts with surface-exposed regions of tubulin that are insensitive to microtubule curvature, while the unstructured C-terminal region of Ska3 facilitates the interaction of Ska1 with microtubules [271]. The Dam1 complex is a heterodecamer [272,273], and individual heterodecamers assemble into rings that encircle the microtubule surface [274-277]. Both the SKA and Dam1 complexes are dependent on the Ndc80 complex for their kinetochore localization in cells and enhance the microtubule coupling ability of the Ndc80 complex in vitro. These findings suggest that the concerted action of Ndc80 and SKA/Dam1 complexes underlies the load-bearing attachments made at kinetochores but the detailed mechanistic basis for their concerted action remains to be elucidated.

\section{Linkages between the Inner and the Outer Kinetochore}

\subsection{Two Mechanisms Link Inner and Outer Kinetochores}

The outer kinetochore is linked to the inner kinetochore via two different mechanisms (Figure 6). In the first mechanism, CENP-C directly binds to the Mis12 complex [165,238,240,241,245,278,279], which in turn binds to the Ndc80 complex and Knl1. In the second mechanism, the RWD domains in the Spc24 and Spc25 subunits of the Ndc80 complex directly interact with the intrinsically disordered N-terminal extension of CENP-T [75,113,239,242,279-282]. We summarize below the detailed understanding of these two mechanisms in yeast and vertebrates and their relative importance in outer kinetochore assembly in different systems.

CENP-C (and its yeast homolog Mif2) binds directly to the Mis12 complex through an $~ 45$-residue $\mathrm{N}$-terminal motif, an interaction captured in the recent co-crystal structures of the yeast and human Mis $12^{\mathrm{MIND}}$ complexes discussed in the previous section [240,241] (Figure 4E). In S. cerevisiae, the 4-subunit COMA complex (Ctf19:Okp1:Mcm21:Ame1), which is part of the yeast CCANCtf19 complex and whose subunits are related to those in the CENP-OPQRU complex, helps reinforce the interaction of CENP-C ${ }^{\text {Mif2 }}$ with Mis12 ${ }^{\text {MIND }}$ [191]. In both yeast and humans, Aurora B kinase regulates the Mis12 ${ }^{\mathrm{MIND}}: \mathrm{CENP} \mathrm{C}^{\mathrm{Mif} 2}$ interaction by phosphorylation of two serine residues (Ser100 and Ser109 in humans) that reside in closely spaced, positively charged motifs in a disordered region of Dsn1 [280,283-287]. Aurora B phosphorylation of Dsn1 increases the binding affinity of CENP-C for the Mis12 complex by approximately two orders of magnitude, through relief of a competitive inhibitory mechanism in which the unphosphorylated Dsn1 region binds and masks in an intra-Mis12-complex manner the CENP-C binding region $[240,241]$. The significance of this regulation, which likely requires the presence of Aurora B kinase activity at centromeres, may be to stabilize the CENP-C:Mis12 complex interaction exclusively in the proximity of kinetochores. 


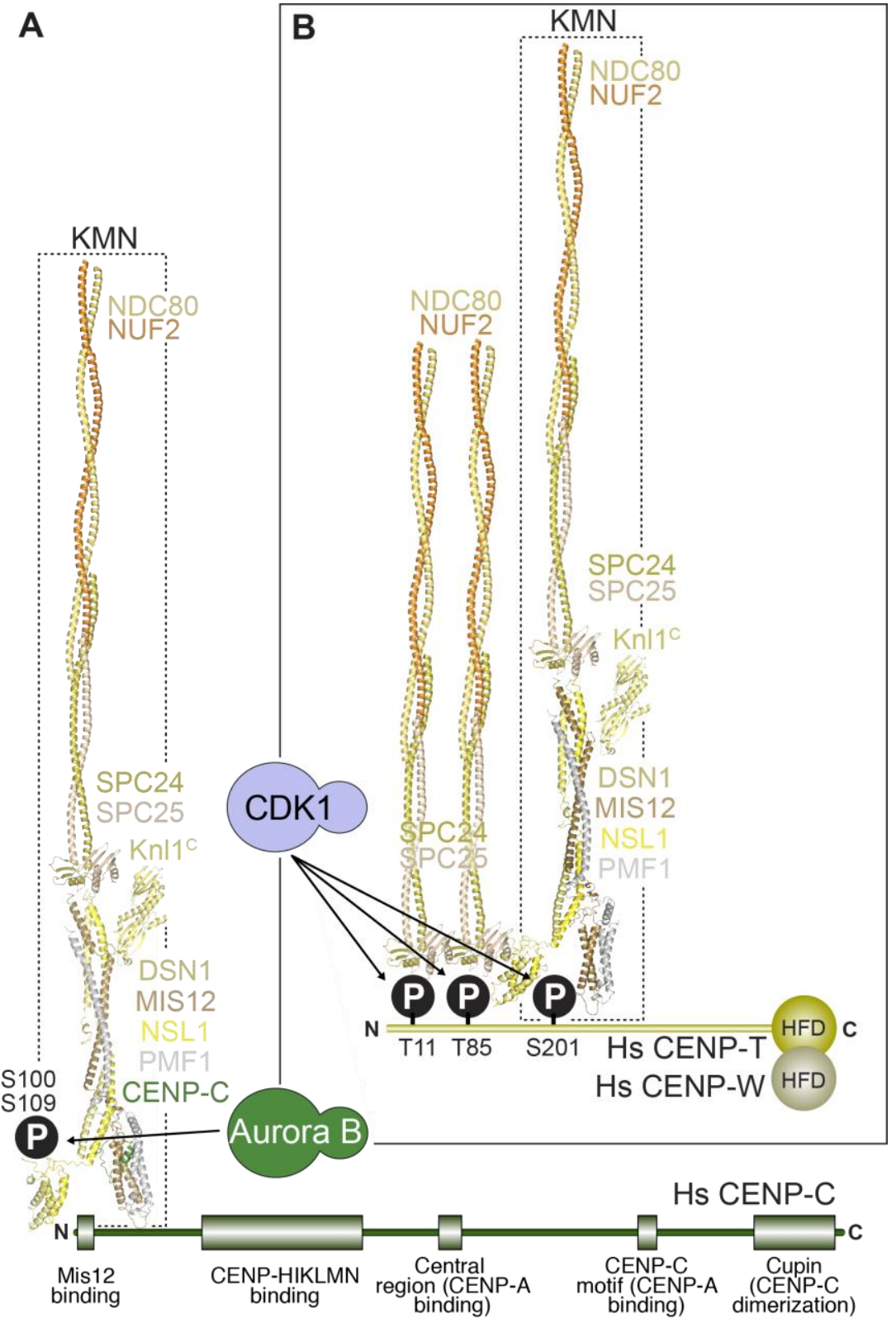

Figure 6. Linkages between the inner and outer kinetochore. Structures of a portion of the NDC80 complex (the N-terminal globular domains of NDC80 and NUF2 are not shown), the MIS12 complex and the C-terminal kinetochore-targeting domain of KNL1 are used to depict a KMN particle in humans. (A) The first linkage is formed by the interaction of a KMN particle with the N-terminal region of CENP-C. This interaction is enhanced by Aurora B phosphorylation of residues (S100 and S109) in the N-terminal region of the DSN1 subunit of the MIS12 complex; (B) The second linkage involves the interaction of up to two NDC80 complexes with two CDK1-phosphorylated residues (T11 \& T85) in the N-terminal region of CENP-T, as well as of a second entire KMN recruited via a CDK1-dependent interaction of the MIS12 complex with S201 of CENP-T [239]. In vitro, CENP-C and CENP-T bind to the MIS12 complex within the KMN network competitively, implying that they cannot be bound to the same KMN [239]. All structures shown are for the human complexes.

The RWD domains in the Spc24 and Spc25 subunits of the Ndc80 complex interact directly with two related, short sequence motifs in the first 100 residues of the intrinsically disordered N-terminal extension of CENP-T (consisting of approximately 450 residues in humans) [75,113,239,242,279-282]. In humans, this interaction requires CDK phosphorylation of the CENP-T motifs, but the equivalent interaction of 
Spc24:Spc25 with CENP-T ${ }^{\text {Cnn1 }}$ in S. cerevisiae may not require phosphorylation $[242,279,281]$. At least in vitro, the two Ndc80 complex-binding motifs of CENP-T can be occupied concomitantly, suggesting that this mechanism can recruit up to two Ndc80 complexes per CENP-T molecule $[113,239]$. The motifs on CENP-T are closely related to the Spc24:Spc25-binding motif in Dsn1 (discussed in the previous section) [242]. Not surprisingly, therefore, recent crystal structures demonstrated that the Dsn1 and CENP-T motifs bind Spc24:Spc25 through a largely similar mechanism [240].

In an interesting recent twist, it was realized that CENP-T also contributes to kinetochore recruitment of the Mis12 complex [239,280,288]. This is promoted by a direct interaction of the Mis12 complex with a distinct, non-canonical CDK phosphorylation site on human CENP-T, Ser201 [239]. Whether this interaction is conserved in S. cerevisiae is currently unknown. Thus, at human kinetochores, a single N-terminal tail of CENP-T can, after appropriate phosphorylation, promote the localization of up to three $\mathrm{Ndc} 80$ complexes, two through a direct interaction, and one indirectly through the Mis12 complex (Figure 6). These biochemical data are consistent with analysis in human cells, where CENP-T depletion reduces $\mathrm{Ndc} 80$ complex localization at kinetochores to a third of that in controls, without affecting CENP-C localization (See Section 5.2 below).

The presence of two mechanisms for linking the outer and inner kinetochore raises the question why these two linkages are needed and whether they are widely employed. In all systems tested, CENP-C inhibition leads to severe defects and lethality (with the exception of S. pombe, where a suppressor mutation can improve growth of a CENP-C null mutant that is extremely sick and missegregates chromosomes at high frequency [166]. Depletion or deletion of CENP-T results in extensive outer kinetochore assembly and chromosome alignment defects in chicken and human cells $[100,176,279,280,287,288]$. In addition, chicken CENP-T can generate ectopic microtubule attachment sites that support chromosome segregation in the absence of CENP-C [75], and a chimeric construct in which the N-terminal region of CENP-T replaced the entire N-terminal domain of CENP-C appeared to support chromosome segregation [288]. Surprisingly, however, a deletion mutant of the CENP-T ortholog Cnn1 in S. cerevisiae is viable and the absence of CENP-T does not significantly reduce the amount of Ndc80 recruited to kinetochores in this system [242,282,289]. In addition, in D. melanogaster and C. elegans, which lack all CCAN subunits with the exception of CENP-C (see Section 3), the interaction of CENP-C with the Mis12 complex is likely the only linkage between the inner and outer kinetochore. Consistent with this notion, a tight CENP-C interaction with the Mis12 complex has been observed in biochemical reconstitutions of the D. melanogaster outer kinetochore $[245,246]$. Thus, from the analysis in different models to date, it appears that the CENP-C-outer kinetochore linkage is more commonly employed, although in the vertebrate species analyzed to date the CENP-T linkage makes the more dominant contribution to Ndc80 complex recruitment. Interestingly, the CENP-T ortholog in S. pombe (Cnp20) unlike Cnn1 in S. cerevisiae, is essential for viability [166]. Additional work on S. pombe CENP-T is needed to address whether its essential function relates to outer kinetochore assembly. More broadly, asking precisely why two types of linkages have evolved to link the inner and outer kinetochore and asking whether there is a functional specialization of these linkages are important questions for future studies.

In summary, the plan of kinetochore assembly from the chromatin layer to the outer kinetochore has been now delineated in significant detail. Crucial features of this assembly plan include: (1) Recruitment of all kinetochore proteins ultimately depends on specific interactions with CENP-A. CENP-C, CENP-N, and CENP-T, which have been implicated as the proteins at the base of the kinetochore, require CENP-A for their localization; (2) Both CENP-C and CENP-N bind directly to the CENP-A nucleosome; (3) CENP-T does not bind directly to the CENP-A nucleosome, but appears to recognize a combination of the CENP-HIKM complex (which interacts directly with CENP-C and CENP-NL) and naked DNA, possibly in a linker region neighboring the CENP-A nucleosome; (4) CENP-C creates a direct linkage between CENP-A (and its associated CCAN subunits) and the KMN network, binding concomitantly to both, and acting in analogy to a 'blueprint' to order kinetochore assembly; (5) CENP-T plays an analogous bridging function, and its N-terminal region can even replace 
the N-terminal region of CENP-C involved in Mis12 binding in an engineered context. The latter observation suggests that CENP-C and CENP-T might be distantly related in evolution.

These principles, which summarize a vast body of literature, were recently implemented in the biochemical reconstitution of a 21-subunit kinetochore particle containing the CENP-A nucleosome, the CENP-CHIKMLN complex, and the KMN network [110]. The reconstituted complex was shown to be sufficient to associate the CENP-A nucleosome with microtubules in vitro, demonstrating that its components can create a linkage between DNA associated with CENP-A and microtubules. Lacking from the reconstitution were the CENP-TW (and CENP-SX) complex and the CENP-OPQRU complex. The latter binds directly and with high affinity to the CENP-CHIKMLN complex, whereas incorporation of the former might require, as suggested above, a more complex chromatin template than a single CENP-A nucleosome.

A reconstitution approach also has the potential to fully define the CEN DNA-based kinetochore in S. cerevisiae that is built on a single well-positioned CENP-A nucleosome and binds to a single microtubule. Work on isolated kinetochore particles purified from S. cerevisiae has begun to illustrate the overall structural organization of this unit kinetochore and its microtubule binding modes [290,291] (Figure 7). When imaged by negative stain EM, the kinetochore particles had a central core of $\sim 37 \mathrm{~nm}$ diameter, and were radially surrounded by 5 to 7 globular domains with $\sim 21 \mathrm{~nm}$ diameter. When bound to microtubules, the particles appeared to contain a 50-nm ring structure surrounding the microtubule (likely the Dam1 complex), linked through a fibrous network (likely the Ndc80 complex) to the globular region. Two sites of microtubule attachment were visible, one coinciding with the ring structure and one at the junction of the fibrous structure with the globular region [291]. Continued analysis of yeast kinetochore particles and of human kinetochore reconstitutions of the type described recently should yield detailed insight into the structure and microtubule interaction properties of a unit kinetochore module in the foreseeable future.

\subsection{Stoichiometry of Kinetochore Subunits}

Estimates of the stoichiometry of human kinetochore composition were recently obtained through distinct experimental efforts, including biochemical reconstitution combined with analytical ultracentrifugation, and measurements of fluorescence intensity ratios in cells $[110,288]$. Biochemical reconstitution suggests that there are two CCAN complexes per CENP-A nucleosome [110]. As explained above, both CENP-C and CENP-T interact directly with the Mis12 complex, but their binding is mutually exclusive, implying that each of the two CCAN subunits has the potential to recruit the Mis12 complex independently [239]. Thus, if two copies of CENP-C and CENP-T associate with a CENP-A nucleosome, and each of them recruits Mis12, four Mis12 complexes will associated with the CENP-A nucleosome. Because each Mis12 complex also carries tightly bound $\mathrm{Ndc} 80$ and Knl1 complexes, as predicted by biochemical reconstitution experiments, at least four of each should be present. Furthermore, each CENP-T can also directly recruit up to two additional Ndc80 complexes, depending on the degree of saturation of phosphorylation and binding $[113,239]$. These numbers, summarized in Figure 8, are in excellent agreement with those obtained by quantification of fluorescence intensity at kinetochores [288]. In S. cerevisiae, early fluorescence measurements suggested $\sim 8 \mathrm{KMN}$ per centromeric CENP-A ${ }^{\mathrm{Cse} 4}$ nucleosome (or, more precisely, 8-fold higher fluorescence intensity for KMN subunits relative to CENP-A ${ }^{\text {Cse4 }}$ in the cluster of 16 centromeres). As deletion of the CENP-T ortholog Cnn1 does not reduce kinetochore-localized Ndc80, which is in contrast to what is observed in human cells, how this stoichiometry is achieved remains at present unclear. 

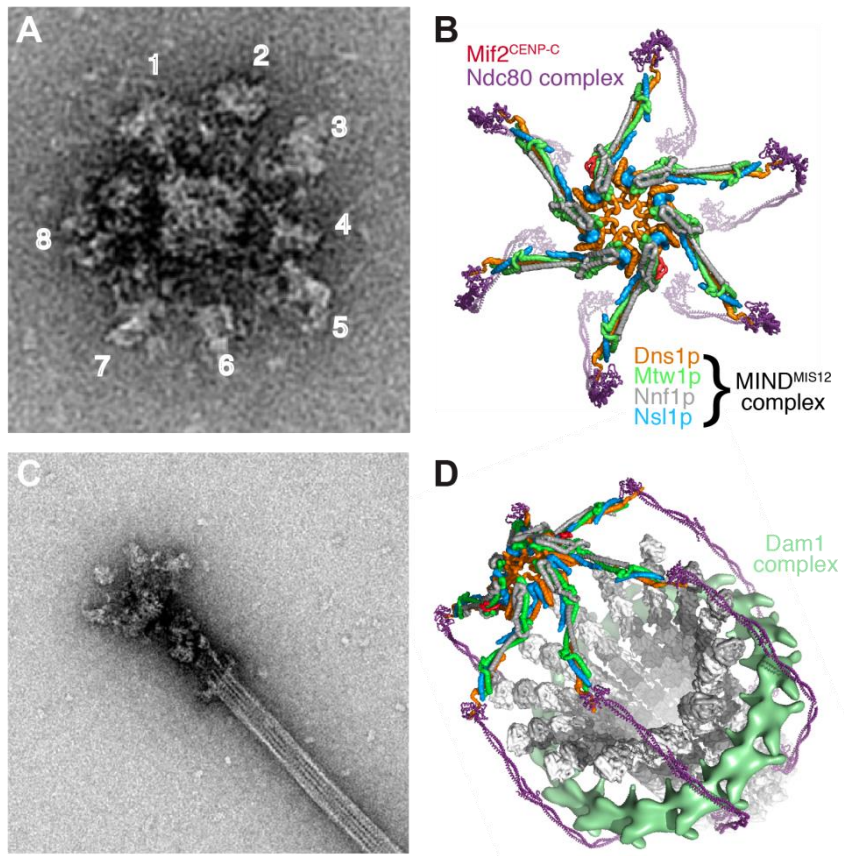

Figure 7. Images and structural model of budding yeast kinetochore particles. (A) Negative stain electron micrographs showing a kinetochore particle isolated from S. cerevisiae [291]. Images in this panel and in C courtesy of Sue Biggins and Tamir Gonen; (B) A rendered image with possible molecular interpretation of the negatively stained particles showing MIND ${ }^{\mathrm{MIS12}}$ :CENP-C complexes departing from a central "hub" and connecting with Ndc80 complexes. Image reproduced with permission from reference [240]; (C) Negative stain electron micrographs showing a S. cerevisiae kinetochore particle bound to the end of a taxol-stabilized microtubule [291]. Image courtesy of Sue Biggins and Tamir Gonen; (D) The structure in (B) is shown to surround the microtubule in end-on configuration. The Dam1 complex stabilizes the arrangement by surrounding the microtubule. Image reproduced with permission from reference [240].

\subsection{Temporal Framework of Kinetochore Assembly and Disassembly}

The majority of CCAN subunits display continued centromere localization (defined as co-localization with CENP-A foci) during the cell cycle and, in most cases, negligible turnover rates [292-295]. Nonetheless, studies on the reciprocal dependencies of CCAN subunits during the cell cycle indicate clear differences between interphase and mitosis. For instance, CENP-C localization to centromeres appears to depend on CENP-HIKM subunits during interphase but not in mitosis (for instance see references $[80,110,111,296]$ ). New kinetochore incorporation of CENP-TW, CENP-N, and CENP-U may occur during DNA replication [177,297-299]. The kinetochore levels of CENP-OPQRU subunits, on the other hand, appear to decrease as cells enter mitosis [294,300]. The molecular basis for cell cycle-dependent regulation of CCAN subunit loading and stability is largely unknown. Phosphorylation likely plays a role in these processes [301].

Mitotic maturation of kinetochores focuses mainly on the creation of the outer kinetochore. In vertebrate cells, the KMN subunits are not localized with CENP-A foci in G1, but begin to be recruited in S-phase and G2, with the Ndc80 complex being the last to be recruited, due to its exclusion from the nuclear compartment and to its dependence on CDK activity for kinetochore localization [239,242,279,281,292,302]. In D. melanogaster, KMN assembly may only occur later, in prophase, but follows a similar assembly order, with the Mis12 complex and Knl1 ${ }^{\mathrm{Spc} 105}$ assembly leading to $\mathrm{Ndc} 80$ complex recruitment after nuclear envelope breakdown [303]. As already clarified above, stabilization of the interaction of Mis12 with CENP-C might be an initiating trigger in KMN 
assembly on kinetochores. The components of the KMN network, on the other hand, disassemble from kinetochores at anaphase [292].

Probably the most dramatic physical transformation of regional kinetochores in metazoans is the formation of crescent-like shapes on their surface $[7,8,24-26]$. This phenomenon precedes end-on microtubule binding by the Ndc80 complex, and is believed to increase the likelihood of microtubule capture as well as to promote SAC signaling [8,27]. Proteins involved in this expansion had been previously localized to the kinetochore corona and include the microtubule motor CENP-E [26], the large $(\sim 400 \mathrm{kD})$ microtubule-binding protein CENP-F [8,304], and the dynein/dynactin motor complex along with its kinetochore targeting adaptors, the Rod-Zwilch-ZW10 (RZZ) complex [305]. RZZ's largest subunit, Rod, is structurally related to clathrin [306], pointing to its oligomerization as a possible driver of corona expansion.

As clarified in more detail in the chapter by Maiato and colleagues [255], the RZZ complex is required for kinetochore recruitment of the minus-end directed motor cytoplasmic Dynein. This function of RZZ requires an additional protein named Spindly, which additionally acts as an adaptor capable of stimulating Dynein motility [232,307-313]. Kinetochore localization of Spindly requires the RZZ complex and farnesylation on a Cys residue near the C-terminus of Spindly [314,315]. Interestingly, the motor protein CENP-E and the microtubule-binding component CENP-F that also localize to the corona region of the kinetochore are both farnesylated [316,317].

Upon conversion of kinetochore attachments from lateral to end-on, i.e., when $\mathrm{Ndc} 80$ gains the upper hand in the attachment mechanism, the shape of kinetochores converts from an extended crescent to a smaller, plate-like appearance [8,27]. This shape change is associated with the motor-dependent release of the Dynein:Dynactin:Spindly:RZZ complex from kinetochores towards spindle poles [318-325]. The central spindle assembly checkpoint component, the Mad1:Mad2 complex, is also removed from kinetochores through this mechanism, effectively terminating SAC signaling by the kinetochore [325-331].

This brief section highlights that kinetochore assembly is regulated in response to cell cycle cues and kinetochore composition changes in response to microtubule attachment. Defining precisely how regulation operates in these two contexts is an important challenge for the future.

\section{Organization of the Chromatin Foundation of the Kinetochore in Regional Centromeres}

The above sections have focused on discrete, high-affinity stoichiometric physical interactions of kinetochore subunits that build the kinetochore on its chromatin foundation. This type of approach is helping define the assembly unit of the human kinetochore, which we propose has a CENP-A and H3.3 dinucleosome as its foundation (Figure 8). The remarkable progress made on understanding high-affinity stoichiometric interactions masks a relative paucity of information on how the regional or holocentric centromeres of most metazoan species, where a small number of CENP-A nucleosomes are interspersed with a large excess of $\mathrm{H} 3$ nucleosomes, are organized to form a multi-microtubule binding kinetochore. While it is generally assumed that individual CENP-A nucleosomes will recruit machinery resembling the unit kinetochore module described above [332,333], how these modules are clustered and organized to build a 'surface' with a high density of kinetochore components on a CENP-A nucleosomal platform is not known. In S. pombe, $10-15$ CENP-A ${ }^{\text {Cnp1 }}$ nucleosomes in the $10 \mathrm{~kb}$ centromeric central core region drive the assembly of kinetochores capable of binding three microtubules [334,335]. At human centromeres, which bind 20 microtubules, current estimates indicate that 100 CENP-A nucleosomes are present but are dispersed in a large centromeric DNA region in which CENP-A is largely substoichiometric relative to H3 (roughly 1 to 25) [169]. Within such large repetitive centromere regions, CENP-A may be enriched in arrays forming discrete sub-domains [336-338]. How centromeric chromatin folds to expose the CENP-A domains for kinetochore assembly is currently unclear, and several models have been discussed [6]. Of note, studies in S. cerevisiae have suggested that the high density of cohesin flanking centromeres may aid extrusion of loops on the termini of which CENP-A ${ }^{\text {Cse4 }}$ nucleosomes are present. This line of thinking, stimulated 
by models of chromatin polymer properties, suggests that the 16 kinetochores of budding yeast may be organized in a manner that resembles multi-microtubule binding kinetochores of metazoans [339-341] (Figure 7). In the holocentric nematode Caenorhabditis elegans, CENP-A occupies non-repetitive regions of 10-12 kb dispersed across about half of the genome and is excluded from loci that are transcribed in the germline and early embryo [342]; for a different view that suggests the presence of focused spots of functional CENP-A in C. elegans, in addition to the pattern summarize above, see [343]). Notably, in this holocentric species, CENP-A removal, but not CENP-C removal, causes chromosome structure/condensation defects [344], suggesting that CENP-A chromatin, independently of its role in kinetochore assembly, has a propensity to coordinate structural organization of chromatin, potentially via its intrinsic properties or via effectors other than those required to build a kinetochore.

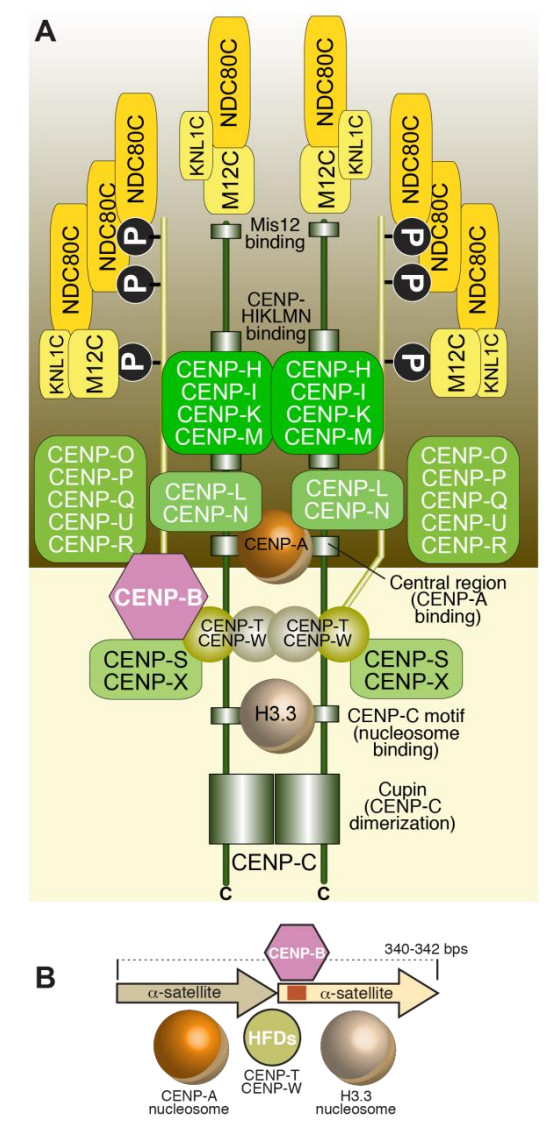

Figure 8. A model for the assembly unit of the human kinetochore. The kinetochore assembly unit is depicted as being organized on a CENP-A-H3.3 dinucleosome. (A) A primary determinant of the stoichiometry of kinetochore subunits is the valency of the CENP-A nucleosome, which confers the potential to interact with two CCAN complexes, as shown in work of in vitro reconstitution of kinetochore assembly [110]. Because CENP-C and CENP-T each carries a full KMN network, and CENP-T additionally carries two NDC80 complexes, there are four MIS12 and KNL1 complexes per CENP-A nucleosome, and up to 8 NDC80 complexes. CENP-C has the potential to interact with two nucleosomes (see Figure 3), with one of them (the one bound to the CENP-C central region) is a CENP-A nucleosome permanently marked by interactions with stably bound CCAN subunits. As clarified in Figure 9, we speculate that the identity of the second nucleosome, which binds to the CENP-C motif, varies during the cell cycle, alternating between CENP-A and H3.3. The C-terminal dimerization domain of CENP-C might "seal" this design. During mitosis, the second nucleosome is an H3.3 nucleosome; (B) This speculative design is compatible with the existence of the tandem $\alpha$-satellite structures already discussed in Figure 2. CENP-TW is proposed to bind in the inter-nucleosomal linker region, near the CENP-B box. 
As discussed in Section 5, the assembly unit of a kinetochore likely contains multiple Ndc80 complexes. Modulation by Aurora B phosphorylation of the binding affinity of each of these complexes for microtubules (see Section 4) likely gives rise to a considerable dynamic range of microtubule binding affinities. While kinetochores built on point centromeres bind a single microtubule, those built on regional centromeres bind multiple microtubules, but it is currently unclear whether a kinetochore module within regional kinetochores is associated with a single or multiple microtubules. In modeling studies, a random distribution of $\mathrm{Ndc} 80$ complexes on the kinetochore surface proves more versatile in comparison to the clustering into discrete regions binding a single microtubule $[229,233]$. Whether the scattering model is compatible with the kinetochore construction principles we have illustrated, however, remains to be clarified.

This section illustrates a major gap in our understanding of kinetochore structure in a majority of species-how the dispersed and rare CENP-A nucleosomes at repetitive centromeres are collected and organized to form a base for kinetochore assembly. The properties of this complex chromatin domain are also relatively poorly understood. This gap in turn leaves open the important question how microtubule-binding sites are organized to efficiently capture and couple dynamic microtubules and how multiple microtubule-binding sites are coordinated. Recent work is beginning to reveal the importance of transcriptional activity at centromeres that may contribute to centromere structural organization. Repeats at centromeres are transcribed and active RNA polymerase II is detected at centromeres [345-348]. In addition, complexes implicated in transcription, most notably the FACT complex that remodels chromatin during transcription, has been co-purified with CENP-A chromatin in multiple independent studies, has been implicated in CENP-A loading, and was recently reported to interact with CENP-T $[97,99,112,349]$. Numerous concepts are currently being explored on the role of transcriptional activity, including creation of paused transcription sites, generation of centromeric RNAs that somehow act in centromere assembly, and generation of a chromatin state that is conducive to CENP-A loading [350-352].

\section{The Propagation of Centromeric Chromatin}

A fundamental requirement for the epigenetic specification of centromeres is that the pool of CENP-A be maintained through cell division. In the absence of specific recognition of the underlying DNA sequence, this process is likely to be directed by the existing pool of CENP-A [72]. In vertebrates, incorporation of new CENP-A at centromeres occurs after mitotic exit, from mitotic telophase till early G1 phase $[135,153,177,299,353]$. The CENP-A pool is then distributed, without new incorporation, to the sister chromatids during DNA replication, with the resulting gaps being probably filled with histone H3.3 [354]. Thus, sister chromatids enter mitosis with half as much CENP-A as that present on the parental chromosome before replication. In the absence of sequence-specific interactions with DNA, a crucial unresolved question is if CENP-A positional information is retained during DNA replication, when the nucleosome structure of the centromere is likely to become temporarily perturbed, and if so, how. Once incorporated into chromatin, CENP-A is not further evicted, showing negligible dissociation kinetics [141,152,153,295,355].

Several factors involved in the deposition of new CENP-A have emerged [4,6] (Figure 9). The Mis18 complex, first identified based on a mutant in S. pombe, includes Mis18 (orthologous to human paralogs Mis18 $\alpha$ and Mis18 $\beta$ ) and Mis16 (orthologous to human proteins RbAp46/48, and acting as histone chaperones in several histone modification complexes) [339,356-359]. Mis18 forms oligomers in S. pombe and humans [360,361]. The Mis18 complex further interacts with M18BP1 (Mis18 binding protein 1, also known as Knl2) [356-358,362,363]. No Mis18BP1 has been identified in S. pombe, but two recently identified proteins, Mis19/Eic1 and Mis20/Eic2 may act as functional orthologs of M18BP1 in this organism [364,365]. 


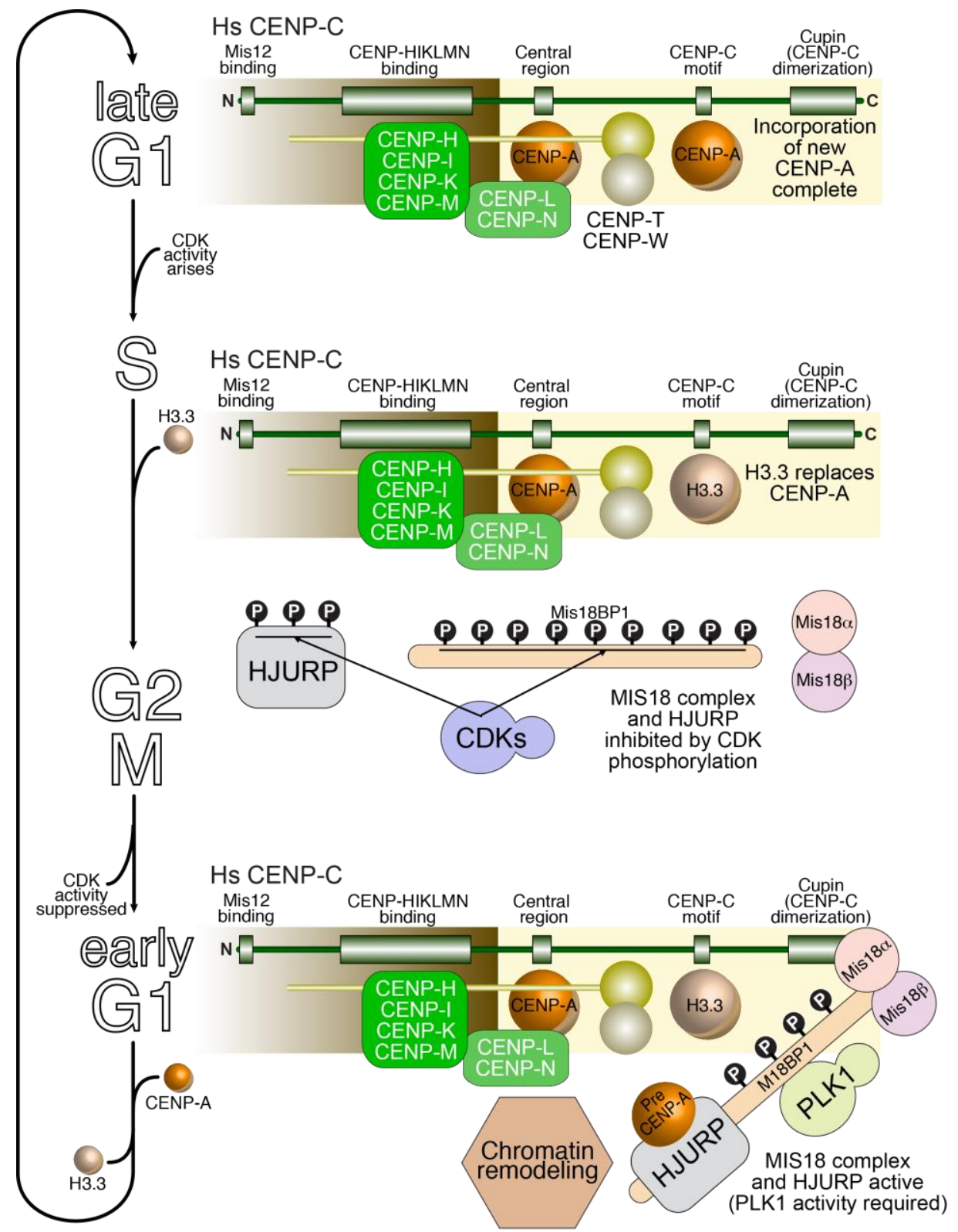

Figure 9. Cell cycle-regulated replenishment of CENP-A nucleosomes New. CENP-A incorporation takes place after mitotic exit, early in G1 phase (bottom). It is driven by an existing, active CENP-A nucleosome (e.g., because bound to CCAN subunits), and directed on a neighboring nucleosome. Here, we hypothesize that the neighboring nucleosome in humans is already bound to the CENP-C motif of CENP-C. An active MIS18 complex, including M18BP1, recruits HJURP, which binds to pre-nucleosomal CENP-A. The C-terminal region of CENP-C has been implicated in this reaction, which also requires PLK1 activity. A chromatin-remodeling factor and other chromatin-associated factors promote extraction of H3.3 and its replacement with CENP-A through an ATP-dependent reaction. The resulting configuration (top) persists until DNA replication (S-phase), when CENP-A "vacancies" caused by distribution of CENP-A to the sister chromatids during DNA replication, are filled with H3.3. This configuration then persists through the rest of the cell cycle until mitotic exit, because the CENP-A loading machinery is inhibited by CDK activity (middle).

The Mis18 complex, in conjunction with M18BP1, mediates a cell-cycle-regulated interaction with kinetochores that ultimately promotes the localization of a CENP-A selective histone chaperone known in vertebrates as HJURP (Holliday Junction-Recognizing Protein) [366-368]. Functional orthologs 
with limited sequence similarity to HJURP exist in S. cerevisiae, S. pombe, and D. melanogaster (named Scm3 and Cal1) [369-379]. HJURP, which may form functional dimers [380], contains an N-terminal Scm3-homology domain that binds pre-nucleosomal CENP-A [73,75,158,381-384]. Its central region, on the other hand, mediates binding to M18BP1 and is required for kinetochore recruitment $[73,385,386]$. The precise mechanism of kinetochore recruitment of the Mis18 complex and HJURP remains unclear, but interactions with CCAN subunits, including CENP-I ${ }^{\text {Mis6 }}$ and CENP-C, have been identified [75,158,374,378,385,387-391]. In S. cerevisiae, on the other hand, Scm3 is recruited through an interaction with the CBF3 complex [371].

CENP-A deposition is tightly coordinated with cell cycle progression in a manner distinct from canonical histone $\mathrm{H} 3$, which is deposited concomitantly with DNA replication in S-phase. In vertebrates, incorporation of new CENP-A is limited to telophase and early G1, when CDK activity is suppressed [392-395]. The increase in CDK activity that precedes the initiation of DNA replication may be sufficient for inhibition of CENP-A deposition, implicating pre-mitotic Cdk2 kinase activity in complex with Cyclin E and Cyclin A as potential negative regulators of this process. A major target of this regulation is M18BP1, which CDKs phosphorylate at multiple sites, preventing its interaction with Mis18 subunits and its kinetochore recruitment [392,395,396]. Inhibition of CENP-A deposition through phosphorylation of HJURP and CENP-A has also been described [393,394,396,397].

The activity of another kinase, Polo-like Kinase 1 (Plk1), on the other hand, is required for the incorporation of new CENP-A [395]. Suppression of CDK activity in the G2 phase of the cell cycle results in ectopic and Plk1-dependent incorporation of CENP-A, suggesting that Plk1 is required for CENP-A deposition but does not contribute to cell cycle phase coordination. Like CDKs, Plk1 also targets the Mis18:M18BP1 complex, but the precise interactions controlled by this kinase remain to be discovered.

The molecular mechanism of new CENP-A deposition remains unclear [5]. Factors implicated in CENP-A deposition, or in its stable maintenance at centromeres, include the chromatin remodeling FACT complex, the histone chaperone NPM1/nucleophosmin, the GTPase-activating protein MgcRacGAP, And-1, and Condensin II [99,112,349,368,398-405]. The RSF and MgcRacGAP, the latter identified as a binding partner of [363] P1/Knl2, have been implicated specifically in the maintenance of newly incorporated CENP-A [400]. Several DNA and histone post-translational modifications have been implicated in CENP-A loading, including DNA methylation by DNMT3B, possibly through interactions with the C-terminal region of CENP-C and with Mis18 $\alpha$ [406,407], acetylation [402,408,409], and histone H3K4 dimethylation [410,411].

As clarified above, during DNA replication the chromosome levels of CENP-A are reduced by $50 \%$. It has been proposed that the CENP-A 'vacancies' generated at this stage are filled by placeholder histone H3.3 [354]. New CENP-A deposition in telophase and early G1 may therefore require the eviction of the H3.3 previously used to fill the CENP-A vacancy, and its replacement with CENP-A. Existing kinetochores provide a recruitment platform for the CENP-A deposition machinery, limiting its function to existing centromeres. The amount of CENP-A on each chromosome appears to be constant through generations, implying that each CENP-A may only trigger a single cycle of CENP-A incorporation [412,413]. Like other histone replacement reactions [414], rapid replacement of H3 with CENP-A is likely to require a source of energy. The ATPase carrying out the replacement has not yet been identified with certainty. Two chromatin-remodeling enzymes, Chd1 and RSF, have been implicated in CENP-A deposition in human cells [99,112,401], while Chd1 appears to be dispensable for CENP-A deposition in D. melanogaster [415].

If the CENP-A deposition reaction implies the substitution of $\mathrm{H} 3.3$ with CENP-A, a crucial question is how the CENP-A deposition machinery targets a specific $\mathrm{H} 3.3$ nucleosome neighboring CENP-A. Likely, there are specific molecular features that designate it as the nucleosome to be replaced. We suggest that the C-terminal region of CENP-C is responsible for this labeling function (Figure 9). As explained in Section 3, the N-terminal region of CENP-C, comprising a succession of binding sites for Mis12, the CENP-CHIKMLN complex, and CENP-A, is required for kinetochore assembly $[110,165]$. 
However, CENP-C contains a second nucleosome-binding motif, the CENP-C motif, and we surmise that it mediates the association with a second nucleosome. Our speculative working model is that the structure recognized by the CENP-A deposition machinery is a CENP-A:H3 dinucleosome in which CENP-C acts as a bridge between the two nucleosomes. After eviction of $\mathrm{H} 3$ and deposition of CENP-A, the deposition reaction is complete and the deposition machinery dissociates.

This model predicts that the core kinetochore module in regional kinetochores is a dinucleosome structure. One of the nucleosomes has permanent identity as CENP-A, being bound to the N-terminal region of CENP-C where all CCAN subunits stably assemble. The second one, bound to the C-terminal region of CENP-C (implicated in recruitment of the CENP-A deposition machinery, as observed above), toggles between two identities (H3 and CENP-A) during the cell cycle (Figure 9). While this hypothesis requires considerable further scrutiny, it is consistent with studies showing that human CENP-A nucleosomes are enriched on units of $\sim 340$ bps consisting of two $\alpha$-satellite repeats separated by a CENP-B box, and on which CENP-B, CENP-C, and CENP-T also appear to co-exist with two CENP-A molecules in a single complex [77,78,416]. Dimeric repeat units are observed in other mammals [417]. In S. cerevisiae, where a specific DNA motif defines the centromere, only the organization of the "permanent" CENP-A nucleosome is preserved, while CBF3 functionally replaces the second nucleosome by providing direct DNA recognition and by recruiting the $\mathrm{Scm} 3$ chaperone. In this organism, deposition of new Cse4 occurs concomitantly with DNA replication $[355,418]$.

\section{Unconventional Kinetochores}

Our discussion above has focused on kinetochore assembly that occurs on CENP-A nucleosomal chromatin. The picture we present, in which CENP-A nucleosomal chromatin recruits CCAN components that recruit KMN complexes that in turn recruit other microtubule-interacting proteins and SAC machinery, is true in budding and fission yeast, D. melanogaster, C. elegans, and vertebrates. However, notable exceptions to this picture have been found and have the potential to reveal core principles on how kinetochores are built to couple to microtubules and ensure chromosome segregation. The most striking exception found to date is in kinetoplastids, where proteins that are homologous to the majority of the kinetochore proteins we discussed here (CENP-A, CCAN, KMN) have not been found. Based on tagging and proteomic analysis, 20 kinetochore proteins have been identified in the kinetoplastid Trypanosoma brucei [419] and their detailed characterization should reveal how this divergent kinetochore is built and operates. Based on weak homology to the Ndc80 and Nuf2 coiled-coils, a very recent study identified a new kinetochore-localized protein in T. brucei that is important for chromosome segregation [420]. Although this protein lacks the calponin homology $(\mathrm{CH})$ domains of Ndc80 and Nuf2 that mediate microtubule binding, the sequence homology in the coiled coil suggests divergence from an ancestral Ndc80/Nuf2-like protein. Kinetoplastids are classified as belonging to a diverse group of eukaryotes (known as the Excavata) that are distinct from the group that contains the commonly studied model organisms (known as the Opisthokonta). Giardia intestinalis, a diplomonad that is also classified as belonging to the Excavata group, does have a CENP-A-like histone and KMN proteins. Thus, kinetoplastids exhibit extreme divergence of ancestral components together with emergence of new kinetochore machinery, the reasons for which are currently mysterious. A second exception to the canonical kinetochore assembly pathway is observed in holocentric insect species, which have independently arisen multiple times. In at least four independent lineages of insects where holocentricity evolved, CENP-A and CENP-C appear to have been lost but KMN components are still present [62]. Thus, these holocentric insect lineages appear to build their kinetochores on a different foundation than CENP-A. This finding echoes earlier work in C. elegans, where the mitotic kinetochore requires CENP-A for assembly and follows the canonical pathway but the meiotic kinetochore in oocytes is built independently of CENP-A and CENP-C [421]. Defining how the holocentric insect kinetochore is built independently of CENP-A and assessing whether an epigenetic inheritance mechanism, similar to what is observed with a CENP-A based kinetochore foundation, is also operating in these species will be very revealing. 


\section{Conclusions}

In this review, we have focused on the structural organization of the kinetochore. It is with this largely evolutionarily conserved scaffold that the kinetochore performs its complex functions, including error correction, spindle assembly checkpoint control, and chromosome alignment and segregation. While a detailed mechanistic understanding of kinetochore dynamics is still lacking, our grasp of kinetochore architecture inspires molecular hypotheses on the molecular changes to kinetochore architecture that distinguish microtubule-bound and -unbound states and their signaling properties.

Acknowledgments: Andrea Musacchio acknowledges funding by the European Research Council (ERC) AdG RECEPIANCE (No. 669686) and the DFG's Collaborative Research Centre (CRC) 1093. Arshad Desai acknowledges funding from the NIH (GM074215) and the Ludwig Institute for Cancer Research. Yoana Dimitrova, Stephen C. Harrison, Alexey Khodjakov, Sue Biggins, Tamir Gonen, Pim Huis in 't Veld, and J. Richard McIntosh contributed original figure panels.

Author Contributions: Andrea Musacchio and Arshad Desai discussed the content of the review and wrote it.

Conflicts of Interest: The authors declare no conflict of interest.

\section{References}

1. Cheeseman, I.M. The kinetochore. Cold Spring Harb. Perspect. Biol. 2014, 6, a015826. [CrossRef] [PubMed]

2. Nagpal, H.; Fukagawa, T. Kinetochore assembly and function through the cell cycle. Chromosoma 2016, 125, 645-659. [CrossRef] [PubMed]

3. Pesenti, M.E.; Weir, J.R.; Musacchio, A. Progress in the structural and functional characterization of kinetochores. Curr. Opin. Struct. Biol. 2016, 37, 152-163. [CrossRef] [PubMed]

4. McKinley, K.L.; Cheeseman, I.M. The molecular basis for centromere identity and function. Nat. Rev. Mol. Cell Biol. 2016, 17, 16-29. [CrossRef] [PubMed]

5. Muller, S.; Almouzni, G. A network of players in H3 histone variant deposition and maintenance at centromeres. Biochim. Biophys. Acta 2014, 1839, 241-250. [CrossRef] [PubMed]

6. Fukagawa, T.; Earnshaw, W.C. The centromere: Chromatin foundation for the kinetochore machinery. Dev. Cell 2014, 30, 496-508. [CrossRef] [PubMed]

7. Rieder, C.L. The formation, structure, and composition of the mammalian kinetochore and kinetochore fiber. Int. Rev. Cytol. 1982, 79, 1-58. [PubMed]

8. Magidson, V.; Paul, R.; Yang, N.; Ault, J.G.; O'Connell, C.B.; Tikhonenko, I.; McEwen, B.F.; Mogilner, A.; Khodjakov, A. Adaptive changes in the kinetochore architecture facilitate proper spindle assembly. Nat. Cell Biol. 2015, 17, 1134-1144. [CrossRef] [PubMed]

9. Foley, E.A.; Kapoor, T.M. Microtubule attachment and spindle assembly checkpoint signalling at the kinetochore. Nat. Rev. Mol. Cell Biol. 2013, 14, 25-37. [CrossRef] [PubMed]

10. Nicklas, R.B.; Koch, C.A. Chromosome micromanipulation. 3. Spindle fiber tension and the reorientation of mal-oriented chromosomes. J. Cell Biol. 1969, 43, 40-50. [CrossRef] [PubMed]

11. Uchida, K.S.; Takagaki, K.; Kumada, K.; Hirayama, Y.; Noda, T.; Hirota, T. Kinetochore stretching inactivates the spindle assembly checkpoint. J. Cell Biol. 2009, 184, 383-390. [CrossRef] [PubMed]

12. Maresca, T.J.; Salmon, E.D. Intrakinetochore stretch is associated with changes in kinetochore phosphorylation and spindle assembly checkpoint activity. J. Cell Biol. 2009, 184, 373-381. [CrossRef] [PubMed]

13. Maresca, T.J.; Salmon, E.D. Welcome to a new kind of tension: Translating kinetochore mechanics into a wait-anaphase signal. J. Cell Sci. 2010, 123, 825-835. [CrossRef] [PubMed]

14. Lampson, M.A.; Grishchuk, E.L. Mechanisms to Avoid and Correct Erroneous Kinetochore-Microtubule Attachments. Biology (Basel) 2017, 6. [CrossRef]

15. Musacchio, A. The Molecular Biology of Spindle Assembly Checkpoint Signaling Dynamics. Curr. Biol. 2015, 25, R1002-R1018. [CrossRef] [PubMed]

16. London, N.; Biggins, S. Signalling dynamics in the spindle checkpoint response. Nat. Rev. Mol. Cell Biol. 2014, 15, 736-747. [CrossRef] [PubMed]

17. Joglekar, A.P. A Cell Biological Perspective on Past, Present and Future Investigations of the Spindle Assembly Checkpoint. Biology (Basel) 2016, 5, E44. [CrossRef] [PubMed] 
18. Brinkley, B.R.; Stubblefield, E. The fine structure of the kinetochore of a mammalian cell in vitro. Chromosoma 1966, 19, 28-43. [CrossRef] [PubMed]

19. Rieder, C.L.; Alexander, S.P. Kinetochores are transported poleward along a single astral microtubule during chromosome attachment to the spindle in newt lung cells. J. Cell Biol. 1990, 110, 81-95. [CrossRef] [PubMed]

20. McEwen, B.F.; Arena, J.T.; Frank, J.; Rieder, C.L. Structure of the colcemid-treated PtK1 kinetochore outer plate as determined by high voltage electron microscopic tomography. J. Cell Biol. 1993, 120, 301-312. [CrossRef] [PubMed]

21. Jokelainen, P.T. The ultrastructure and spatial organization of the metaphase kinetochore in mitotic rat cells. J. Ultrastruct. Res. 1967, 19, 19-44. [CrossRef]

22. Yao, X.; Anderson, K.L.; Cleveland, D.W. The microtubule-dependent motor centromere-associated protein E (CENP-E) is an integral component of kinetochore corona fibers that link centromeres to spindle microtubules. J. Cell Biol. 1997, 139, 435-447. [CrossRef] [PubMed]

23. Cooke, C.A.; Schaar, B.; Yen, T.J.; Earnshaw, W.C. Localization of CENP-E in the fibrous corona and outer plate of mammalian kinetochores from prometaphase through anaphase. Chromosoma 1997, 106, 446-455. [CrossRef] [PubMed]

24. Hoffman, D.B.; Pearson, C.G.; Yen, T.J.; Howell, B.J.; Salmon, E.D. Microtubule-dependent changes in assembly of microtubule motor proteins and mitotic spindle checkpoint proteins at PtK1 kinetochores. Mol. Biol. Cell 2001, 12, 1995-2009. [CrossRef] [PubMed]

25. Wynne, D.J.; Funabiki, H. Kinetochore function is controlled by a phospho-dependent coexpansion of inner and outer components. J. Cell Biol. 2015, 210, 899-916. [CrossRef] [PubMed]

26. Thrower, D.A.; Jordan, M.A.; Wilson, L. Modulation of CENP-E organization at kinetochores by spindle microtubule attachment. Cell Motil. Cytoskelet. 1996, 35, 121-133. [CrossRef]

27. Magidson, V.; He, J.; Ault, J.G.; O'Connell, C.B.; Yang, N.; Tikhonenko, I.; McEwen, B.F.; Sui, H.; Khodjakov, A. Unattached kinetochores rather than intrakinetochore tension arrest mitosis in taxol-treated cells. J. Cell Biol. 2016, 212, 307-319. [CrossRef] [PubMed]

28. Dong, Y.; Vanden Beldt, K.J.; Meng, X.; Khodjakov, A.; McEwen, B.F. The outer plate in vertebrate kinetochores is a flexible network with multiple microtubule interactions. Nat. Cell Biol. 2007, 9, 516-522. [CrossRef] [PubMed]

29. McIntosh, J.R.; Grishchuk, E.L.; Morphew, M.K.; Efremov, A.K.; Zhudenkov, K.; Volkov, V.A.; Cheeseman, I.M.; Desai, A.; Mastronarde, D.N.; Ataullakhanov, F.I. Fibrils connect microtubule tips with kinetochores: A mechanism to couple tubulin dynamics to chromosome motion. Cell 2008, 135, 322-333. [CrossRef] [PubMed]

30. Asbury, C.L. Anaphase A: Melting microtubules give mitosis its meaning. Biology (Basel) Submitted. 2017.

31. Clarke, L.; Carbon, J. Genomic substitutions of centromeres in Saccharomyces cerevisiae. Nature 1983, 305, 23-28. [CrossRef] [PubMed]

32. Clarke, L.; Carbon, J. Isolation of a yeast centromere and construction of functional small circular chromosomes. Nature 1980, 287, 504-509. [CrossRef] [PubMed]

33. Fitzgerald-Hayes, M.; Clarke, L.; Carbon, J. Nucleotide sequence comparisons and functional analysis of yeast centromere DNAs. Cell 1982, 29, 235-244. [CrossRef]

34. Lechner, J.; Carbon, J. A $240 \mathrm{kd}$ multisubunit protein complex, CBF3, is a major component of the budding yeast centromere. Cell 1991, 64, 717-725. [CrossRef]

35. Hieter, P.; Pridmore, D.; Hegemann, J.H.; Thomas, M.; Davis, R.W.; Philippsen, P. Functional selection and analysis of yeast centromeric DNA. Cell 1985, 42, 913-921. [CrossRef]

36. Pluta, A.F.; Mackay, A.M.; Ainsztein, A.M.; Goldberg, I.G.; Earnshaw, W.C. The centromere: Hub of chromosomal activities. Science 1995, 270, 1591-1594. [CrossRef] [PubMed]

37. Catania, S.; Allshire, R.C. Anarchic centromeres: Deciphering order from apparent chaos. Curr. Opin. Cell Biol. 2014, 26, 41-50. [CrossRef] [PubMed]

38. Aldrup-Macdonald, M.E.; Sullivan, B.A. The past, present, and future of human centromere genomics. Genes (Basel) 2014, 5, 33-50. [CrossRef] [PubMed]

39. Steiner, N.C.; Clarke, L. A novel epigenetic effect can alter centromere function in fission yeast. Cell 1994, 79, 865-874. [CrossRef]

40. Earnshaw, W.C.; Ratrie, H., 3rd; Stetten, G. Visualization of centromere proteins CENP-B and CENP-C on a stable dicentric chromosome in cytological spreads. Chromosoma 1989, 98, 1-12. [CrossRef] [PubMed] 
41. Sullivan, B.A.; Schwartz, S. Identification of centromeric antigens in dicentric Robertsonian translocations: CENP-C and CENP-E are necessary components of functional centromeres. Hum. Mol. Genet. 1995, 4, 2189-2197. [CrossRef] [PubMed]

42. Voullaire, L.E.; Slater, H.R.; Petrovic, V.; Choo, K.H. A functional marker centromere with no detectable alpha-satellite, satellite III, or CENP-B protein: Activation of a latent centromere? Am. J. Hum. Genet. 1993, 52, 1153-1163. [PubMed]

43. Du Sart, D.; Cancilla, M.R.; Earle, E.; Mao, J.I.; Saffery, R.; Tainton, K.M.; Kalitsis, P.; Martyn, J.; Barry, A.E.; Choo, K.H. A functional neo-centromere formed through activation of a latent human centromere and consisting of non-alpha-satellite DNA. Nat. Genet. 1997, 16, 144-153. [CrossRef] [PubMed]

44. Amor, D.J.; Bentley, K.; Ryan, J.; Perry, J.; Wong, L.; Slater, H.; Choo, K.H. Human centromere repositioning "in progress". Proc. Natl. Acad. Sci. USA 2004, 101, 6542-6547. [CrossRef] [PubMed]

45. Murphy, T.D.; Karpen, G.H. Localization of centromere function in a Drosophila minichromosome. Cell 1995, 82, 599-609. [CrossRef]

46. Shang, W.H.; Hori, T.; Toyoda, A.; Kato, J.; Popendorf, K.; Sakakibara, Y.; Fujiyama, A.; Fukagawa, T. Chickens possess centromeres with both extended tandem repeats and short non-tandem-repetitive sequences. Genome Res. 2010, 20, 1219-1228. [CrossRef] [PubMed]

47. Locke, D.P.; Hillier, L.W.; Warren, W.C.; Worley, K.C.; Nazareth, L.V.; Muzny, D.M.; Yang, S.P.; Wang, Z.; Chinwalla, A.T.; Minx, P.; et al. Comparative and demographic analysis of orang-utan genomes. Nature 2011, 469, 529-533. [CrossRef] [PubMed]

48. Piras, F.M.; Nergadze, S.G.; Magnani, E.; Bertoni, L.; Attolini, C.; Khoriauli, L.; Raimondi, E.; Giulotto, E. Uncoupling of satellite DNA and centromeric function in the genus equus. PLoS Genet. 2010, 6, e1000845. [CrossRef] [PubMed]

49. Wade, C.M.; Giulotto, E.; Sigurdsson, S.; Zoli, M.; Gnerre, S.; Imsland, F.; Lear, T.L.; Adelson, D.L.; Bailey, E.; Bellone, R.R.; et al. Genome sequence, comparative analysis, and population genetics of the domestic horse. Science 2009, 326, 865-867. [CrossRef] [PubMed]

50. Sanyal, K.; Baum, M.; Carbon, J. Centromeric DNA sequences in the pathogenic yeast Candida albicans are all different and unique. Proc. Natl. Acad. Sci. USA 2004, 101, 11374-11379. [CrossRef] [PubMed]

51. Montefalcone, G.; Tempesta, S.; Rocchi, M.; Archidiacono, N. Centromere repositioning. Genome Res. 1999, 9, 1184-1188. [CrossRef] [PubMed]

52. Rocchi, M.; Archidiacono, N.; Schempp, W.; Capozzi, O.; Stanyon, R. Centromere repositioning in mammals. Heredity (Edinb) 2012, 108, 59-67. [CrossRef] [PubMed]

53. Ventura, M.; Antonacci, F.; Cardone, M.F.; Stanyon, R.; D’Addabbo, P.; Cellamare, A.; Sprague, L.J.; Eichler, E.E.; Archidiacono, N.; Rocchi, M. Evolutionary formation of new centromeres in macaque. Science 2007, 316, 243-246. [CrossRef] [PubMed]

54. Wiens, G.R.; Sorger, P.K. Centromeric chromatin and epigenetic effects in kinetochore assembly. Cell 1998, 93, 313-316. [CrossRef]

55. Karpen, G.H.; Allshire, R.C. The case for epigenetic effects on centromere identity and function. Trends Genet. 1997, 13, 489-496. [CrossRef]

56. Murphy, T.D.; Karpen, G.H. Centromeres take flight: Alpha satellite and the quest for the human centromere. Cell 1998, 93, 317-320. [CrossRef]

57. Earnshaw, W.C.; Rothfield, N. Identification of a family of human centromere proteins using autoimmune sera from patients with scleroderma. Chromosoma 1985, 91, 313-321. [CrossRef] [PubMed]

58. Earnshaw, W.C. Discovering centromere proteins: From cold white hands to the A, B, C of CENPs. Nat. Rev. Mol. Cell Biol. 2015, 16, 443-449. [CrossRef] [PubMed]

59. Palmer, D.K.; O’Day, K.; Wener, M.H.; Andrews, B.S.; Margolis, R.L. A 17-kD centromere protein (CENP-A) copurifies with nucleosome core particles and with histones. J. Cell Biol. 1987, 104, 805-815. [CrossRef] [PubMed]

60. Palmer, D.K.; O’Day, K.; Trong, H.L.; Charbonneau, H.; Margolis, R.L. Purification of the centromere-specific protein CENP-A and demonstration that it is a distinctive histone. Proc. Natl. Acad. Sci. USA 1991, 88, 3734-3738. [CrossRef] [PubMed]

61. Sullivan, K.F.; Hechenberger, M.; Masri, K. Human CENP-A contains a histone H3 related histone fold domain that is required for targeting to the centromere. J. Cell Biol. 1994, 127, 581-592. [CrossRef] [PubMed] 
62. Drinnenberg, I.A.; deYoung, D.; Henikoff, S.; Malik, H.S. Recurrent loss of CenH3 is associated with independent transitions to holocentricity in insects. eLife 2014, 3. [CrossRef] [PubMed]

63. Warburton, P.E.; Cooke, C.A.; Bourassa, S.; Vafa, O.; Sullivan, B.A.; Stetten, G.; Gimelli, G.; Warburton, D.; Tyler-Smith, C.; Sullivan, K.F.; et al. Immunolocalization of cenp-a suggests a distinct nucleosome structure at the inner kinetochore plate of active centromeres. Curr. Biol. 1997, 7, 901-904. [CrossRef]

64. Stoler, S.; Keith, K.C.; Curnick, K.E.; Fitzgerald-Hayes, M. A mutation in CSE4, an essential gene encoding a novel chromatin-associated protein in yeast, causes chromosome nondisjunction and cell cycle arrest at mitosis. Genes Dev. 1995, 9, 573-586. [CrossRef] [PubMed]

65. Oegema, K.; Desai, A.; Rybina, S.; Kirkham, M.; Hyman, A.A. Functional analysis of kinetochore assembly in Caenorhabditis elegans. J. Cell Biol. 2001, 153, 1209-1226. [CrossRef] [PubMed]

66. Moore, L.L.; Roth, M.B. HCP-4, a CENP-C-like protein in Caenorhabditis elegans, is required for resolution of sister centromeres. J. Cell Biol. 2001, 153, 1199-1208. [CrossRef] [PubMed]

67. Howman, E.V.; Fowler, K.J.; Newson, A.J.; Redward, S.; MacDonald, A.C.; Kalitsis, P.; Choo, K.H. Early disruption of centromeric chromatin organization in centromere protein a (cenpa) null mice. Proc. Natl. Acad. Sci. USA 2000, 97, 1148-1153. [CrossRef] [PubMed]

68. Liu, S.T.; Rattner, J.B.; Jablonski, S.A.; Yen, T.J. Mapping the assembly pathways that specify formation of the trilaminar kinetochore plates in human cells. J. Cell Biol. 2006, 175, 41-53. [CrossRef] [PubMed]

69. Fachinetti, D.; Folco, H.D.; Nechemia-Arbely, Y.; Valente, L.P.; Nguyen, K.; Wong, A.J.; Zhu, Q.; Holland, A.J.; Desai, A.; Jansen, L.E.; et al. A two-step mechanism for epigenetic specification of centromere identity and function. Nat. Cell Biol. 2013, 15, 1056-1066. [CrossRef] [PubMed]

70. Logsdon, G.A.; Barrey, E.J.; Bassett, E.A.; DeNizio, J.E.; Guo, L.Y.; Panchenko, T.; Dawicki-McKenna, J.M.; Heun, P.; Black, B.E. Both tails and the centromere targeting domain of cenp-a are required for centromere establishment. J. Cell Biol. 2015, 208, 521-531. [CrossRef] [PubMed]

71. Heun, P.; Erhardt, S.; Blower, M.D.; Weiss, S.; Skora, A.D.; Karpen, G.H. Mislocalization of the Drosophila centromere-specific histone CID promotes formation of functional ectopic kinetochores. Dev. Cell 2006, 10, 303-315. [CrossRef] [PubMed]

72. Mendiburo, M.J.; Padeken, J.; Fulop, S.; Schepers, A.; Heun, P. Drosophila CENH3 is sufficient for centromere formation. Science 2011, 334, 686-690. [CrossRef] [PubMed]

73. Barnhart, M.C.; Kuich, P.H.; Stellfox, M.E.; Ward, J.A.; Bassett, E.A.; Black, B.E.; Foltz, D.R. Hjurp is a cenp-a chromatin assembly factor sufficient to form a functional de novo kinetochore. J. Cell Biol. 2011, 194, 229-243. [CrossRef] [PubMed]

74. Van Hooser, A.A.; Ouspenski, I.I.; Gregson, H.C.; Starr, D.A.; Yen, T.J.; Goldberg, M.L.; Yokomori, K.; Earnshaw, W.C.; Sullivan, K.F.; Brinkley, B.R. Specification of kinetochore-forming chromatin by the histone h3 variant cenp-a. J. Cell Sci. 2001, 114, 3529-3542. [PubMed]

75. Hori, T.; Shang, W.H.; Takeuchi, K.; Fukagawa, T. The CCAN recruits CENP-A to the centromere and forms the structural core for kinetochore assembly. J. Cell Biol. 2013, 200, 45-60. [CrossRef] [PubMed]

76. Guse, A.; Carroll, C.W.; Moree, B.; Fuller, C.J.; Straight, A.F. In vitro centromere and kinetochore assembly on defined chromatin templates. Nature 2011, 477, 354-358. [CrossRef] [PubMed]

77. Henikoff, J.G.; Thakur, J.; Kasinathan, S.; Henikoff, S. A unique chromatin complex occupies young alpha-satellite arrays of human centromeres. Sci. Adv. 2015, 1, e1400234. [CrossRef] [PubMed]

78. Thakur, J.; Henikoff, S. CENPT bridges adjacent CENPA nucleosomes on young human alpha-satellite dimers. Genome Res. 2016, 26, 1178-1187. [CrossRef] [PubMed]

79. Kato, H.; Jiang, J.; Zhou, B.R.; Rozendaal, M.; Feng, H.; Ghirlando, R.; Xiao, T.S.; Straight, A.F.; Bai, Y. A conserved mechanism for centromeric nucleosome recognition by centromere protein cenp-c. Science 2013, 340, 1110-1113. [CrossRef] [PubMed]

80. Klare, K.; Weir, J.R.; Basilico, F.; Zimniak, T.; Massimiliano, L.; Ludwigs, N.; Herzog, F.; Musacchio, A. Cenp-c is a blueprint for constitutive centromere-associated network assembly within human kinetochores. J. Cell Biol. 2015, 210, 11-22. [CrossRef] [PubMed]

81. Malik, H.S.; Henikoff, S. Conflict begets complexity: The evolution of centromeres. Curr. Opin. Genet. Dev. 2002, 12, 711-718. [CrossRef]

82. Talbert, P.B.; Bryson, T.D.; Henikoff, S. Adaptive evolution of centromere proteins in plants and animals. J. Biol. 2004, 3, 18. [CrossRef] [PubMed] 
83. Schueler, M.G.; Swanson, W.; Thomas, P.J.; Program, N.C.S.; Green, E.D. Adaptive evolution of foundation kinetochore proteins in primates. Mol. Biol. Evol. 2010, 27, 1585-1597. [CrossRef] [PubMed]

84. Chmatal, L.; Gabriel, S.I.; Mitsainas, G.P.; Martinez-Vargas, J.; Ventura, J.; Searle, J.B.; Schultz, R.M.; Lampson, M.A. Centromere strength provides the cell biological basis for meiotic drive and karyotype evolution in mice. Curr. Biol. 2014, 24, 2295-2300. [CrossRef] [PubMed]

85. Bassett, E.A.; Wood, S.; Salimian, K.J.; Ajith, S.; Foltz, D.R.; Black, B.E. Epigenetic centromere specification directs aurora B accumulation but is insufficient to efficiently correct mitotic errors. J. Cell Biol. 2010, 190, 177-185. [CrossRef] [PubMed]

86. Nonaka, N.; Kitajima, T.; Yokobayashi, S.; Xiao, G.; Yamamoto, M.; Grewal, S.I.; Watanabe, Y. Recruitment of cohesin to heterochromatic regions by swi6/hp1 in fission yeast. Nat. Cell Biol. 2002, 4, 89-93. [CrossRef] [PubMed]

87. Bernard, P.; Maure, J.F.; Partridge, J.F.; Genier, S.; Javerzat, J.P.; Allshire, R.C. Requirement of heterochromatin for cohesion at centromeres. Science 2001, 294, 2539-2542. [CrossRef] [PubMed]

88. Westermann, S.; Schleiffer, A. Family matters: Structural and functional conservation of centromere-associated proteins from yeast to humans. Trends Cell Biol. 2013, 23, 260-269. [CrossRef] [PubMed]

89. Meraldi, P.; McAinsh, A.D.; Rheinbay, E.; Sorger, P.K. Phylogenetic and structural analysis of centromeric DNA and kinetochore proteins. Genome Biol. 2006, 7, R23. [CrossRef] [PubMed]

90. Moroi, Y.; Peebles, C.; Fritzler, M.J.; Steigerwald, J.; Tan, E.M. Autoantibody to centromere (kinetochore) in scleroderma sera. Proc. Natl. Acad. Sci. USA 1980, 77, 1627-1631. [CrossRef] [PubMed]

91. Earnshaw, W.C.; Sullivan, K.F.; Machlin, P.S.; Cooke, C.A.; Kaiser, D.A.; Pollard, T.D.; Rothfield, N.F.; Cleveland, D.W. Molecular cloning of cdna for cenp-b, the major human centromere autoantigen. J. Cell Biol. 1987, 104, 817-829. [CrossRef] [PubMed]

92. Saitoh, H.; Tomkiel, J.; Cooke, C.A.; Ratrie, H., 3rd; Maurer, M.; Rothfield, N.F.; Earnshaw, W.C. Cenp-c, an autoantigen in scleroderma, is a component of the human inner kinetochore plate. Cell 1992, 70, 115-125. [CrossRef]

93. Nishihashi, A.; Haraguchi, T.; Hiraoka, Y.; Ikemura, T.; Regnier, V.; Dodson, H.; Earnshaw, W.C.; Fukagawa, T. Cenp-i is essential for centromere function in vertebrate cells. Dev. Cell 2002, 2, 463-476. [CrossRef]

94. Sugata, N.; Munekata, E.; Todokoro, K. Characterization of a novel kinetochore protein, cenp-h. J. Biol. Chem. 1999, 274, 27343-27346. [CrossRef] [PubMed]

95. Saitoh, S.; Takahashi, K.; Yanagida, M. Mis6, a fission yeast inner centromere protein, acts during g1/s and forms specialized chromatin required for equal segregation. Cell 1997, 90, 131-143. [CrossRef]

96. Okada, M.; Cheeseman, I.M.; Hori, T.; Okawa, K.; McLeod, I.X.; Yates, J.R., 3rd; Desai, A.; Fukagawa, T. The cenp-h-i complex is required for the efficient incorporation of newly synthesized cenp-a into centromeres. Nat. Cell Biol. 2006, 8, 446-457. [CrossRef] [PubMed]

97. Foltz, D.R.; Jansen, L.E.; Black, B.E.; Bailey, A.O.; Yates, J.R., 3rd; Cleveland, D.W. The human CENP-A centromeric nucleosome-associated complex. Nat. Cell Biol. 2006, 8, 458-469. [CrossRef] [PubMed]

98. Obuse, C.; Yang, H.; Nozaki, N.; Goto, S.; Okazaki, T.; Yoda, K. Proteomics analysis of the centromere complex from HeLa interphase cells: UV-damaged DNA binding protein 1 (DDB-1) is a component of the CEN-complex, while BMI-1 is transiently co-localized with the centromeric region in interphase. Genes Cells 2004, 9, 105-120. [CrossRef]

99. Izuta, H.; Ikeno, M.; Suzuki, N.; Tomonaga, T.; Nozaki, N.; Obuse, C.; Kisu, Y.; Goshima, N.; Nomura, F.; Nomura, N.; et al. Comprehensive analysis of the icen (interphase centromere complex) components enriched in the cenp-a chromatin of human cells. Genes Cells 2006, 11, 673-684. [CrossRef] [PubMed]

100. Hori, T.; Amano, M.; Suzuki, A.; Backer, C.B.; Welburn, J.P.; Dong, Y.; McEwen, B.F.; Shang, W.H.; Suzuki, E.; Okawa, K.; et al. CCAN makes multiple contacts with centromeric DNA to provide distinct pathways to the outer kinetochore. Cell 2008, 135, 1039-1052. [CrossRef] [PubMed]

101. Amano, M.; Suzuki, A.; Hori, T.; Backer, C.; Okawa, K.; Cheeseman, I.M.; Fukagawa, T. The CENP-S complex is essential for the stable assembly of outer kinetochore structure. J. Cell Biol. 2009, 186, 173-182. [CrossRef] [PubMed]

102. Cheeseman, I.M.; Desai, A. Molecular architecture of the kinetochore-microtubule interface. Nat. Rev. Mol. Cell Biol. 2008, 9, 33-46. [CrossRef] [PubMed]

103. Joglekar, A.P.; Bloom, K.; Salmon, E.D. In vivo protein architecture of the eukaryotic kinetochore with nanometer scale accuracy. Curr. Biol. 2009, 19, 694-699. [CrossRef] [PubMed] 
104. Wan, X.; O'Quinn, R.P.; Pierce, H.L.; Joglekar, A.P.; Gall, W.E.; DeLuca, J.G.; Carroll, C.W.; Liu, S.T.; Yen, T.J.; McEwen, B.F.; et al. Protein architecture of the human kinetochore microtubule attachment site. Cell 2009, 137, 672-684. [CrossRef] [PubMed]

105. Suzuki, A.; Badger, B.L.; Wan, X.; DeLuca, J.G.; Salmon, E.D. The architecture of ccan proteins creates a structural integrity to resist spindle forces and achieve proper intrakinetochore stretch. Dev. Cell 2014, 30, 717-730. [CrossRef] [PubMed]

106. Joglekar, A.P.; Bouck, D.C.; Molk, J.N.; Bloom, K.S.; Salmon, E.D. Molecular architecture of a kinetochore-microtubule attachment site. Nat. Cell Biol. 2006, 8, 581-585. [CrossRef] [PubMed]

107. Pot, I.; Measday, V.; Snydsman, B.; Cagney, G.; Fields, S.; Davis, T.N.; Muller, E.G.; Hieter, P. Chl4p and iml3p are two new members of the budding yeast outer kinetochore. Mol. Biol. Cell 2003, 14, 460-476. [CrossRef] [PubMed]

108. Hinshaw, S.M.; Harrison, S.C. An Iml3-Chl4 heterodimer links the core centromere to factors required for accurate chromosome segregation. Cell Rep. 2013, 5, 29-36. [CrossRef] [PubMed]

109. McKinley, K.L.; Sekulic, N.; Guo, L.Y.; Tsinman, T.; Black, B.E.; Cheeseman, I.M. The CENP-L-N Complex Forms a Critical Node in an Integrated Meshwork of Interactions at the Centromere-Kinetochore Interface. Mol. Cell 2015, 60, 886-898. [CrossRef] [PubMed]

110. Weir, J.R.; Faesen, A.C.; Klare, K.; Petrovic, A.; Basilico, F.; Fischbock, J.; Pentakota, S.; Keller, J.; Pesenti, M.E.; Pan, D.; et al. Insights from biochemical reconstitution into the architecture of human kinetochores. Nature 2016, 537, 249-253. [CrossRef] [PubMed]

111. Basilico, F.; Maffini, S.; Weir, J.R.; Prumbaum, D.; Rojas, A.M.; Zimniak, T.; De Antoni, A.; Jeganathan, S.; Voss, B.; van Gerwen, S.; et al. The pseudo gtpase cenp-m drives human kinetochore assembly. eLife 2014, 3, e02978. [CrossRef] [PubMed]

112. Okada, M.; Okawa, K.; Isobe, T.; Fukagawa, T. Cenp-h-containing complex facilitates centromere deposition of cenp-a in cooperation with fact and chd1. Mol. Biol. Cell 2009, 20, 3986-3995. [CrossRef] [PubMed]

113. Pekgoz Altunkaya, G.; Malvezzi, F.; Demianova, Z.; Zimniak, T.; Litos, G.; Weissmann, F.; Mechtler, K.; Herzog, F.; Westermann, S. Ccan assembly configures composite binding interfaces to promote cross-linking of ndc80 complexes at the kinetochore. Curr. Biol. 2016, 26, 2370-2378. [CrossRef] [PubMed]

114. Measday, V.; Hailey, D.W.; Pot, I.; Givan, S.A.; Hyland, K.M.; Cagney, G.; Fields, S.; Davis, T.N.; Hieter, P. $\mathrm{Ctf} 3 \mathrm{p}$, the mis6 budding yeast homolog, interacts with mcm22p and mcm16p at the yeast outer kinetochore. Genes Dev. 2002, 16, 101-113. [CrossRef] [PubMed]

115. De Wulf, P.; McAinsh, A.D.; Sorger, P.K. Hierarchical assembly of the budding yeast kinetochore from multiple subcomplexes. Genes Dev. 2003, 17, 2902-2921. [CrossRef] [PubMed]

116. Schmitzberger, F.; Harrison, S.C. RWD domain: A recurring module in kinetochore architecture shown by a Ctf19-Mcm21 complex structure. EMBO Rep. 2012, 13, 216-222. [CrossRef] [PubMed]

117. Ortiz, J.; Stemmann, O.; Rank, S.; Lechner, J. A putative protein complex consisting of Ctf19, Mcm21, and Okp1 represents a missing link in the budding yeast kinetochore. Genes Dev. 1999, 13, 1140-1155. [CrossRef] [PubMed]

118. Meluh, P.B.; Koshland, D. Evidence that the MIF2 gene of Saccharomyces cerevisiae encodes a centromere protein with homology to the mammalian centromere protein CENP-C. Mol. Biol. Cell 1995, 6, $793-807$. [CrossRef] [PubMed]

119. Akiyoshi, B.; Nelson, C.R.; Ranish, J.A.; Biggins, S. Quantitative proteomic analysis of purified yeast kinetochores identifies a PP1 regulatory subunit. Genes Dev. 2009, 23, 2887-2899. [CrossRef] [PubMed]

120. Cole, H.A.; Howard, B.H.; Clark, D.J. The centromeric nucleosome of budding yeast is perfectly positioned and covers the entire centromere. Proc. Natl. Acad. Sci. USA 2011, 108, 12687-12692. [CrossRef] [PubMed]

121. Meluh, P.B.; Yang, P.; Glowczewski, L.; Koshland, D.; Smith, M.M. Cse4p is a component of the core centromere of Saccharomyces cerevisiae. Cell 1998, 94, 607-613. [CrossRef]

122. Furuyama, S.; Biggins, S. Centromere identity is specified by a single centromeric nucleosome in budding yeast. Proc. Natl. Acad. Sci. USA 2007, 104, 14706-14711. [CrossRef] [PubMed]

123. Bram, R.J.; Kornberg, R.D. Isolation of a Saccharomyces cerevisiae centromere DNA-binding protein, its human homolog, and its possible role as a transcription factor. Mol. Cell. Biol. 1987, 7, 403-409. [CrossRef] [PubMed]

124. Espelin, C.W.; Kaplan, K.B.; Sorger, P.K. Probing the architecture of a simple kinetochore using DNA-protein crosslinking. J. Cell Biol. 1997, 139, 1383-1396. [CrossRef] [PubMed] 
125. Cheeseman, I.M.; Drubin, D.G.; Barnes, G. Simple centromere, complex kinetochore: Linking spindle microtubules and centromeric DNA in budding yeast. J. Cell Biol. 2002, 157, 199-203. [CrossRef] [PubMed]

126. Hemmerich, P.; Stoyan, T.; Wieland, G.; Koch, M.; Lechner, J.; Diekmann, S. Interaction of yeast kinetochore proteins with centromere-protein/transcription factor Cbf1. Proc. Natl. Acad. Sci. USA 2000, 97, 12583-12588. [CrossRef] [PubMed]

127. Krassovsky, K.; Henikoff, J.G.; Henikoff, S. Tripartite organization of centromeric chromatin in budding yeast. Proc. Natl. Acad. Sci. USA 2012, 109, 243-248. [CrossRef] [PubMed]

128. Cho, U.S.; Harrison, S.C. Ndc10 is a platform for inner kinetochore assembly in budding yeast. Nat. Struct. Mol. Biol. 2012, 19, 48-55. [CrossRef] [PubMed]

129. Xiao, H.; Mizuguchi, G.; Wisniewski, J.; Huang, Y.; Wei, D.; Wu, C. Nonhistone Scm3 binds to AT-rich DNA to organize atypical centromeric nucleosome of budding yeast. Mol. Cell 2011, 43, 369-380. [CrossRef] [PubMed]

130. Furuyama, T.; Henikoff, S. Centromeric nucleosomes induce positive DNA supercoils. Cell 2009, 138, $104-113$. [CrossRef] [PubMed]

131. Huang, C.C.; Chang, K.M.; Cui, H.; Jayaram, M. Histone H3-variant Cse4-induced positive DNA supercoiling in the yeast plasmid has implications for a plasmid origin of a chromosome centromere. Proc. Natl. Acad. Sci. USA 2011, 108, 13671-13676. [CrossRef] [PubMed]

132. Diaz-Ingelmo, O.; Martinez-Garcia, B.; Segura, J.; Valdes, A.; Roca, J. DNA Topology and Global Architecture of Point Centromeres. Cell Rep. 2015, 13, 667-677. [CrossRef] [PubMed]

133. Drinnenberg, I.A.; Henikoff, S.; Malik, H.S. Evolutionary Turnover of Kinetochore Proteins: A Ship of Theseus? Trends Cell Biol. 2016, 26, 498-510. [CrossRef] [PubMed]

134. Palmer, D.K.; Margolis, R.L. Kinetochore components recognized by human autoantibodies are present on mononucleosomes. Mol. Cell. Biol. 1985, 5, 173-186. [CrossRef] [PubMed]

135. Shelby, R.D.; Vafa, O.; Sullivan, K.F. Assembly of CENP-A into centromeric chromatin requires a cooperative array of nucleosomal DNA contact sites. J. Cell Biol. 1997, 136, 501-513. [CrossRef] [PubMed]

136. Yoda, K.; Ando, S.; Morishita, S.; Houmura, K.; Hashimoto, K.; Takeyasu, K.; Okazaki, T. Human centromere protein a (cenp-a) can replace histone h3 in nucleosome reconstitution in vitro. Proc. Natl. Acad. Sci. USA 2000, 97, 7266-7271. [CrossRef] [PubMed]

137. Tachiwana, H.; Kagawa, W.; Shiga, T.; Osakabe, A.; Miya, Y.; Saito, K.; Hayashi-Takanaka, Y.; Oda, T.; Sato, M.; Park, S.Y.; et al. Crystal structure of the human centromeric nucleosome containing cenp-a. Nature 2011, 476, 232-235. [CrossRef] [PubMed]

138. Kingston, I.J.; Yung, J.S.; Singleton, M.R. Biophysical characterization of the centromere-specific nucleosome from budding yeast. J. Biol. Chem. 2011, 286, 4021-4026. [CrossRef] [PubMed]

139. Black, B.E.; Foltz, D.R.; Chakravarthy, S.; Luger, K.; Woods, V.L., Jr.; Cleveland, D.W. Structural determinants for generating centromeric chromatin. Nature 2004, 430, 578-582. [CrossRef] [PubMed]

140. Falk, S.J.; Lee, J.; Sekulic, N.; Sennett, M.A.; Lee, T.H.; Black, B.E. CENP-C directs a structural transition of CENP-A nucleosomes mainly through sliding of DNA gyres. Nat. Struct. Mol. Biol. 2016, 23, $204-208$. [CrossRef] [PubMed]

141. Falk, S.J.; Guo, L.Y.; Sekulic, N.; Smoak, E.M.; Mani, T.; Logsdon, G.A.; Gupta, K.; Jansen, L.E.; Van Duyne, G.D.; Vinogradov, S.A.; et al. Chromosomes. Cenp-c reshapes and stabilizes cenp-a nucleosomes at the centromere. Science 2015, 348, 699-703. [CrossRef] [PubMed]

142. Sekulic, N.; Bassett, E.A.; Rogers, D.J.; Black, B.E. The structure of (CENP-A-H4)(2) reveals physical features that mark centromeres. Nature 2010, 467, 347-351. [CrossRef] [PubMed]

143. Conde e Silva, N.; Black, B.E.; Sivolob, A.; Filipski, J.; Cleveland, D.W.; Prunell, A. CENP-A-containing nucleosomes: Easier disassembly versus exclusive centromeric localization. J. Mol. Biol. 2007, 370, 555-573. [CrossRef] [PubMed]

144. Black, B.E.; Brock, M.A.; Bedard, S.; Woods, V.L., Jr.; Cleveland, D.W. An epigenetic mark generated by the incorporation of CENP-A into centromeric nucleosomes. Proc. Natl. Acad. Sci. USA 2007, 104, 5008-5013. [CrossRef] [PubMed]

145. Panchenko, T.; Sorensen, T.C.; Woodcock, C.L.; Kan, Z.Y.; Wood, S.; Resch, M.G.; Luger, K.; Englander, S.W.; Hansen, J.C.; Black, B.E. Replacement of histone h3 with cenp-a directs global nucleosome array condensation and loosening of nucleosome superhelical termini. Proc. Natl. Acad. Sci. USA 2011, 108, 16588-16593. [CrossRef] [PubMed] 
146. Hasson, D.; Panchenko, T.; Salimian, K.J.; Salman, M.U.; Sekulic, N.; Alonso, A.; Warburton, P.E.; Black, B.E. The octamer is the major form of cenp-a nucleosomes at human centromeres. Nat. Struct. Mol. Biol. 2013, 20, 687-695. [CrossRef] [PubMed]

147. Miell, M.D.; Fuller, C.J.; Guse, A.; Barysz, H.M.; Downes, A.; Owen-Hughes, T.; Rappsilber, J.; Straight, A.F.; Allshire, R.C. Cenp-a confers a reduction in height on octameric nucleosomes. Nat. Struct. Mol. Biol. 2013, 20, 763-765. [CrossRef] [PubMed]

148. Black, B.E.; Cleveland, D.W. Epigenetic centromere propagation and the nature of CENP-a nucleosomes. Cell 2011, 144, 471-479. [CrossRef] [PubMed]

149. Padeganeh, A.; De Rop, V.; Maddox, P.S. Nucleosomal composition at the centromere: A numbers game. Chromosome Res. 2013, 21, 27-36. [CrossRef] [PubMed]

150. Carroll, C.W.; Silva, M.C.; Godek, K.M.; Jansen, L.E.; Straight, A.F. Centromere assembly requires the direct recognition of CENP-A nucleosomes by CENP-N. Nat. Cell Biol. 2009, 11, 896-902. [CrossRef] [PubMed]

151. Carroll, C.W.; Milks, K.J.; Straight, A.F. Dual recognition of CENP-A nucleosomes is required for centromere assembly. J. Cell Biol. 2010, 189, 1143-1155. [CrossRef] [PubMed]

152. Smoak, E.M.; Stein, P.; Schultz, R.M.; Lampson, M.A.; Black, B.E. Long-Term Retention of CENP-A Nucleosomes in Mammalian Oocytes Underpins Transgenerational Inheritance of Centromere Identity. Curr. Biol. 2016, 26, 1110-1116. [CrossRef] [PubMed]

153. Jansen, L.E.; Black, B.E.; Foltz, D.R.; Cleveland, D.W. Propagation of centromeric chromatin requires exit from mitosis. J. Cell Biol. 2007, 176, 795-805. [CrossRef] [PubMed]

154. Westhorpe, F.G.; Fuller, C.J.; Straight, A.F. A cell-free CENP-A assembly system defines the chromatin requirements for centromere maintenance. J. Cell Biol. 2015, 209, 789-801. [CrossRef] [PubMed]

155. Armache, K.J.; Garlick, J.D.; Canzio, D.; Narlikar, G.J.; Kingston, R.E. Structural basis of silencing: Sir3 BAH domain in complex with a nucleosome at 3.0 A resolution. Science 2011, 334, 977-982. [CrossRef] [PubMed]

156. Barbera, A.J.; Chodaparambil, J.V.; Kelley-Clarke, B.; Joukov, V.; Walter, J.C.; Luger, K.; Kaye, K.M. The nucleosomal surface as a docking station for kaposi's sarcoma herpesvirus lana. Science 2006, 311, 856-861. [CrossRef] [PubMed]

157. Makde, R.D.; England, J.R.; Yennawar, H.P.; Tan, S. Structure of RCC1 chromatin factor bound to the nucleosome core particle. Nature 2010, 467, 562-566. [CrossRef] [PubMed]

158. Tachiwana, H.; Muller, S.; Blumer, J.; Klare, K.; Musacchio, A.; Almouzni, G. HJURP involvement in de novo CenH3(CENP-A) and CENP-C recruitment. Cell Rep. 2015, 11, 22-32. [CrossRef] [PubMed]

159. Suzuki, N.; Nakano, M.; Nozaki, N.; Egashira, S.; Okazaki, T.; Masumoto, H. CENP-B interacts with CENP-C domains containing Mif2 regions responsible for centromere localization. J. Biol. Chem. 2004, 279, 5934-5946. [CrossRef] [PubMed]

160. Yang, C.H.; Tomkiel, J.; Saitoh, H.; Johnson, D.H.; Earnshaw, W.C. Identification of overlapping DNA-binding and centromere-targeting domains in the human kinetochore protein CENP-C. Mol. Cell. Biol. 1996, 16, 3576-3586. [CrossRef] [PubMed]

161. Politi, V.; Perini, G.; Trazzi, S.; Pliss, A.; Raska, I.; Earnshaw, W.C.; Della Valle, G. Cenp-c binds the alpha-satellite DNA in vivo at specific centromere domains. J. Cell Sci. 2002, 115, 2317-2327. [PubMed]

162. Trazzi, S.; Bernardoni, R.; Diolaiti, D.; Politi, V.; Earnshaw, W.C.; Perini, G.; Della Valle, G. In vivo functional dissection of human inner kinetochore protein cenp-c. J. Struct. Biol. 2002, 140, 39-48. [CrossRef]

163. Song, K.; Gronemeyer, B.; Lu, W.; Eugster, E.; Tomkiel, J.E. Mutational analysis of the central centromere targeting domain of human centromere protein C, (CENP-C). Exp. Cell Res. 2002, 275, 81-91. [CrossRef] [PubMed]

164. Lanini, L.; McKeon, F. Domains required for CENP-C assembly at the kinetochore. Mol. Biol. Cell 1995, 6, 1049-1059. [CrossRef] [PubMed]

165. Milks, K.J.; Moree, B.; Straight, A.F. Dissection of CENP-C-directed centromere and kinetochore assembly. Mol. Biol. Cell 2009, 20, 4246-4255. [CrossRef] [PubMed]

166. Tanaka, K.; Chang, H.L.; Kagami, A.; Watanabe, Y. CENP-C functions as a scaffold for effectors with essential kinetochore functions in mitosis and meiosis. Dev. Cell 2009, 17, 334-343. [CrossRef] [PubMed]

167. Cohen, R.L.; Espelin, C.W.; De Wulf, P.; Sorger, P.K.; Harrison, S.C.; Simons, K.T. Structural and functional dissection of Mif2p, a conserved DNA-binding kinetochore protein. Mol. Biol. Cell 2008, 19, 4480-4491. [CrossRef] [PubMed] 
168. Sugimoto, K.; Kuriyama, K.; Shibata, A.; Himeno, M. Characterization of internal DNA-binding and C-terminal dimerization domains of human centromere/kinetochore autoantigen CENP-C in vitro: Role of DNA-binding and self-associating activities in kinetochore organization. Chromosome Res. 1997, 5, 132-141. [CrossRef] [PubMed]

169. Bodor, D.L.; Mata, J.F.; Sergeev, M.; David, A.F.; Salimian, K.J.; Panchenko, T.; Cleveland, D.W.; Black, B.E.; Shah, J.V.; Jansen, L.E. The quantitative architecture of centromeric chromatin. eLife 2014, 3, e02137. [CrossRef] [PubMed]

170. Hori, T.; Shang, W.H.; Toyoda, A.; Misu, S.; Monma, N.; Ikeo, K.; Molina, O.; Vargiu, G.; Fujiyama, A.; Kimura, H.; et al. Histone h4 lys 20 monomethylation of the cenp-a nucleosome is essential for kinetochore assembly. Dev. Cell 2014, 29, 740-749. [CrossRef] [PubMed]

171. Bailey, A.O.; Panchenko, T.; Sathyan, K.M.; Petkowski, J.J.; Pai, P.J.; Bai, D.L.; Russell, D.H.; Macara, I.G.; Shabanowitz, J.; Hunt, D.F.; et al. Posttranslational modification of cenp-a influences the conformation of centromeric chromatin. Proc. Natl. Acad. Sci. USA 2013, 110, 11827-11832. [CrossRef] [PubMed]

172. Yan, Z.; Delannoy, M.; Ling, C.; Daee, D.; Osman, F.; Muniandy, P.A.; Shen, X.; Oostra, A.B.; Du, H.; Steltenpool, J.; et al. A histone-fold complex and fancm form a conserved DNA-remodeling complex to maintain genome stability. Mol. Cell 2010, 37, 865-878. [CrossRef] [PubMed]

173. Singh, T.R.; Saro, D.; Ali, A.M.; Zheng, X.F.; Du, C.H.; Killen, M.W.; Sachpatzidis, A.; Wahengbam, K.; Pierce, A.J.; Xiong, Y.; et al. Mhf1-mhf2, a histone-fold-containing protein complex, participates in the fanconi anemia pathway via fancm. Mol. Cell 2010, 37, 879-886. [CrossRef] [PubMed]

174. Huang, M.; Kim, J.M.; Shiotani, B.; Yang, K.; Zou, L.; D’Andrea, A.D. The FANCM/FAAP24 complex is required for the DNA interstrand crosslink-induced checkpoint response. Mol. Cell 2010, 39, 259-268. [CrossRef] [PubMed]

175. Nishino, T.; Takeuchi, K.; Gascoigne, K.E.; Suzuki, A.; Hori, T.; Oyama, T.; Morikawa, K.; Cheeseman, I.M.; Fukagawa, T. Cenp-t-w-s-x forms a unique centromeric chromatin structure with a histone-like fold. Cell 2012, 148, 487-501. [CrossRef]

176. Takeuchi, K.; Nishino, T.; Mayanagi, K.; Horikoshi, N.; Osakabe, A.; Tachiwana, H.; Hori, T.; Kurumizaka, H.; Fukagawa, T. The centromeric nucleosome-like cenp-t-w-s-x complex induces positive supercoils into DNA. Nucleic Acids Res. 2014, 42, 1644-1655. [CrossRef] [PubMed]

177. Prendergast, L.; van Vuuren, C.; Kaczmarczyk, A.; Doering, V.; Hellwig, D.; Quinn, N.; Hoischen, C.; Diekmann, S.; Sullivan, K.F. Premitotic assembly of human cenps -t and -w switches centromeric chromatin to a mitotic state. PLoS Biol. 2011, 9, e1001082. [CrossRef] [PubMed]

178. Samejima, I.; Spanos, C.; Alves Fde, L.; Hori, T.; Perpelescu, M.; Zou, J.; Rappsilber, J.; Fukagawa, T.; Earnshaw, W.C. Whole-proteome genetic analysis of dependencies in assembly of a vertebrate kinetochore. J. Cell Biol. 2015, 211, 1141-1156. [CrossRef] [PubMed]

179. Folco, H.D.; Campbell, C.S.; May, K.M.; Espinoza, C.A.; Oegema, K.; Hardwick, K.G.; Grewal, S.I.; Desai, A. The cenp-a n-tail confers epigenetic stability to centromeres via the cenp-t branch of the ccan in fission yeast. Curr. Biol. 2015, 25, 348-356. [CrossRef] [PubMed]

180. Hori, T.; Okada, M.; Maenaka, K.; Fukagawa, T. CENP-O class proteins form a stable complex and are required for proper kinetochore function. Mol. Biol. Cell 2008, 19, 843-854. [CrossRef]

181. Kagawa, N.; Hori, T.; Hoki, Y.; Hosoya, O.; Tsutsui, K.; Saga, Y.; Sado, T.; Fukagawa, T. The cenp-o complex requirement varies among different cell types. Chromosome Res. 2014, 22, 293-303. [CrossRef] [PubMed]

182. Bancroft, J.; Auckland, P.; Samora, C.P.; McAinsh, A.D. Chromosome congression is promoted by CENP-Qand CENP-E-dependent pathways. J. Cell Sci. 2015, 128, 171-184. [CrossRef] [PubMed]

183. Hua, S.; Wang, Z.; Jiang, K.; Huang, Y.; Ward, T.; Zhao, L.; Dou, Z.; Yao, X. Cenp-u cooperates with hec1 to orchestrate kinetochore-microtubule attachment. J. Biol. Chem. 2011, 286, 1627-1638. [CrossRef] [PubMed]

184. Amaro, A.C.; Samora, C.P.; Holtackers, R.; Wang, E.; Kingston, I.J.; Alonso, M.; Lampson, M.; McAinsh, A.D.; Meraldi, P. Molecular control of kinetochore-microtubule dynamics and chromosome oscillations. Nat. Cell Biol. 2010, 12, 319-329. [CrossRef] [PubMed]

185. Kang, Y.H.; Park, C.H.; Kim, T.S.; Soung, N.K.; Bang, J.K.; Kim, B.Y.; Park, J.E.; Lee, K.S. Mammalian polo-like kinase 1-dependent regulation of the pbip1-cenp-q complex at kinetochores. J. Biol. Chem. 2011, 286, 19744-19757. [CrossRef] [PubMed] 
186. Kang, Y.H.; Park, J.E.; Yu, L.R.; Soung, N.K.; Yun, S.M.; Bang, J.K.; Seong, Y.S.; Yu, H.; Garfield, S.; Veenstra, T.D.; et al. Self-regulated plk1 recruitment to kinetochores by the plk1-pbip1 interaction is critical for proper chromosome segregation. Mol. Cell 2006, 24, 409-422. [CrossRef] [PubMed]

187. Hyland, K.M.; Kingsbury, J.; Koshland, D.; Hieter, P. Ctf19p: A novel kinetochore protein in Saccharomyces cerevisiae and a potential link between the kinetochore and mitotic spindle. J. Cell Biol. 1999, 145, 15-28. [CrossRef] [PubMed]

188. Fernius, J.; Marston, A.L. Establishment of cohesion at the pericentromere by the Ctf19 kinetochore subcomplex and the replication fork-associated factor, Csm3. PLoS Genet. 2009, 5, e1000629. [CrossRef] [PubMed]

189. Ng, T.M.; Waples, W.G.; Lavoie, B.D.; Biggins, S. Pericentromeric sister chromatid cohesion promotes kinetochore biorientation. Mol. Biol. Cell 2009, 20, 3818-3827. [CrossRef] [PubMed]

190. Natsume, T.; Muller, C.A.; Katou, Y.; Retkute, R.; Gierlinski, M.; Araki, H.; Blow, J.J.; Shirahige, K.; Nieduszynski, C.A.; Tanaka, T.U. Kinetochores coordinate pericentromeric cohesion and early DNA replication by cdc7-dbf4 kinase recruitment. Mol. Cell 2013, 50, 661-674. [CrossRef] [PubMed]

191. Hornung, P.; Troc, P.; Malvezzi, F.; Maier, M.; Demianova, Z.; Zimniak, T.; Litos, G.; Lampert, F.; Schleiffer, A.; Brunner, M.; et al. A cooperative mechanism drives budding yeast kinetochore assembly downstream of cenp-a. J. Cell Biol. 2014, 206, 509-524. [CrossRef] [PubMed]

192. Masumoto, H.; Masukata, H.; Muro, Y.; Nozaki, N.; Okazaki, T. A human centromere antigen (CENP-B) interacts with a short specific sequence in alphoid DNA, a human centromeric satellite. J. Cell Biol. 1989, 109, 1963-1973. [CrossRef] [PubMed]

193. Smit, A.F.; Riggs, A.D. Tiggers and DNA transposon fossils in the human genome. Proc. Natl. Acad. Sci. USA 1996, 93, 1443-1448. [CrossRef] [PubMed]

194. Hudson, D.F.; Fowler, K.J.; Earle, E.; Saffery, R.; Kalitsis, P.; Trowell, H.; Hill, J.; Wreford, N.G.; de Kretser, D.M.; Cancilla, M.R.; et al. Centromere protein b null mice are mitotically and meiotically normal but have lower body and testis weights. J. Cell Biol. 1998, 141, 309-319. [CrossRef]

195. Kapoor, M.; Montes de Oca Luna, R.; Liu, G.; Lozano, G.; Cummings, C.; Mancini, M.; Ouspenski, I.; Brinkley, B.R.; May, G.S. The cenpb gene is not essential in mice. Chromosoma 1998, 107, 570-576. [CrossRef] [PubMed]

196. Perez-Castro, A.V.; Shamanski, F.L.; Meneses, J.J.; Lovato, T.L.; Vogel, K.G.; Moyzis, R.K.; Pedersen, R. Centromeric protein b null mice are viable with no apparent abnormalities. Dev. Biol. 1998, 201, 135-143. [CrossRef] [PubMed]

197. Okada, T.; Ohzeki, J.; Nakano, M.; Yoda, K.; Brinkley, W.R.; Larionov, V.; Masumoto, H. Cenp-b controls centromere formation depending on the chromatin context. Cell 2007, 131, 1287-1300. [CrossRef] [PubMed]

198. Ohzeki, J.; Nakano, M.; Okada, T.; Masumoto, H. CENP-B box is required for de novo centromere chromatin assembly on human alphoid DNA. J. Cell Biol. 2002, 159, 765-775. [CrossRef] [PubMed]

199. Fachinetti, D.; Han, J.S.; McMahon, M.A.; Ly, P.; Abdullah, A.; Wong, A.J.; Cleveland, D.W. DNA sequence-specific binding of cenp-b enhances the fidelity of human centromere function. Dev. Cell 2015, 33, 314-327. [CrossRef] [PubMed]

200. Hoffmann, S.; Dumont, M.; Barra, V.; Ly, P.; Nechemia-Arbely, Y.; McMahon, M.A.; Herve, S.; Cleveland, D.W.; Fachinetti, D. Cenp-a is dispensable for mitotic centromere function after initial centromere/kinetochore assembly. Cell Rep. 2016, 17, 2394-2404. [CrossRef] [PubMed]

201. Fujita, R.; Otake, K.; Arimura, Y.; Horikoshi, N.; Miya, Y.; Shiga, T.; Osakabe, A.; Tachiwana, H.; Ohzeki, J.; Larionov, V.; et al. Stable complex formation of cenp-b with the cenp-a nucleosome. Nucleic Acids Res. 2015, 43, 4909-4922. [CrossRef] [PubMed]

202. Bharadwaj, R.; Qi, W.; Yu, H. Identification of two novel components of the human NDC80 kinetochore complex. J. Biol. Chem. 2004, 279, 13076-13085. [CrossRef] [PubMed]

203. McCleland, M.L.; Gardner, R.D.; Kallio, M.J.; Daum, J.R.; Gorbsky, G.J.; Burke, D.J.; Stukenberg, P.T. The highly conserved ndc80 complex is required for kinetochore assembly, chromosome congression, and spindle checkpoint activity. Genes Dev. 2003, 17, 101-114. [CrossRef] [PubMed]

204. Desai, A.; Rybina, S.; Muller-Reichert, T.; Shevchenko, A.; Shevchenko, A.; Hyman, A.; Oegema, K. Knl-1 directs assembly of the microtubule-binding interface of the kinetochore in c. Elegans. Genes Dev. 2003, 17, 2421-2435. [CrossRef] [PubMed] 
205. Obuse, C.; Iwasaki, O.; Kiyomitsu, T.; Goshima, G.; Toyoda, Y.; Yanagida, M. A conserved Mis12 centromere complex is linked to heterochromatic HP1 and outer kinetochore protein Zwint-1. Nat. Cell Biol. 2004, 6, 1135-1141. [CrossRef] [PubMed]

206. Wigge, P.A.; Kilmartin, J.V. The Ndc80p complex from Saccharomyces cerevisiae contains conserved centromere components and has a function in chromosome segregation. J. Cell Biol. 2001, 152, 349-360. [CrossRef] [PubMed]

207. Westermann, S.; Cheeseman, I.M.; Anderson, S.; Yates, J.R., 3rd; Drubin, D.G.; Barnes, G. Architecture of the budding yeast kinetochore reveals a conserved molecular core. J. Cell Biol. 2003, 163, 215-222. [CrossRef] [PubMed]

208. Cheeseman, I.M.; Niessen, S.; Anderson, S.; Hyndman, F.; Yates, J.R., 3rd; Oegema, K.; Desai, A. A conserved protein network controls assembly of the outer kinetochore and its ability to sustain tension. Genes Dev. 2004, 18, 2255-2268. [CrossRef] [PubMed]

209. Cheeseman, I.M.; Chappie, J.S.; Wilson-Kubalek, E.M.; Desai, A. The conserved KMN network constitutes the core microtubule-binding site of the kinetochore. Cell 2006, 127, 983-997. [CrossRef]

210. Nekrasov, V.S.; Smith, M.A.; Peak-Chew, S.; Kilmartin, J.V. Interactions between centromere complexes in Saccharomyces cerevisiae. Mol. Biol. Cell 2003, 14, 4931-4946. [CrossRef] [PubMed]

211. Pinsky, B.A.; Tatsutani, S.Y.; Collins, K.A.; Biggins, S. An Mtw1 complex promotes kinetochore biorientation that is monitored by the Ipl1/Aurora protein kinase. Dev. Cell 2003, 5, 735-745. [CrossRef]

212. Kline, S.L.; Cheeseman, I.M.; Hori, T.; Fukagawa, T.; Desai, A. The human Mis12 complex is required for kinetochore assembly and proper chromosome segregation. J. Cell Biol. 2006, 173, 9-17. [CrossRef] [PubMed]

213. DeLuca, J.G.; Gall, W.E.; Ciferri, C.; Cimini, D.; Musacchio, A.; Salmon, E.D. Kinetochore microtubule dynamics and attachment stability are regulated by Hec1. Cell 2006, 127, 969-982. [CrossRef] [PubMed]

214. Wei, R.R.; Schnell, J.R.; Larsen, N.A.; Sorger, P.K.; Chou, J.J.; Harrison, S.C. Structure of a central component of the yeast kinetochore: The Spc24p/Spc25p globular domain. Structure 2006, 14, 1003-1009. [CrossRef] [PubMed]

215. Wei, R.R.; Sorger, P.K.; Harrison, S.C. Molecular organization of the Ndc80 complex, an essential kinetochore component. Proc. Natl. Acad. Sci. USA 2005, 102, 5363-5367. [CrossRef] [PubMed]

216. Wei, R.R.; Al-Bassam, J.; Harrison, S.C. The Ndc80/HEC1 complex is a contact point for kinetochore-microtubule attachment. Nat. Struct. Mol. Biol. 2007, 14, 54-59. [CrossRef] [PubMed]

217. Ciferri, C.; De Luca, J.; Monzani, S.; Ferrari, K.J.; Ristic, D.; Wyman, C.; Stark, H.; Kilmartin, J.; Salmon, E.D.; Musacchio, A. Architecture of the human ndc80-hec1 complex, a critical constituent of the outer kinetochore. J. Biol. Chem. 2005, 280, 29088-29095. [CrossRef] [PubMed]

218. Ciferri, C.; Pasqualato, S.; Screpanti, E.; Varetti, G.; Santaguida, S.; Dos Reis, G.; Maiolica, A.; Polka, J.; De Luca, J.G.; De Wulf, P.; et al. Implications for kinetochore-microtubule attachment from the structure of an engineered ndc80 complex. Cell 2008, 133, 427-439. [CrossRef] [PubMed]

219. Valverde, R.; Ingram, J.; Harrison, S.C. Conserved Tetramer Junction in the Kinetochore Ndc80 Complex. Cell Rep. 2016, 17, 1915-1922. [CrossRef] [PubMed]

220. Schou, K.B.; Andersen, J.S.; Pedersen, L.B. A divergent calponin homology (NN-CH) domain defines a novel family: Implications for evolution of ciliary IFT complex B proteins. Bioinformatics 2014, 30, 899-902. [CrossRef] [PubMed]

221. Alushin, G.M.; Ramey, V.H.; Pasqualato, S.; Ball, D.A.; Grigorieff, N.; Musacchio, A.; Nogales, E. The ndc80 kinetochore complex forms oligomeric arrays along microtubules. Nature 2010, 467, 805-810. [CrossRef] [PubMed]

222. Alushin, G.M.; Musinipally, V.; Matson, D.; Tooley, J.; Stukenberg, P.T.; Nogales, E. Multimodal microtubule binding by the Ndc80 kinetochore complex. Nat. Struct. Mol. Biol. 2012, 19, 1161-1167. [CrossRef] [PubMed]

223. DeLuca, J.G.; Musacchio, A. Structural organization of the kinetochore-microtubule interface. Curr. Opin. Cell Biol. 2012, 24, 48-56. [CrossRef] [PubMed]

224. DeLuca, K.F.; Lens, S.M.; DeLuca, J.G. Temporal changes in Hec1 phosphorylation control kinetochore-microtubule attachment stability during mitosis. J. Cell Sci. 2011, 124, 622-634. [CrossRef] [PubMed]

225. Miller, S.A.; Johnson, M.L.; Stukenberg, P.T. Kinetochore attachments require an interaction between unstructured tails on microtubules and Ndc80(Hec1). Curr. Biol. 2008, 18, 1785-1791. [CrossRef] [PubMed] 
226. Guimaraes, G.J.; Dong, Y.; McEwen, B.F.; Deluca, J.G. Kinetochore-microtubule attachment relies on the disordered N-terminal tail domain of Hec1. Curr. Biol. 2008, 18, 1778-1784. [CrossRef] [PubMed]

227. Umbreit, N.T.; Gestaut, D.R.; Tien, J.F.; Vollmar, B.S.; Gonen, T.; Asbury, C.L.; Davis, T.N. The ndc80 kinetochore complex directly modulates microtubule dynamics. Proc. Natl. Acad. Sci. USA 2012, 109, 16113-16118. [CrossRef] [PubMed]

228. Aravamudhan, P.; Felzer-Kim, I.; Gurunathan, K.; Joglekar, A.P. Assembling the protein architecture of the budding yeast kinetochore-microtubule attachment using FRET. Curr. Biol. 2014, 24, 1437-1446. [CrossRef] [PubMed]

229. Zaytsev, A.V.; Mick, J.E.; Maslennikov, E.; Nikashin, B.; DeLuca, J.G.; Grishchuk, E.L. Multisite phosphorylation of the NDC80 complex gradually tunes its microtubule-binding affinity. Mol. Biol. Cell 2015, 26, 1829-1844. [CrossRef] [PubMed]

230. Kemmler, S.; Stach, M.; Knapp, M.; Ortiz, J.; Pfannstiel, J.; Ruppert, T.; Lechner, J. Mimicking ndc80 phosphorylation triggers spindle assembly checkpoint signalling. EMBO J. 2009, 28, 1099-1110. [CrossRef] [PubMed]

231. Lampert, F.; Mieck, C.; Alushin, G.M.; Nogales, E.; Westermann, S. Molecular requirements for the formation of a kinetochore-microtubule interface by Dam1 and Ndc80 complexes. J. Cell Biol. 2013, 200, 21-30. [CrossRef] [PubMed]

232. Cheerambathur, D.K.; Gassmann, R.; Cook, B.; Oegema, K.; Desai, A. Crosstalk between microtubule attachment complexes ensures accurate chromosome segregation. Science 2013, 342, 1239-1242. [CrossRef] [PubMed]

233. Zaytsev, A.V.; Sundin, L.J.; DeLuca, K.F.; Grishchuk, E.L.; DeLuca, J.G. Accurate phosphoregulation of kinetochore-microtubule affinity requires unconstrained molecular interactions. J. Cell Biol. 2014, 206, 45-59. [CrossRef] [PubMed]

234. Petrovic, A.; Pasqualato, S.; Dube, P.; Krenn, V.; Santaguida, S.; Cittaro, D.; Monzani, S.; Massimiliano, L.; Keller, J.; Tarricone, A.; et al. The mis12 complex is a protein interaction hub for outer kinetochore assembly. J. Cell Biol. 2010, 190, 835-852. [CrossRef] [PubMed]

235. Petrovic, A.; Mosalaganti, S.; Keller, J.; Mattiuzzo, M.; Overlack, K.; Krenn, V.; De Antoni, A.; Wohlgemuth, S.; Cecatiello, V.; Pasqualato, S.; et al. Modular assembly of rwd domains on the mis12 complex underlies outer kinetochore organization. Mol. Cell 2014, 53, 591-605. [CrossRef] [PubMed]

236. Maskell, D.P.; Hu, X.W.; Singleton, M.R. Molecular architecture and assembly of the yeast kinetochore mind complex. J. Cell Biol. 2010, 190, 823-834. [CrossRef] [PubMed]

237. Hornung, P.; Maier, M.; Alushin, G.M.; Lander, G.C.; Nogales, E.; Westermann, S. Molecular architecture and connectivity of the budding yeast mtw1 kinetochore complex. J. Mol. Biol. 2011, 405, 548-559. [CrossRef] [PubMed]

238. Screpanti, E.; De Antoni, A.; Alushin, G.M.; Petrovic, A.; Melis, T.; Nogales, E.; Musacchio, A. Direct binding of cenp-c to the mis12 complex joins the inner and outer kinetochore. Curr. Biol. 2011, 21, 391-398. [CrossRef] [PubMed]

239. Huis in 't Veld, P.J.; Jeganathan, S.; Petrovic, A.; John, J.; Singh, P.; Weissmann, F.; Bange, T.; Musacchio, A. Molecular basis of outer kinetochore assembly on cenp-t. eLife 2016. [CrossRef] [PubMed]

240. Dimitrova, Y.N.; Jenni, S.; Valverde, R.; Khin, Y.; Harrison, S.C. Structure of the mind complex defines a regulatory focus for yeast kinetochore assembly. Cell 2016, 167, 1014-1027. [CrossRef] [PubMed]

241. Petrovic, A.; Keller, J.; Liu, Y.; Overlack, K.; John, J.; Dimitrova, Y.N.; Jenni, S.; van Gerwen, S.; Stege, P.; Wohlgemuth, S.; et al. Structure of the mis12 complex and molecular basis of its interaction with cenp-c at human kinetochores. Cell 2016, 167, 1028-1040. [CrossRef] [PubMed]

242. Malvezzi, F.; Litos, G.; Schleiffer, A.; Heuck, A.; Mechtler, K.; Clausen, T.; Westermann, S. A structural basis for kinetochore recruitment of the ndc 80 complex via two distinct centromere receptors. EMBO J. 2013, 32, 409-423. [CrossRef] [PubMed]

243. Przewloka, M.R.; Zhang, W.; Costa, P.; Archambault, V.; D’Avino, P.P.; Lilley, K.S.; Laue, E.D.; McAinsh, A.D.; Glover, D.M. Molecular analysis of core kinetochore composition and assembly in Drosophila melanogaster. PLoS ONE 2007, 2, e478. [CrossRef] [PubMed]

244. Schittenhelm, R.B.; Heeger, S.; Althoff, F.; Walter, A.; Heidmann, S.; Mechtler, K.; Lehner, C.F. Spatial organization of a ubiquitous eukaryotic kinetochore protein network in drosophila chromosomes. Chromosoma 2007, 116, 385-402. [CrossRef] [PubMed] 
245. Liu, Y.; Petrovic, A.; Rombaut, P.; Mosalaganti, S.; Keller, J.; Raunser, S.; Herzog, F.; Musacchio, A. Insights from the reconstitution of the divergent outer kinetochore of Drosophila melanogaster. Open Biol. 2016, 6. [CrossRef] [PubMed]

246. Richter, M.M.; Poznanski, J.; Zdziarska, A.; Czarnocki-Cieciura, M.; Lipinszki, Z.; Dadlez, M.; Glover, D.M.; Przewloka, M.R. Network of protein interactions within the drosophila inner kinetochore. Open Biol. 2016, 6. [CrossRef] [PubMed]

247. Morelli, E.; Mastrodonato, V.; Beznoussenko, G.V.; Mironov, A.A.; Tognon, E.; Vaccari, T. An essential step of kinetochore formation controlled by the snare protein snap29. EMBO J. 2016, 35, 2223-2237. [CrossRef] [PubMed]

248. Tromer, E.; Snel, B.; Kops, G.J. Widespread recurrent patterns of rapid repeat evolution in the kinetochore scaffold knl1. Genome Biol. Evol. 2015, 7, 2383-2393. [CrossRef] [PubMed]

249. Koshland, D.E.; Mitchison, T.J.; Kirschner, M.W. Polewards chromosome movement driven by microtubule depolymerization in vitro. Nature 1988, 331, 499-504. [CrossRef] [PubMed]

250. Coue, M.; Lombillo, V.A.; McIntosh, J.R. Microtubule depolymerization promotes particle and chromosome movement in vitro. J. Cell Biol. 1991, 112, 1165-1175. [CrossRef] [PubMed]

251. Grishchuk, E.L.; Molodtsov, M.I.; Ataullakhanov, F.I.; McIntosh, J.R. Force production by disassembling microtubules. Nature 2005, 438, 384-388. [CrossRef] [PubMed]

252. Powers, A.F.; Franck, A.D.; Gestaut, D.R.; Cooper, J.; Gracyzk, B.; Wei, R.R.; Wordeman, L.; Davis, T.N.; Asbury, C.L. The ndc 80 kinetochore complex forms load-bearing attachments to dynamic microtubule tips via biased diffusion. Cell 2009, 136, 865-875. [CrossRef] [PubMed]

253. Schmidt, J.C.; Arthanari, H.; Boeszoermenyi, A.; Dashkevich, N.M.; Wilson-Kubalek, E.M.; Monnier, N.; Markus, M.; Oberer, M.; Milligan, R.A.; Bathe, M.; et al. The kinetochore-bound ska1 complex tracks depolymerizing microtubules and binds to curved protofilaments. Dev. Cell 2012, 23, 968-980. [CrossRef] [PubMed]

254. Maiato, H.; DeLuca, J.; Salmon, E.D.; Earnshaw, W.C. The dynamic kinetochore-microtubule interface. J. Cell Sci. 2004, 117, 5461-5477. [CrossRef] [PubMed]

255. Maiato, H.; Gomes, A.M.; Sousa, F.; Barisic, M. Mechanisms of chromosome congression during mitosis. Biology (Basel) 2017.

256. Gaitanos, T.N.; Santamaria, A.; Jeyaprakash, A.A.; Wang, B.; Conti, E.; Nigg, E.A. Stable kinetochore-microtubule interactions depend on the ska complex and its new component ska3/c13orf3. EMBO J. 2009, 28, 1442-1452. [CrossRef] [PubMed]

257. Welburn, J.P.; Grishchuk, E.L.; Backer, C.B.; Wilson-Kubalek, E.M.; Yates, J.R., 3rd; Cheeseman, I.M. The human kinetochore ska1 complex facilitates microtubule depolymerization-coupled motility. Dev. Cell 2009, 16, 374-385. [CrossRef] [PubMed]

258. Theis, M.; Slabicki, M.; Junqueira, M.; Paszkowski-Rogacz, M.; Sontheimer, J.; Kittler, R.; Heninger, A.K.; Glatter, T.; Kruusmaa, K.; Poser, I.; et al. Comparative profiling identifies c13orf3 as a component of the ska complex required for mammalian cell division. EMBO J. 2009, 28, 1453-1465. [CrossRef] [PubMed]

259. Hofmann, C.; Cheeseman, I.M.; Goode, B.L.; McDonald, K.L.; Barnes, G.; Drubin, D.G. Saccharomyces cerevisiae duo1p and dam1p, novel proteins involved in mitotic spindle function. J. Cell Biol. 1998, 143, 1029-1040. [CrossRef] [PubMed]

260. Asbury, C.L.; Gestaut, D.R.; Powers, A.F.; Franck, A.D.; Davis, T.N. The dam1 kinetochore complex harnesses microtubule dynamics to produce force and movement. Proc. Natl. Acad. Sci. USA 2006, 103, 9873-9878. [CrossRef] [PubMed]

261. Grishchuk, E.L.; Efremov, A.K.; Volkov, V.A.; Spiridonov, I.S.; Gudimchuk, N.; Westermann, S.; Drubin, D.; Barnes, G.; McIntosh, J.R.; Ataullakhanov, F.I. The dam1 ring binds microtubules strongly enough to be a processive as well as energy-efficient coupler for chromosome motion. Proc. Natl. Acad. Sci. USA 2008, 105, 15423-15428. [CrossRef] [PubMed]

262. Grishchuk, E.L.; Spiridonov, I.S.; Volkov, V.A.; Efremov, A.; Westermann, S.; Drubin, D.; Barnes, G.; Ataullakhanov, F.I.; McIntosh, J.R. Different assemblies of the dam1 complex follow shortening microtubules by distinct mechanisms. Proc. Natl. Acad. Sci. USA 2008, 105, 6918-6923. [CrossRef] [PubMed]

263. Westermann, S.; Wang, H.W.; Avila-Sakar, A.; Drubin, D.G.; Nogales, E.; Barnes, G. The dam1 kinetochore ring complex moves processively on depolymerizing microtubule ends. Nature 2006, 440, 565-569. [CrossRef] [PubMed] 
264. Tien, J.F.; Umbreit, N.T.; Gestaut, D.R.; Franck, A.D.; Cooper, J.; Wordeman, L.; Gonen, T.; Asbury, C.L.; Davis, T.N. Cooperation of the dam 1 and ndc 80 kinetochore complexes enhances microtubule coupling and is regulated by aurora b. J. Cell Biol. 2010, 189, 713-723. [CrossRef] [PubMed]

265. Lampert, F.; Hornung, P.; Westermann, S. The dam1 complex confers microtubule plus end-tracking activity to the ndc80 kinetochore complex. J. Cell Biol. 2010, 189, 641-649. [CrossRef] [PubMed]

266. Cheeseman, I.M.; Anderson, S.; Jwa, M.; Green, E.M.; Kang, J.; Yates, J.R., 3rd; Chan, C.S.; Drubin, D.G.; Barnes, G. Phospho-regulation of kinetochore-microtubule attachments by the aurora kinase ipl1p. Cell 2002, 111, 163-172. [CrossRef]

267. Chan, Y.W.; Jeyaprakash, A.A.; Nigg, E.A.; Santamaria, A. Aurora b controls kinetochore-microtubule attachments by inhibiting ska complex-kmn network interaction. J. Cell Biol. 2012, 196, 563-571. [CrossRef] [PubMed]

268. Redli, P.M.; Gasic, I.; Meraldi, P.; Nigg, E.A.; Santamaria, A. The ska complex promotes aurora b activity to ensure chromosome biorientation. J. Cell Biol. 2016, 215, 77-93. [CrossRef] [PubMed]

269. Jeyaprakash, A.A.; Santamaria, A.; Jayachandran, U.; Chan, Y.W.; Benda, C.; Nigg, E.A.; Conti, E. Structural and functional organization of the ska complex, a key component of the kinetochore-microtubule interface. Mol. Cell 2012, 46, 274-286. [CrossRef] [PubMed]

270. Abad, M.A.; Medina, B.; Santamaria, A.; Zou, J.; Plasberg-Hill, C.; Madhumalar, A.; Jayachandran, U.; Redli, P.M.; Rappsilber, J.; Nigg, E.A.; et al. Structural basis for microtubule recognition by the human kinetochore ska complex. Nat. Commun. 2014, 5. [CrossRef] [PubMed]

271. Abad, M.A.; Zou, J.; Medina-Pritchard, B.; Nigg, E.A.; Rappsilber, J.; Santamaria, A.; Jeyaprakash, A.A. Ska3 ensures timely mitotic progression by interacting directly with microtubules and ska1 microtubule binding domain. Sci. Rep. 2016, 6. [CrossRef] [PubMed]

272. Miranda, J.J.; De Wulf, P.; Sorger, P.K.; Harrison, S.C. The yeast dash complex forms closed rings on microtubules. Nat. Struct. Mol. Biol. 2005, 12, 138-143. [CrossRef] [PubMed]

273. Westermann, S.; Avila-Sakar, A.; Wang, H.W.; Niederstrasser, H.; Wong, J.; Drubin, D.G.; Nogales, E.; Barnes, G. Formation of a dynamic kinetochore- microtubule interface through assembly of the dam 1 ring complex. Mol. Cell 2005, 17, 277-290. [CrossRef] [PubMed]

274. Ramey, V.H.; Wang, H.W.; Nakajima, Y.; Wong, A.; Liu, J.; Drubin, D.; Barnes, G.; Nogales, E. The dam1 ring binds to the e-hook of tubulin and diffuses along the microtubule. Mol. Biol. Cell 2011, 22, 457-466. [CrossRef] [PubMed]

275. Legal, T.; Zou, J.; Sochaj, A.; Rappsilber, J.; Welburn, J.P. Molecular architecture of the dam1 complex-microtubule interaction. Open Biol. 2016, 6. [CrossRef] [PubMed]

276. Wang, H.W.; Ramey, V.H.; Westermann, S.; Leschziner, A.E.; Welburn, J.P.; Nakajima, Y.; Drubin, D.G.; Barnes, G.; Nogales, E. Architecture of the dam1 kinetochore ring complex and implications for microtubule-driven assembly and force-coupling mechanisms. Nat. Struct. Mol. Biol. 2007, 14, 721-726. [CrossRef] [PubMed]

277. Ramey, V.H.; Wong, A.; Fang, J.; Howes, S.; Barnes, G.; Nogales, E. Subunit organization in the dam1 kinetochore complex and its ring around microtubules. Mol. Biol. Cell 2011, 22, 4335-4342. [CrossRef] [PubMed]

278. Przewloka, M.R.; Venkei, Z.; Bolanos-Garcia, V.M.; Debski, J.; Dadlez, M.; Glover, D.M. Cenp-c is a structural platform for kinetochore assembly. Curr. Biol. 2011, 21, 399-405. [CrossRef] [PubMed]

279. Gascoigne, K.E.; Takeuchi, K.; Suzuki, A.; Hori, T.; Fukagawa, T.; Cheeseman, I.M. Induced ectopic kinetochore assembly bypasses the requirement for cenp-a nucleosomes. Cell 2011, 145, 410-422. [CrossRef] [PubMed]

280. Rago, F.; Gascoigne, K.E.; Cheeseman, I.M. Distinct organization and regulation of the outer kinetochore kmn network downstream of cenp-c and cenp-t. Curr. Biol. 2015, 25, 671-677. [CrossRef] [PubMed]

281. Nishino, T.; Rago, F.; Hori, T.; Tomii, K.; Cheeseman, I.M.; Fukagawa, T. Cenp-t provides a structural platform for outer kinetochore assembly. EMBO J. 2013, 32, 424-436. [CrossRef] [PubMed]

282. Schleiffer, A.; Maier, M.; Litos, G.; Lampert, F.; Hornung, P.; Mechtler, K.; Westermann, S. Cenp-t proteins are conserved centromere receptors of the ndc80 complex. Nat. Cell Biol. 2012, 14, 604-613. [CrossRef] [PubMed]

283. Welburn, J.P.; Vleugel, M.; Liu, D.; Yates, J.R., 3rd; Lampson, M.A.; Fukagawa, T.; Cheeseman, I.M. Aurora b phosphorylates spatially distinct targets to differentially regulate the kinetochore-microtubule interface. Mol. Cell 2010, 38, 383-392. [CrossRef] [PubMed] 
284. Akiyoshi, B.; Nelson, C.R.; Biggins, S. The aurora b kinase promotes inner and outer kinetochore interactions in budding yeast. Genetics 2013, 194, 785-789. [CrossRef] [PubMed]

285. Yang, Y.; Wu, F.; Ward, T.; Yan, F.; Wu, Q.; Wang, Z.; McGlothen, T.; Peng, W.; You, T.; Sun, M.; et al. Phosphorylation of hsmis13 by aurora $b$ kinase is essential for assembly of functional kinetochore. J. Biol. Chem. 2008, 283, 26726-26736. [CrossRef] [PubMed]

286. Emanuele, M.J.; Lan, W.; Jwa, M.; Miller, S.A.; Chan, C.S.; Stukenberg, P.T. Aurora b kinase and protein phosphatase 1 have opposing roles in modulating kinetochore assembly. J. Cell Biol. 2008, 181, 241-254. [CrossRef] [PubMed]

287. Kim, S.; Yu, H. Multiple assembly mechanisms anchor the kmn spindle checkpoint platform at human mitotic kinetochores. J. Cell Biol. 2015, 208, 181-196. [CrossRef] [PubMed]

288. Suzuki, A.; Badger, B.L.; Salmon, E.D. A quantitative description of ndc80 complex linkage to human kinetochores. Nat. Commun. 2015, 6. [CrossRef] [PubMed]

289. Bock, L.J.; Pagliuca, C.; Kobayashi, N.; Grove, R.A.; Oku, Y.; Shrestha, K.; Alfieri, C.; Golfieri, C.; Oldani, A.; Dal Maschio, M.; et al. Cnn1 inhibits the interactions between the kmn complexes of the yeast kinetochore. Nat. Cell Biol. 2012, 14, 614-624. [CrossRef] [PubMed]

290. Akiyoshi, B.; Sarangapani, K.K.; Powers, A.F.; Nelson, C.R.; Reichow, S.L.; Arellano-Santoyo, H.; Gonen, T.; Ranish, J.A.; Asbury, C.L.; Biggins, S. Tension directly stabilizes reconstituted kinetochore-microtubule attachments. Nature 2010, 468, 576-579. [CrossRef] [PubMed]

291. Gonen, S.; Akiyoshi, B.; Iadanza, M.G.; Shi, D.; Duggan, N.; Biggins, S.; Gonen, T. The structure of purified kinetochores reveals multiple microtubule-attachment sites. Nat. Struct. Mol. Biol. 2012, 19, 925-929. [CrossRef] [PubMed]

292. Gascoigne, K.E.; Cheeseman, I.M. Cdk-dependent phosphorylation and nuclear exclusion coordinately control kinetochore assembly state. J. Cell Biol. 2013, 201, 23-32. [CrossRef] [PubMed]

293. Fukagawa, T.; Mikami, Y.; Nishihashi, A.; Regnier, V.; Haraguchi, T.; Hiraoka, Y.; Sugata, N.; Todokoro, K.; Brown, W.; Ikemura, T. Cenp-h, a constitutive centromere component, is required for centromere targeting of cenp-c in vertebrate cells. EMBO J. 2001, 20, 4603-4617. [CrossRef] [PubMed]

294. McClelland, S.E.; Borusu, S.; Amaro, A.C.; Winter, J.R.; Belwal, M.; McAinsh, A.D.; Meraldi, P. The cenp-a nac/cad kinetochore complex controls chromosome congression and spindle bipolarity. EMBO J. 2007, 26, 5033-5047. [CrossRef] [PubMed]

295. Hemmerich, P.; Weidtkamp-Peters, S.; Hoischen, C.; Schmiedeberg, L.; Erliandri, I.; Diekmann, S. Dynamics of inner kinetochore assembly and maintenance in living cells. J. Cell Biol. 2008, 180, 1101-1114. [CrossRef] [PubMed]

296. Kwon, M.S.; Hori, T.; Okada, M.; Fukagawa, T. Cenp-c is involved in chromosome segregation, mitotic checkpoint function, and kinetochore assembly. Mol. Biol. Cell 2007, 18, 2155-2168. [CrossRef] [PubMed]

297. Eskat, A.; Deng, W.; Hofmeister, A.; Rudolphi, S.; Emmerth, S.; Hellwig, D.; Ulbricht, T.; Doring, V.; Bancroft, J.M.; McAinsh, A.D.; et al. Step-wise assembly, maturation and dynamic behavior of the human cenp-p/o/r/q/u kinetochore sub-complex. PLoS ONE 2012, 7, e44717. [CrossRef] [PubMed]

298. Hellwig, D.; Emmerth, S.; Ulbricht, T.; Doring, V.; Hoischen, C.; Martin, R.; Samora, C.P.; McAinsh, A.D.; Carroll, C.W.; Straight, A.F.; et al. Dynamics of cenp-n kinetochore binding during the cell cycle. J. Cell Sci. 2011, 124, 3871-3883. [CrossRef] [PubMed]

299. Hellwig, D.; Munch, S.; Orthaus, S.; Hoischen, C.; Hemmerich, P.; Diekmann, S. Live-cell imaging reveals sustained centromere binding of cenp-t via cenp-a and cenp-b. J. Biophotonics 2008, 1, 245-254. [CrossRef] [PubMed]

300. McAinsh, A.D.; Meraldi, P.; Draviam, V.M.; Toso, A.; Sorger, P.K. The human kinetochore proteins nnf1r and $\mathrm{mcm} 21 \mathrm{r}$ are required for accurate chromosome segregation. EMBO J. 2006, 25, 4033-4049. [CrossRef] [PubMed]

301. Ohta, S.; Kimura, M.; Takagi, S.; Toramoto, I.; Ishihama, Y. Identification of mitosis-specific phosphorylation in mitotic chromosome-associated proteins. J Proteome Res 2016, 15, 3331-3341. [CrossRef] [PubMed]

302. Cheeseman, I.M.; Hori, T.; Fukagawa, T.; Desai, A. Knl1 and the cenp-h/i/k complex coordinately direct kinetochore assembly in vertebrates. Mol. Biol. Cell 2008, 19, 587-594. [CrossRef] [PubMed]

303. Venkei, Z.; Przewloka, M.R.; Ladak, Y.; Albadri, S.; Sossick, A.; Juhasz, G.; Novak, B.; Glover, D.M. Spatiotemporal dynamics of spc105 regulates the assembly of the drosophila kinetochore. Open Biol. 2012, 2. [CrossRef] [PubMed] 
304. Magidson, V.; O'Connell, C.B.; Loncarek, J.; Paul, R.; Mogilner, A.; Khodjakov, A. The spatial arrangement of chromosomes during prometaphase facilitates spindle assembly. Cell 2011, 146, 555-567. [CrossRef] [PubMed]

305. Karess, R. Rod-zw10-zwilch: A key player in the spindle checkpoint. Trends Cell Biol. 2005, 15, $386-392$. [CrossRef] [PubMed]

306. Civril, F.; Wehenkel, A.; Giorgi, F.M.; Santaguida, S.; Di Fonzo, A.; Grigorean, G.; Ciccarelli, F.D.; Musacchio, A. Structural analysis of the rzz complex reveals common ancestry with multisubunit vesicle tethering machinery. Structure 2010, 18, 616-626. [CrossRef] [PubMed]

307. McKenney, R.J.; Huynh, W.; Tanenbaum, M.E.; Bhabha, G.; Vale, R.D. Activation of cytoplasmic dynein motility by dynactin-cargo adapter complexes. Science 2014, 345, 337-341. [CrossRef] [PubMed]

308. Barisic, M.; Sohm, B.; Mikolcevic, P.; Wandke, C.; Rauch, V.; Ringer, T.; Hess, M.; Bonn, G.; Geley, S. Spindly/ccdc99 is required for efficient chromosome congression and mitotic checkpoint regulation. Mol. Biol. Cell 2010, 21, 1968-1981. [CrossRef] [PubMed]

309. Chan, Y.W.; Fava, L.L.; Uldschmid, A.; Schmitz, M.H.; Gerlich, D.W.; Nigg, E.A.; Santamaria, A. Mitotic control of kinetochore-associated dynein and spindle orientation by human spindly. J. Cell Biol. 2009, 185, 859-874. [CrossRef] [PubMed]

310. Gassmann, R.; Essex, A.; Hu, J.S.; Maddox, P.S.; Motegi, F.; Sugimoto, A.; O’Rourke, S.M.; Bowerman, B.; McLeod, I.; Yates, J.R., 3rd; et al. A new mechanism controlling kinetochore-microtubule interactions revealed by comparison of two dynein-targeting components: Spdl-1 and the rod/zwilch/zw10 complex. Genes Dev. 2008, 22, 2385-2399. [CrossRef] [PubMed]

311. Starr, D.A.; Williams, B.C.; Hays, T.S.; Goldberg, M.L. Zw10 helps recruit dynactin and dynein to the kinetochore. J. Cell Biol. 1998, 142, 763-774. [CrossRef] [PubMed]

312. Griffis, E.R.; Stuurman, N.; Vale, R.D. Spindly, a novel protein essential for silencing the spindle assembly checkpoint, recruits dynein to the kinetochore. J. Cell Biol. 2007, 177, 1005-1015. [CrossRef] [PubMed]

313. Yamamoto, T.G.; Watanabe, S.; Essex, A.; Kitagawa, R. Spdl-1 functions as a kinetochore receptor for mdf-1 in caenorhabditis elegans. J. Cell Biol. 2008, 183, 187-194. [CrossRef] [PubMed]

314. Holland, A.J.; Reis, R.M.; Niessen, S.; Pereira, C.; Andres, D.A.; Spielmann, H.P.; Cleveland, D.W.; Desai, A.; Gassmann, R. Preventing farnesylation of the dynein adaptor spindly contributes to the mitotic defects caused by farnesyltransferase inhibitors. Mol. Biol. Cell 2015, 26, 1845-1856. [CrossRef] [PubMed]

315. Moudgil, D.K.; Westcott, N.; Famulski, J.K.; Patel, K.; Macdonald, D.; Hang, H.; Chan, G.K. A novel role of farnesylation in targeting a mitotic checkpoint protein, human spindly, to kinetochores. J. Cell Biol. 2015, 208, 881-896. [CrossRef] [PubMed]

316. Hussein, D.; Taylor, S.S. Farnesylation of cenp-f is required for $\mathrm{g} 2 / \mathrm{m}$ progression and degradation after mitosis. J. Cell Sci. 2002, 115, 3403-3414. [PubMed]

317. Ashar, H.R.; James, L.; Gray, K.; Carr, D.; Black, S.; Armstrong, L.; Bishop, W.R.; Kirschmeier, P. Farnesyl transferase inhibitors block the farnesylation of cenp-e and cenp-f and alter the association of cenp-e with the microtubules. J. Biol. Chem. 2000, 275, 30451-30457. [CrossRef] [PubMed]

318. Basto, R.; Scaerou, F.; Mische, S.; Wojcik, E.; Lefebvre, C.; Gomes, R.; Hays, T.; Karess, R. In vivo dynamics of the rough deal checkpoint protein during drosophila mitosis. Curr. Biol. 2004, 14, 56-61. [CrossRef] [PubMed]

319. Howell, B.J.; McEwen, B.F.; Canman, J.C.; Hoffman, D.B.; Farrar, E.M.; Rieder, C.L.; Salmon, E.D. Cytoplasmic dynein/dynactin drives kinetochore protein transport to the spindle poles and has a role in mitotic spindle checkpoint inactivation. J. Cell Biol. 2001, 155, 1159-1172. [CrossRef] [PubMed]

320. Mische, S.; He, Y.; Ma, L.; Li, M.; Serr, M.; Hays, T.S. Dynein light intermediate chain: An essential subunit that contributes to spindle checkpoint inactivation. Mol. Biol. Cell 2008, 19, 4918-4929. [CrossRef] [PubMed]

321. Sivaram, M.V.; Wadzinski, T.L.; Redick, S.D.; Manna, T.; Doxsey, S.J. Dynein light intermediate chain 1 is required for progress through the spindle assembly checkpoint. EMBO J. 2009, 28, 902-914. [CrossRef] [PubMed]

322. Varma, D.; Monzo, P.; Stehman, S.A.; Vallee, R.B. Direct role of dynein motor in stable kinetochore-microtubule attachment, orientation, and alignment. J. Cell Biol. 2008, 182, 1045-1054. [CrossRef] [PubMed]

323. Williams, B.C.; Gatti, M.; Goldberg, M.L. Bipolar spindle attachments affect redistributions of zw10, a drosophila centromere/kinetochore component required for accurate chromosome segregation. J. Cell Biol. 1996, 134, 1127-1140. [CrossRef] [PubMed] 
324. Wojcik, E.; Basto, R.; Serr, M.; Scaerou, F.; Karess, R.; Hays, T. Kinetochore dynein: Its dynamics and role in the transport of the rough deal checkpoint protein. Nat. Cell Biol. 2001, 3, 1001-1007. [CrossRef] [PubMed]

325. Gassmann, R.; Holland, A.J.; Varma, D.; Wan, X.; Civril, F.; Cleveland, D.W.; Oegema, K.; Salmon, E.D.; Desai, A. Removal of spindly from microtubule-attached kinetochores controls spindle checkpoint silencing in human cells. Genes Dev. 2010, 24, 957-971. [CrossRef] [PubMed]

326. Buffin, E.; Lefebvre, C.; Huang, J.; Gagou, M.E.; Karess, R.E. Recruitment of mad2 to the kinetochore requires the rod/zw10 complex. Curr. Biol. 2005, 15, 856-861. [CrossRef] [PubMed]

327. Caldas, G.V.; Lynch, T.R.; Anderson, R.; Afreen, S.; Varma, D.; DeLuca, J.G. The rzz complex requires the n-terminus of knl1 to mediate optimal mad1 kinetochore localization in human cells. Open Biol. 2015, 5. [CrossRef] [PubMed]

328. Kops, G.J.; Kim, Y.; Weaver, B.A.; Mao, Y.; McLeod, I.; Yates, J.R., 3rd; Tagaya, M.; Cleveland, D.W. Zw10 links mitotic checkpoint signaling to the structural kinetochore. J. Cell Biol. 2005, 169, 49-60. [CrossRef] [PubMed]

329. Matson, D.R.; Stukenberg, P.T. Cenp-i and aurora b act as a molecular switch that ties rzz/mad1 recruitment to kinetochore attachment status. J. Cell Biol. 2014, 205, 541-554. [CrossRef] [PubMed]

330. Silio, V.; McAinsh, A.D.; Millar, J.B. Knl1-bubs and rzz provide two separable pathways for checkpoint activation at human kinetochores. Dev. Cell 2015, 35, 600-613. [CrossRef] [PubMed]

331. Zhang, G.; Lischetti, T.; Hayward, D.G.; Nilsson, J. Distinct domains in bub1 localize rzz and bubr1 to kinetochores to regulate the checkpoint. Nat. Commun. 2015, 6. [CrossRef] [PubMed]

332. Zinkowski, R.P.; Meyne, J.; Brinkley, B.R. The centromere-kinetochore complex: A repeat subunit model. J. Cell Biol. 1991, 113, 1091-1110. [CrossRef] [PubMed]

333. Joglekar, A.P.; Bouck, D.; Finley, K.; Liu, X.; Wan, Y.; Berman, J.; He, X.; Salmon, E.D.; Bloom, K.S. Molecular architecture of the kinetochore-microtubule attachment site is conserved between point and regional centromeres. J. Cell Biol. 2008, 181, 587-594. [CrossRef] [PubMed]

334. Lawrimore, J.; Bloom, K.S.; Salmon, E.D. Point centromeres contain more than a single centromere-specific cse4 (cenp-a) nucleosome. J. Cell Biol. 2011, 195, 573-582. [CrossRef] [PubMed]

335. Lando, D.; Endesfelder, U.; Berger, H.; Subramanian, L.; Dunne, P.D.; McColl, J.; Klenerman, D.; Carr, A.M.; Sauer, M.; Allshire, R.C.; et al. Quantitative single-molecule microscopy reveals that cenp-a(cnp1) deposition occurs during g2 in fission yeast. Open Biol. 2012, 2. [CrossRef] [PubMed]

336. Blower, M.D.; Sullivan, B.A.; Karpen, G.H. Conserved organization of centromeric chromatin in flies and humans. Dev. Cell 2002, 2, 319-330. [CrossRef]

337. Sullivan, B.A.; Karpen, G.H. Centromeric chromatin exhibits a histone modification pattern that is distinct from both euchromatin and heterochromatin. Nat. Struct. Mol. Biol. 2004, 11, 1076-1083. [CrossRef] [PubMed]

338. Ribeiro, S.A.; Vagnarelli, P.; Dong, Y.; Hori, T.; McEwen, B.F.; Fukagawa, T.; Flors, C.; Earnshaw, W.C. A super-resolution map of the vertebrate kinetochore. Proc. Natl. Acad. Sci. USA 2010, 107, 10484-10489. [CrossRef] [PubMed]

339. Lawrimore, J.; Vasquez, P.A.; Falvo, M.R.; Taylor, R.M., 2nd; Vicci, L.; Yeh, E.; Forest, M.G.; Bloom, K. DNA loops generate intracentromere tension in mitosis. J. Cell Biol. 2015, 210, 553-564. [CrossRef] [PubMed]

340. Stephens, A.D.; Quammen, C.W.; Chang, B.; Haase, J.; Taylor, R.M., 2nd; Bloom, K. The spatial segregation of pericentric cohesin and condensin in the mitotic spindle. Mol. Biol. Cell 2013, 24, 3909-3919. [CrossRef] [PubMed]

341. Stephens, A.D.; Haase, J.; Vicci, L.; Taylor, R.M., 2nd; Bloom, K. Cohesin, condensin, and the intramolecular centromere loop together generate the mitotic chromatin spring. J. Cell Biol. 2011, 193, 1167-1180. [CrossRef] [PubMed]

342. Gassmann, R.; Rechtsteiner, A.; Yuen, K.W.; Muroyama, A.; Egelhofer, T.; Gaydos, L.; Barron, F.; Maddox, P.; Essex, A.; Monen, J.; et al. An inverse relationship to germline transcription defines centromeric chromatin in c. Elegans. Nature 2012, 484, 534-537. [CrossRef] [PubMed]

343. Steiner, F.A.; Henikoff, S. Holocentromeres are dispersed point centromeres localized at transcription factor hotspots. eLife 2014, 3, e02025. [CrossRef] [PubMed]

344. Maddox, P.S.; Portier, N.; Desai, A.; Oegema, K. Molecular analysis of mitotic chromosome condensation using a quantitative time-resolved fluorescence microscopy assay. Proc. Natl. Acad. Sci. USA 2006, 103, 15097-15102. [CrossRef] [PubMed] 
345. Grenfell, A.W.; Heald, R.; Strzelecka, M. Mitotic noncoding rna processing promotes kinetochore and spindle assembly in xenopus. J. Cell Biol. 2016, 214, 133-141. [CrossRef] [PubMed]

346. Liu, H.; Qu, Q.; Warrington, R.; Rice, A.; Cheng, N.; Yu, H. Mitotic transcription installs sgo1 at centromeres to coordinate chromosome segregation. Mol. Cell 2015, 59, 426-436. [CrossRef] [PubMed]

347. Gent, J.I.; Dawe, R.K. Rna as a structural and regulatory component of the centromere. Annu. Rev. Genet. 2012, 46, 443-453. [CrossRef] [PubMed]

348. Chan, F.L.; Marshall, O.J.; Saffery, R.; Kim, B.W.; Earle, E.; Choo, K.H.; Wong, L.H. Active transcription and essential role of rna polymerase ii at the centromere during mitosis. Proc. Natl. Acad. Sci. USA 2012, 109, 1979-1984. [CrossRef] [PubMed]

349. Prendergast, L.; Muller, S.; Liu, Y.; Huang, H.; Dingli, F.; Loew, D.; Vassias, I.; Patel, D.J.; Sullivan, K.F.; Almouzni, G. The cenp-t/-w complex is a binding partner of the histone chaperone fact. Genes Dev. 2016, 30, 1313-1326. [CrossRef] [PubMed]

350. Quenet, D.; Dalal, Y. A long non-coding rna is required for targeting centromeric protein a to the human centromere. eLife 2014, 3, e03254. [CrossRef] [PubMed]

351. Rosic, S.; Kohler, F.; Erhardt, S. Repetitive centromeric satellite rna is essential for kinetochore formation and cell division. J. Cell Biol. 2014, 207, 335-349. [CrossRef] [PubMed]

352. Catania, S.; Pidoux, A.L.; Allshire, R.C. Sequence features and transcriptional stalling within centromere DNA promote establishment of cenp-a chromatin. PLoS Genet. 2015, 11, e1004986. [CrossRef] [PubMed]

353. Schuh, M.; Lehner, C.F.; Heidmann, S. Incorporation of drosophila cid/cenp-a and cenp-c into centromeres during early embryonic anaphase. Curr. Biol. 2007, 17, 237-243. [CrossRef] [PubMed]

354. Dunleavy, E.M.; Almouzni, G.; Karpen, G.H. H3.3 is deposited at centromeres in s phase as a placeholder for newly assembled cenp-a in g(1) phase. Nucleus 2011, 2, 146-157. [CrossRef] [PubMed]

355. Pearson, C.G.; Yeh, E.; Gardner, M.; Odde, D.; Salmon, E.D.; Bloom, K. Stable kinetochore-microtubule attachment constrains centromere positioning in metaphase. Curr. Biol. 2004, 14, 1962-1967. [CrossRef] [PubMed]

356. Hayashi, T.; Fujita, Y.; Iwasaki, O.; Adachi, Y.; Takahashi, K.; Yanagida, M. Mis16 and mis18 are required for cenp-a loading and histone deacetylation at centromeres. Cell 2004, 118, 715-729. [CrossRef] [PubMed]

357. Fujita, Y.; Hayashi, T.; Kiyomitsu, T.; Toyoda, Y.; Kokubu, A.; Obuse, C.; Yanagida, M. Priming of centromere for cenp-a recruitment by human hmis18alpha, hmis18beta, and m18bp1. Dev. Cell 2007, 12, 17-30. [CrossRef] [PubMed]

358. Shiroiwa, Y.; Hayashi, T.; Fujita, Y.; Villar-Briones, A.; Ikai, N.; Takeda, K.; Ebe, M.; Yanagida, M. Mis17 is a regulatory module of the mis6-mal2-sim 4 centromere complex that is required for the recruitment of cenh3/cenp-a in fission yeast. PLoS ONE 2011, 6, e17761. [CrossRef] [PubMed]

359. Lee, B.C.; Lin, Z.; Yuen, K.W. Rbap46/48(lin-53) is required for holocentromere assembly in caenorhabditis elegans. Cell Rep. 2016, 14, 1819-1828. [CrossRef] [PubMed]

360. Subramanian, L.; Medina-Pritchard, B.; Barton, R.; Spiller, F.; Kulasegaran-Shylini, R.; Radaviciute, G.; Allshire, R.C.; Arockia Jeyaprakash, A. Centromere localization and function of mis18 requires yippee-like domain-mediated oligomerization. EMBO Rep. 2016, 17, 496-507. [CrossRef] [PubMed]

361. Nardi, I.K.; Zasadzinska, E.; Stellfox, M.E.; Knippler, C.M.; Foltz, D.R. Licensing of centromeric chromatin assembly through the mis18alpha-mis18beta heterotetramer. Mol. Cell 2016, 61, 774-787. [CrossRef] [PubMed]

362. Maddox, P.S.; Hyndman, F.; Monen, J.; Oegema, K.; Desai, A. Functional genomics identifies a myb domain-containing protein family required for assembly of cenp-a chromatin. J. Cell Biol. 2007, 176, 757-763. [CrossRef] [PubMed]

363. Pan, D.; Klare, K.; Petrovic, A.; Take, A.; Walstein, K.; Singh, P.; Rondelet, A.; Bird, A.W.; Musacchio, A. Cdk-regulated dimerization of $\mathrm{m} 18 \mathrm{bp} 1$ on a mis18 hexamer is necessary for cenp-a loading. eLife 2017, 6. [CrossRef] [PubMed]

364. Hayashi, T.; Ebe, M.; Nagao, K.; Kokubu, A.; Sajiki, K.; Yanagida, M. Schizosaccharomyces pombe centromere protein mis19 links mis16 and mis18 to recruit cenp-a through interacting with nmd factors and the swi/snf complex. Genes Cells 2014, 19, 541-554. [CrossRef] [PubMed]

365. Subramanian, L.; Toda, N.R.; Rappsilber, J.; Allshire, R.C. Eic1 links mis18 with the ccan/mis6/ctf19 complex to promote cenp-a assembly. Open Biol. 2014, 4. [CrossRef] [PubMed] 
366. Dunleavy, E.M.; Roche, D.; Tagami, H.; Lacoste, N.; Ray-Gallet, D.; Nakamura, Y.; Daigo, Y.; Nakatani, Y.; Almouzni-Pettinotti, G. Hjurp is a cell-cycle-dependent maintenance and deposition factor of cenp-a at centromeres. Cell 2009, 137, 485-497. [CrossRef] [PubMed]

367. Foltz, D.R.; Jansen, L.E.; Bailey, A.O.; Yates, J.R., 3rd; Bassett, E.A.; Wood, S.; Black, B.E.; Cleveland, D.W. Centromere-specific assembly of cenp-a nucleosomes is mediated by hjurp. Cell 2009, 137, 472-484. [CrossRef] [PubMed]

368. Bernad, R.; Sanchez, P.; Rivera, T.; Rodriguez-Corsino, M.; Boyarchuk, E.; Vassias, I.; Ray-Gallet, D.; Arnaoutov, A.; Dasso, M.; Almouzni, G.; et al. Xenopus hjurp and condensin ii are required for cenp-a assembly. J. Cell Biol. 2011, 192, 569-582. [CrossRef] [PubMed]

369. Aravind, L.; Iyer, L.M.; Wu, C. Domain architectures of the $\mathrm{scm} 3 p$ protein provide insights into centromere function and evolution. Cell Cycle 2007, 6, 2511-2515. [CrossRef] [PubMed]

370. Stoler, S.; Rogers, K.; Weitze, S.; Morey, L.; Fitzgerald-Hayes, M.; Baker, R.E. Scm3, an essential saccharomyces cerevisiae centromere protein required for $\mathrm{g} 2 / \mathrm{m}$ progression and cse4 localization. Proc. Natl. Acad. Sci. USA 2007, 104, 10571-10576. [CrossRef] [PubMed]

371. Camahort, R.; Li, B.; Florens, L.; Swanson, S.K.; Washburn, M.P.; Gerton, J.L. Scm3 is essential to recruit the histone h3 variant cse4 to centromeres and to maintain a functional kinetochore. Mol. Cell 2007, 26, 853-865. [CrossRef] [PubMed]

372. Pidoux, A.L.; Choi, E.S.; Abbott, J.K.; Liu, X.; Kagansky, A.; Castillo, A.G.; Hamilton, G.L.; Richardson, W.; Rappsilber, J.; He, X.; et al. Fission yeast scm3: A cenp-a receptor required for integrity of subkinetochore chromatin. Mol. Cell 2009, 33, 299-311. [CrossRef] [PubMed]

373. Mizuguchi, G.; Xiao, H.; Wisniewski, J.; Smith, M.M.; Wu, C. Nonhistone scm3 and histones cenh3-h4 assemble the core of centromere-specific nucleosomes. Cell 2007, 129, 1153-1164. [CrossRef] [PubMed]

374. Chen, C.C.; Dechassa, M.L.; Bettini, E.; Ledoux, M.B.; Belisario, C.; Heun, P.; Luger, K.; Mellone, B.G. Cal1 is the drosophila cenp-a assembly factor. J. Cell Biol. 2014, 204, 313-329. [CrossRef] [PubMed]

375. Williams, J.S.; Hayashi, T.; Yanagida, M.; Russell, P. Fission yeast scm3 mediates stable assembly of cnp1/cenp-a into centromeric chromatin. Mol. Cell 2009, 33, 287-298. [CrossRef] [PubMed]

376. Sanchez-Pulido, L.; Pidoux, A.L.; Ponting, C.P.; Allshire, R.C. Common ancestry of the cenp-a chaperones scm3 and hjurp. Cell 2009, 137, 1173-1174. [CrossRef] [PubMed]

377. Erhardt, S.; Mellone, B.G.; Betts, C.M.; Zhang, W.; Karpen, G.H.; Straight, A.F. Genome-wide analysis reveals a cell cycle-dependent mechanism controlling centromere propagation. J. Cell Biol. 2008, 183, 805-818. [CrossRef] [PubMed]

378. Schittenhelm, R.B.; Althoff, F.; Heidmann, S.; Lehner, C.F. Detrimental incorporation of excess cenp-a/cid and cenp-c into drosophila centromeres is prevented by limiting amounts of the bridging factor cal1. J. Cell Sci. 2010, 123, 3768-3779. [CrossRef] [PubMed]

379. Rosin, L.; Mellone, B.G. Co-evolving cenp-a and cal1 domains mediate centromeric cenp-a deposition across drosophila species. Dev. Cell 2016, 37, 136-147. [CrossRef] [PubMed]

380. Zasadzinska, E.; Barnhart-Dailey, M.C.; Kuich, P.H.; Foltz, D.R. Dimerization of the cenp-a assembly factor hjurp is required for centromeric nucleosome deposition. EMBO J. 2013, 32, 2113-2124. [CrossRef] [PubMed]

381. Shuaib, M.; Ouararhni, K.; Dimitrov, S.; Hamiche, A. Hjurp binds cenp-a via a highly conserved n-terminal domain and mediates its deposition at centromeres. Proc. Natl. Acad. Sci. USA 2010, 107, 1349-1354. [CrossRef] [PubMed]

382. Cho, U.S.; Harrison, S.C. Recognition of the centromere-specific histone cse 4 by the chaperone scm3. Proc. Natl. Acad. Sci. USA 2011, 108, 9367-9371. [CrossRef] [PubMed]

383. Hu, H.; Liu, Y.; Wang, M.; Fang, J.; Huang, H.; Yang, N.; Li, Y.; Wang, J.; Yao, X.; Shi, Y.; et al. Structure of a cenp-a-histone h4 heterodimer in complex with chaperone hjurp. Genes Dev. 2011, 25, 901-906. [CrossRef] [PubMed]

384. Zhou, Z.; Feng, H.; Zhou, B.R.; Ghirlando, R.; Hu, K.; Zwolak, A.; Miller Jenkins, L.M.; Xiao, H.; Tjandra, N.; $\mathrm{Wu}, \mathrm{C}$; et al. Structural basis for recognition of centromere histone variant cenh3 by the chaperone $\mathrm{scm} 3$. Nature 2011, 472, 234-237. [CrossRef] [PubMed]

385. Perpelescu, M.; Hori, T.; Toyoda, A.; Misu, S.; Monma, N.; Ikeo, K.; Obuse, C.; Fujiyama, A.; Fukagawa, T. Hjurp is involved in the expansion of centromeric chromatin. Mol. Biol. Cell 2015, 26, 2742-2754. [CrossRef] [PubMed] 
386. Wang, J.; Liu, X.; Dou, Z.; Chen, L.; Jiang, H.; Fu, C.; Fu, G.; Liu, D.; Zhang, J.; Zhu, T.; et al. Mitotic regulator mis18beta interacts with and specifies the centromeric assembly of molecular chaperone holliday junction recognition protein (hjurp). J. Biol. Chem. 2014, 289, 8326-8336. [CrossRef] [PubMed]

387. Moree, B.; Meyer, C.B.; Fuller, C.J.; Straight, A.F. Cenp-c recruits $\mathrm{m} 18 \mathrm{bp} 1$ to centromeres to promote cenp-a chromatin assembly. J. Cell Biol. 2011, 194, 855-871. [CrossRef] [PubMed]

388. Stellfox, M.E.; Nardi, I.K.; Knippler, C.M.; Foltz, D.R. Differential binding partners of the mis18alpha/beta yippee domains regulate mis18 complex recruitment to centromeres. Cell Rep. 2016, 15, 2127-2135. [CrossRef] [PubMed]

389. Dambacher, S.; Deng, W.; Hahn, M.; Sadic, D.; Frohlich, J.; Nuber, A.; Hoischen, C.; Diekmann, S.; Leonhardt, H.; Schotta, G. Cenp-c facilitates the recruitment of m18bp1 to centromeric chromatin. Nucleus 2012, 3, 101-110. [CrossRef] [PubMed]

390. Takahashi, K.; Chen, E.S.; Yanagida, M. Requirement of mis6 centromere connector for localizing a cenp-a-like protein in fission yeast. Science 2000, 288, 2215-2219. [CrossRef] [PubMed]

391. Shono, N.; Ohzeki, J.; Otake, K.; Martins, N.M.; Nagase, T.; Kimura, H.; Larionov, V.; Earnshaw, W.C.; Masumoto, H. Cenp-c and cenp-i are key connecting factors for kinetochore and cenp-a assembly. J. Cell Sci. 2015, 128, 4572-4587. [CrossRef] [PubMed]

392. Silva, M.C.; Bodor, D.L.; Stellfox, M.E.; Martins, N.M.; Hochegger, H.; Foltz, D.R.; Jansen, L.E. Cdk activity couples epigenetic centromere inheritance to cell cycle progression. Dev. Cell 2012, 22, 52-63. [CrossRef] [PubMed]

393. Yu, Z.; Zhou, X.; Wang, W.; Deng, W.; Fang, J.; Hu, H.; Wang, Z.; Li, S.; Cui, L.; Shen, J.; et al. Dynamic phosphorylation of cenp-a at ser68 orchestrates its cell-cycle-dependent deposition at centromeres. Dev. Cell 2015, 32, 68-81. [CrossRef] [PubMed]

394. Muller, S.; Montes de Oca, R.; Lacoste, N.; Dingli, F.; Loew, D.; Almouzni, G. Phosphorylation and DNA binding of hjurp determine its centromeric recruitment and function in cenh3(cenp-a) loading. Cell Rep. 2014, 8, 190-203. [CrossRef] [PubMed]

395. McKinley, K.L.; Cheeseman, I.M. Polo-like kinase 1 licenses cenp-a deposition at centromeres. Cell 2014, 158, 397-411. [CrossRef] [PubMed]

396. Stankovic, A.; Guo, L.Y.; Mata, J.F.; Bodor, D.L.; Cao, X.J.; Bailey, A.O.; Shabanowitz, J.; Hunt, D.F.; Garcia, B.A.; Black, B.E.; et al. A dual inhibitory mechanism sufficient to maintain cell-cycle-restricted cenp-a assembly. Mol. Cell 2016. [CrossRef] [PubMed]

397. Miell, M.D.; Straight, A.F. Regulating the timing of cenp-a nucleosome assembly by phosphorylation. Dev. Cell 2015, 32, 1-2. [CrossRef] [PubMed]

398. Deyter, G.M.; Biggins, S. The fact complex interacts with the e3 ubiquitin ligase psh1 to prevent ectopic localization of cenp-a. Genes Dev. 2014, 28, 1815-1826. [CrossRef] [PubMed]

399. Chen, C.C.; Bowers, S.; Lipinszki, Z.; Palladino, J.; Trusiak, S.; Bettini, E.; Rosin, L.; Przewloka, M.R.; Glover, D.M.; O'Neill, R.J.; et al. Establishment of centromeric chromatin by the cenp-a assembly factor cal1 requires fact-mediated transcription. Dev. Cell 2015, 34, 73-84. [CrossRef] [PubMed]

400. Lagana, A.; Dorn, J.F.; De Rop, V.; Ladouceur, A.M.; Maddox, A.S.; Maddox, P.S. A small gtpase molecular switch regulates epigenetic centromere maintenance by stabilizing newly incorporated cenp-a. Nat. Cell Biol. 2010, 12, 1186-1193. [CrossRef] [PubMed]

401. Perpelescu, M.; Nozaki, N.; Obuse, C.; Yang, H.; Yoda, K. Active establishment of centromeric cenp-a chromatin by rsf complex. J. Cell Biol. 2009, 185, 397-407. [CrossRef] [PubMed]

402. Boltengagen, M.; Huang, A.; Boltengagen, A.; Trixl, L.; Lindner, H.; Kremser, L.; Offterdinger, M.; Lusser, A. A novel role for the histone acetyltransferase hat1 in the cenp-a/cid assembly pathway in Drosophila melanogaster. Nucleic Acids Res. 2016, 44, 2145-2159. [CrossRef] [PubMed]

403. Jaramillo-Lambert, A.; Hao, J.; Xiao, H.; Li, Y.; Han, Z.; Zhu, W. Acidic nucleoplasmic DNA-binding protein (and-1) controls chromosome congression by regulating the assembly of centromere protein a (cenp-a) at centromeres. J. Biol. Chem. 2013, 288, 1480-1488. [CrossRef] [PubMed]

404. Choi, E.S.; Stralfors, A.; Catania, S.; Castillo, A.G.; Svensson, J.P.; Pidoux, A.L.; Ekwall, K.; Allshire, R.C. Factors that promote $\mathrm{h} 3$ chromatin integrity during transcription prevent promiscuous deposition of cenp-a(cnp1) in fission yeast. PLoS Genet. 2012, 8, e1002985. [CrossRef] [PubMed]

405. Mamnun, Y.M.; Katayama, S.; Toda, T. Fission yeast mcl1 interacts with scf(pof3) and is required for centromere formation. Biochem. Biophys. Res. Commun. 2006, 350, 125-130. [CrossRef] [PubMed] 
406. Gopalakrishnan, S.; Sullivan, B.A.; Trazzi, S.; Della Valle, G.; Robertson, K.D. Dnmt3b interacts with constitutive centromere protein cenp-c to modulate DNA methylation and the histone code at centromeric regions. Hum. Mol. Genet. 2009, 18, 3178-3193. [CrossRef] [PubMed]

407. Kim, I.S.; Lee, M.; Park, K.C.; Jeon, Y.; Park, J.H.; Hwang, E.J.; Jeon, T.I.; Ko, S.; Lee, H.; Baek, S.H.; et al. Roles of mis18alpha in epigenetic regulation of centromeric chromatin and cenp-a loading. Mol. Cell 2012, 46, 260-273. [CrossRef] [PubMed]

408. Vernarecci, S.; Ornaghi, P.; Bagu, A.; Cundari, E.; Ballario, P.; Filetici, P. Gen5p plays an important role in centromere kinetochore function in budding yeast. Mol. Cell. Biol. 2008, 28, 988-996. [CrossRef] [PubMed]

409. Ohzeki, J.; Shono, N.; Otake, K.; Martins, N.M.; Kugou, K.; Kimura, H.; Nagase, T.; Larionov, V.; Earnshaw, W.C.; Masumoto, H. Kat7/hbo1/myst2 regulates cenp-a chromatin assembly by antagonizing suv39h1-mediated centromere inactivation. Dev. Cell 2016, 37, 413-427. [CrossRef] [PubMed]

410. Bergmann, J.H.; Rodriguez, M.G.; Martins, N.M.; Kimura, H.; Kelly, D.A.; Masumoto, H.; Larionov, V.; Jansen, L.E.; Earnshaw, W.C. Epigenetic engineering shows h3k4me2 is required for hjurp targeting and cenp-a assembly on a synthetic human kinetochore. EMBO J. 2011, 30, 328-340. [CrossRef] [PubMed]

411. Ohzeki, J.; Bergmann, J.H.; Kouprina, N.; Noskov, V.N.; Nakano, M.; Kimura, H.; Earnshaw, W.C.; Larionov, V.; Masumoto, H. Breaking the hac barrier: Histone h3k9 acetyl/methyl balance regulates cenp-a assembly. EMBO J. 2012, 31, 2391-2402. [CrossRef] [PubMed]

412. Raychaudhuri, N.; Dubruille, R.; Orsi, G.A.; Bagheri, H.C.; Loppin, B.; Lehner, C.F. Transgenerational propagation and quantitative maintenance of paternal centromeres depends on cid/cenp-a presence in drosophila sperm. PLoS Biol. 2012, 10, e1001434. [CrossRef] [PubMed]

413. Ross, J.E.; Woodlief, K.S.; Sullivan, B.A. Inheritance of the cenp-a chromatin domain is spatially and temporally constrained at human centromeres. Epigenet. Chromatin 2016, 9. [CrossRef] [PubMed]

414. Mizuguchi, G.; Shen, X.; Landry, J.; Wu, W.H.; Sen, S.; Wu, C. Atp-driven exchange of histone h2az variant catalyzed by swr1 chromatin remodeling complex. Science 2004, 303, 343-348. [CrossRef] [PubMed]

415. Podhraski, V.; Campo-Fernandez, B.; Worle, H.; Piatti, P.; Niederegger, H.; Bock, G.; Fyodorov, D.V.; Lusser, A. Cenh3/cid incorporation is not dependent on the chromatin assembly factor chd1 in drosophila. PLoS ONE 2010, 5, e10120. [CrossRef] [PubMed]

416. Thompson, J.D.; Sylvester, J.E.; Gonzalez, I.L.; Costanzi, C.C.; Gillespie, D. Definition of a second dimeric subfamily of human alpha satellite DNA. Nucleic Acids Res. 1989, 17, 2769-2782. [CrossRef] [PubMed]

417. Cellamare, A.; Catacchio, C.R.; Alkan, C.; Giannuzzi, G.; Antonacci, F.; Cardone, M.F.; Della Valle, G.; Malig, M.; Rocchi, M.; Eichler, E.E.; et al. New insights into centromere organization and evolution from the white-cheeked gibbon and marmoset. Mol. Biol. Evol. 2009, 26, 1889-1900. [CrossRef] [PubMed]

418. Camahort, R.; Shivaraju, M.; Mattingly, M.; Li, B.; Nakanishi, S.; Zhu, D.; Shilatifard, A.; Workman, J.L.; Gerton, J.L. Cse4 is part of an octameric nucleosome in budding yeast. Mol. Cell 2009, 35, 794-805. [CrossRef] [PubMed]

419. Akiyoshi, B.; Gull, K. Discovery of unconventional kinetochores in kinetoplastids. Cell 2014, 156, 1247-1258. [CrossRef] [PubMed]

420. D'Archivio, S.; Wickstead, B. Trypanosome outer kinetochore proteins suggest conservation of chromosome segregation machinery across eukaryotes. J. Cell Biol. 2016. [CrossRef] [PubMed]

421. Monen, J.; Maddox, P.S.; Hyndman, F.; Oegema, K.; Desai, A. Differential role of cenp-a in the segregation of holocentric c. Elegans chromosomes during meiosis and mitosis. Nat. Cell Biol. 2005, 7, 1248-1255. [CrossRef] [PubMed]

(C) 2017 by the authors; licensee MDPI, Basel, Switzerland. This article is an open access article distributed under the terms and conditions of the Creative Commons Attribution (CC BY) license (http:/ / creativecommons.org/licenses/by/4.0/). 